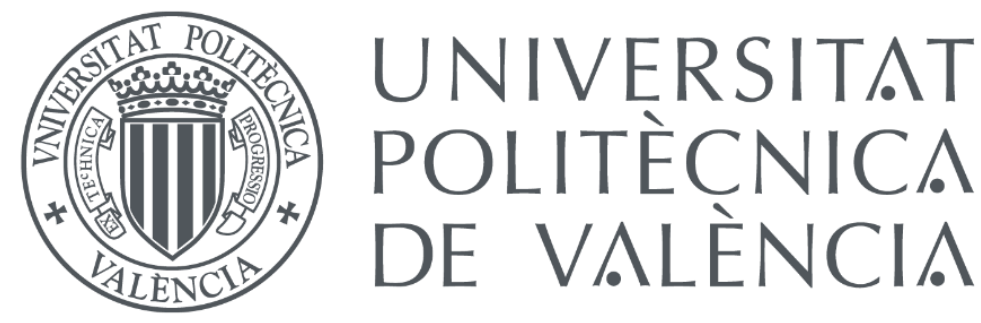

Departamento de Economía y Ciencias Sociales

Programa de Doctorado en Administración y Dirección de Empresas

\title{
Effectuation, domestic network strength, institutional voids and accelerated internationalization: Evidence from Latin American SMEs
}

\section{Tesis doctoral}

Presentado por:

Juan Manuel Gil Barragán

Dirigida por:

Francisco Mas Verdú

José Antonio Belso Martínez

Valencia, julio de 2020 


\section{Agradecimientos}

Mi primer agradecimiento lo dirijo a Dios, a la Virgen María y a mi familia. A Dios, porque durante el desarrollo de esta tesis doctoral, pude experimentar de primera mano su providencia con el tiempo. En estos tres años, sentí cómo Dios multiplicó el tiempo y me dio la gracia de desarrollar la tesis, mientras le dedicaba tiempo a Él, a mi esposa, a mi hijo que nació durante este periodo y mi trabajo. A la Virgen María, porque este proceso se lo consagré a ella y sentí su maternal compañía. A mi esposa Jennifer Álvarez y mis hijos Josemaría, Juan Martín y José, porque su alegría, amor y apoyo, le dan sentido a mi vida. Con ellos siento que vivo el cielo en la tierra.

En segundo lugar, quiero expresar mi más profundo agradecimiento a mis directores Francisco Mas Verdú y José Antonio Belso Martínez. Creo que, así como Dios multiplicó mi tiempo, también me regaló dos directores excepcionales. Admiro la pedagogía con la que se llevó el proceso, la pertinencia de las enseñanzas y consejos, la sabiduría y experiencia que tienen, el tiempo que me dedicaron y su calidad humana. Sin ellos, no habría podido avanzar y culminar este proceso. Me siento muy afortunado de haber tenido estos directores. 


\section{Summary}

This thesis investigates the type of domestic network strength and type of decisionmaking logic as causal conditions for achieving accelerated internationalisation in small and medium enterprises (SMEs) located in context of institutional voids. Furthermore, this dissertation explore the micro-mechanisms that connect the impact institutional voids, effectual networking and networks strength on the accelerated internationalisation of SMEs from Latin America.

The existing literature shows discrepancies among researchers about the individual effect of networks strength, decision-making logic and institutional voids on accelerated internationalisation. Moreover, scholars argue that accelerated internationalization is a complex phenomenon that should be studied by identifying the complex relations among variables. However, it seems that no studies have explore this complex interaction and the connection among these factors. Consequently, researchers advise to increase the investigation about the effects of these variables on the accelerated internationalisation of SMEs. They have also suggest to incorporate effectuation and institutional voids to clarify these discrepancies. On this matter, researches warn that research on effectuation and internationalization is an emerging scientific field that lacks conceptual clarity. Recent studies also advice to move beyond foreign networks to explore the role of domestic networks on accelerated internationalization. Finally, there have been calls

to advance research on Latin America that usually has been neglected in the existing literature.

Therefore, this thesis aims to provide an approach based on three different methodologies: First, a bibliometric analysis to contribute to classify the literature of effectuation and internationalization, and identify its structure and key trends. Second, a fuzzy-set qualitative comparative analysis (fsQCA) to investigates which causal conditions contribute to accelerated internationalization among 33 contrarian cases (21 from Colombia and 12 from Peru) of SMEs from context with institutional voids. Results show that the combination of weak domestic ties and effectuation 
logic accelerated the internationalization of SMEs with fewer resource constraints. In contrast, strong domestic ties and causation behaviour lead to accelerated internationalization of SMEs with greater resource constraints. Based on these findings, an integrative model that linked the causal configurations to reach accelerated internationalization is developed.

Finally, an ordered logistic regression of 2.987 SMEs from Argentina, Colombia and Peru, to examine the micro-mechanisms that connect institutional voids, effectual networking, networks strength and location on the accelerated internationalisation of SMEs from Latin America. Results show that (1) rural cities, instead of first- and second-tier cities, accelerated the internationalization process of the firm. (2) Institutional voids, effectual networks and strong local ties increase the likelihood of accelerated internationalization. Finally, (3) we found a robust and high interaction effect between effectual networking, significant institutional voids, strong local ties, size of the firm and rural cities location on accelerated internationalization. Based on the findings, a conceptual model is presented. 


\section{Resumen}

A partir del tipo de las relaciones de la red de contactos locales y la lógica en la toma de decisiones, esta tesis investiga las condiciones causales necesarias para que las pequeñas y medianas empresas (Pymes) que están situadas en contextos caracterizados por vacíos institucionales, logren tener una internacionalización acelerada. Adicionalmente, esta disertación explora los micro-mecanismos que conectan los vacíos institucionales, las redes efectúales y el tipo de relaciones (fuertes o débiles) con la internacionalización acelerada que presentan las Pymes de Latinoamérica.

La literatura existente muestra discrepancias sobre el efecto individual que tienen las relaciones de la red de contactos locales, la lógica en la toma de decisiones y los vacíos institucionales sobre la internacionalización acelerada. Así mismo, los investigadores argumentan que este es un fenómeno complejo y por lo tanto, debería analizarse identificando las relaciones complejas que puedan existir entre las variables. Sin embargo, al parecer, ningún estudio ha explorado esta compleja interacción y la conexión que existe entre estos factores. En consecuencia, diversos estudios aconsejan ahondar en la investigación sobre los efectos que pueden tener estas variables sobre la internacionalización acelerada de las Pymes. Adicionalmente, han sugerido incorporar la efectuación y los vacíos institucionales como variables que pueden contribuir a aclarar estas discrepancias. Sobre este asunto, los investigadores advierten que la efectuación y la internacionalización, es un campo científico emergente que carece de claridad conceptual. Estudios recientes también aconsejan que la investigación vaya más allá de las redes internacionales para explorar el papel de las redes locales sobre la internacionalización acelerada. Finalmente, ha habido diversos llamados para avanzar en la investigación sobre América Latina, que es una región que generalmente se ha descuidado en la investigación existente. 
Consecuentemente, esta tesis tiene como objetivo desarrollar la investigación bajo tres metodologías diferentes: Primero, a través de un análisis bibliométrico que permite contribuir con la clasificación de la literatura, la identificación de la estructura y las tendencias de la investigación sobre la efectuación y la internacionalización de las Pymes. En segundo lugar, a través de un Análisis Cualitativo Comparativo (fsQCA por sus siglas en inglés) que contribuye a identificar las condiciones causales que favorecen la internacionalización acelerada de 33 casos contrarios (21 de Colombia y 12 de Perú) de Pymes localizadas en contextos con vacíos institucionales. El resultado de este estudio demuestra que la combinación de redes locales con lazos débiles y la lógica de la efectuación, contribuyen con la internacionalización acelerada de las Pymes que tienen menores limitaciones en sus recursos. En contraste, las redes locales con lazos fuertes y la lógica de causación, asisten la internacionalización acelerada de las Pymes que tienen una mayor limitación en sus recursos. En base a estos hallazgos, se desarrolla un modelo integrador que vincula las configuraciones causales que permiten obtener una internacionalización acelerada.

Finalmente, a través de una regresión logística ordenada de 2.987 Pymes de Argentina, Colombia y Perú, se examinan los micro-mecanismos que conectan los vacíos institucionales, las redes efectúales, el tipo de relación con las redes de contacto y la localización con la internacionalización acelerada de las Pymes de Latinoamérica. Los resultados demuestran que las ciudades rurales, en lugar de las ciudades de primer y segundo nivel, aceleran la internacionalización de las empresas. Adicionalmente, los altos niveles de vacíos institucionales, las redes efectúales, las redes locales de lazos fuertes y localizarse en el área rural, aumentan la probabilidad de una internacionalización acelerada. Además, la investigación evidencia que existe un efecto de interacción fuerte y robusta entre las redes locales de lazos fuertes y los altos niveles de vacíos institucionales sobre la internacionalización acelerada. Este mismo efecto de interacción se da entre las redes locales de lazos fuertes y las redes efectúales y las redes locales de lazos fuertes con la localización en áreas rurales. Basados en estos resultados, se propone un modelo conceptual. 


\section{Resum}

A partir de la mena de les relacions de la xarxa de contactes locals i la lògica en la presa de decisions, aquesta tesi investiga les condicions causals necessàries perquè les petites i mitjanes empreses (Pimes) que estan situades en contextos caracteritzats per buits institucionals, aconseguisquen tindre una internacionalització accelerada. Addicionalment, aquesta dissertació explora els micro-mecanismes que connecten els buits institucionals, les xarxes efectua'ls i el tipus de relacions (fortes o febles) amb la internacionalització accelerada que presenten les Pimes de Llatinoamèrica.

La literatura existent mostra discrepàncies sobre l'efecte individual que tenen les relacions de la xarxa de contactes locals, la lògica en la presa de decisions i els buits institucionals sobre la internacionalització accelerada. Així mateix, els investigadors argumenten que aquest és un fenomen complex i per tant, hauria d'analitzar-se identificant les relacions complexes que puguen existir entre les variables. No obstant això, pel que sembla, cap estudi ha explorat aquesta complexa interacció i la connexió que existeix entre aquests factors. En conseqüència, diversos estudis aconsellen aprofundir en la investigació sobre els efectes que poden tindre aquestes variables sobre la internacionalització accelerada de les Pimes. Addicionalment, han suggerit incorporar l'efectuació i els buits institucionals com a variables que poden contribuir a aclarir aquestes discrepàncies. Sobre aquest assumpte, els investigadors adverteixen que l'efectuació i la internacionalització, és un camp científic emergent que manca de claredat conceptual. Estudis recents també aconsellen que la investigació vaja més enllà de les xarxes internacionals per a explorar el paper de les xarxes locals sobre la internacionalització accelerada. Finalment, hi ha hagut diverses demandes per a avançar en la investigació sobre Amèrica Llatina, que és una regió que generalment s'ha desatès en la investigació existent.

Conseqüentment, aquesta tesi té com a objectiu desenvolupar la investigació sota tres metodologies diferents: Primer, a través d'una anàlisi bibliomètrica que permet 
contribuir amb la classificació de la literatura, la identificació de l'estructura i les tendències de la investigació sobre l'efectuació i la internacionalització de les Pimes. En segon lloc, a través d'una Anàlisi Qualitativa Comparativa ( ${ }^{*} f s Q C A$ per les seues sigles en anglés) que contribueix a identificar les condicions causals que afavoreixen la internacionalització accelerada de 33 casos contraris (21 de Colòmbia i 12 del Perú) de Pimes localitzades en contextos amb buits institucionals. El resultat d'aquest estudi demostra que la combinació de xarxes locals amb llaços febles i la lògica de l'efectuació, contribueixen amb la internacionalització accelerada de les Pimes que tenen menors limitacions en els seus recursos. En contrast, les xarxes locals amb llaços forts i la lògica de causació, assisteixen la internacionalització accelerada de les Pimes que tenen una major limitació en els seus recursos. Sobre la base d'aquests resultats, es desenvolupa un model integrador que vincula les configuracions causals que permeten obtindre una internacionalització accelerada.

Finalment, a través d'una regressió logística ordenada de 2.987 Pimes de l'Argentina, Colòmbia i el Perú, s'examinen els micro-mecanismes que connecten els buits institucionals, les xarxes efectuals, el tipus de relació amb les xarxes de contacte i la localització amb la internacionalització accelerada de les Pimes de Llatinoamèrica. Els resultats demostren que els alts nivells de buits institucionals, les xarxes efectuals, les xarxes locals de llaços forts i localitzar-se en l'àrea rural, augmenten la probabilitat d'una internacionalització accelerada. A més, la investigació evidencia que existeix un efecte d'interacció forta i robusta entre les xarxes locals de llaços forts $\mathrm{i}$ els alts nivells de buits institucionals sobre la internacionalització accelerada. Aquest mateix efecte d'interacció es dona entre les xarxes locals de llaços forts i les xarxes efectuals i les xarxes locals de llaços forts amb la localització en àrees rural. Basats en aquests resultats, es proposa un model conceptual. 


\section{Table of contents}

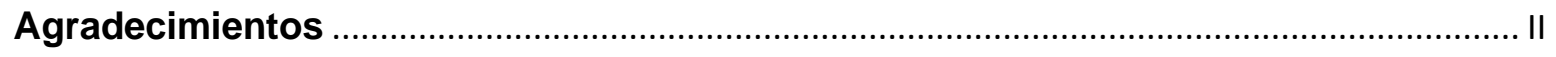

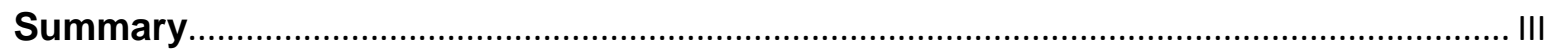

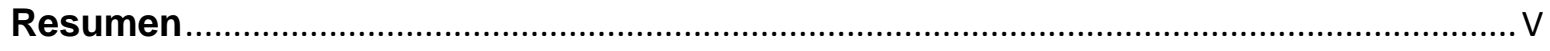

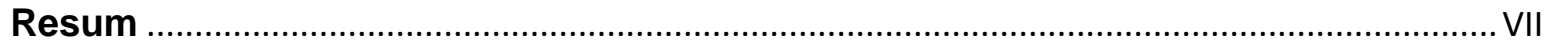

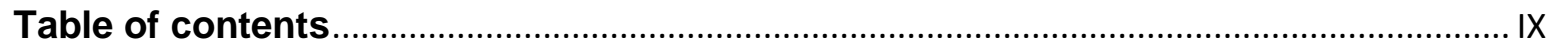

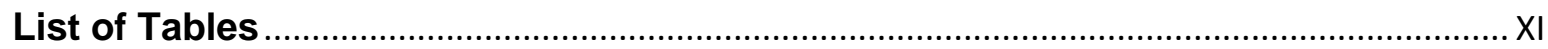

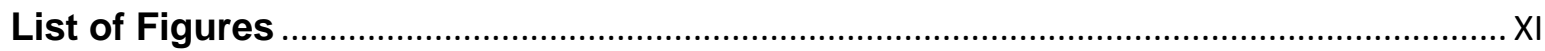

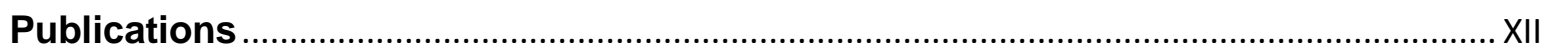

Chapter One - Introduction and objectives ………………........................................... 1

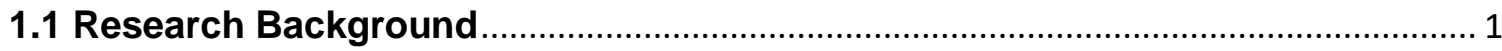

1.2 Research problem and objectives of the thesis ................................................. 4

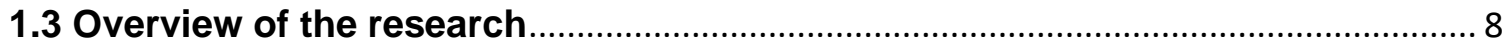

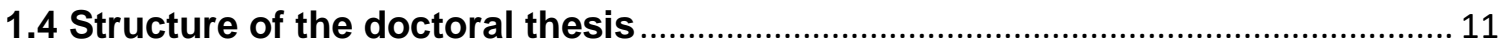

Chapter Two - Bibliometric analysis of the theory of effectuation and the internationalisation of small and medium-sized enterprises ....................................... 14

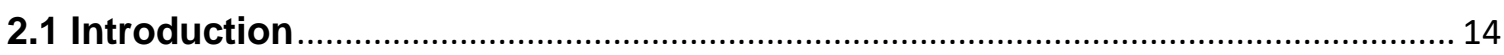

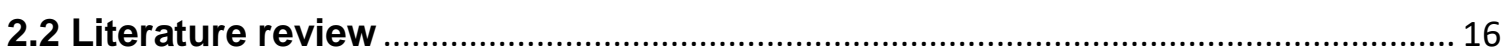

2.2.1 Theory of effectuation and the internationalisation of SMEs ....................... 16

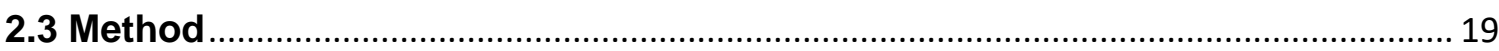

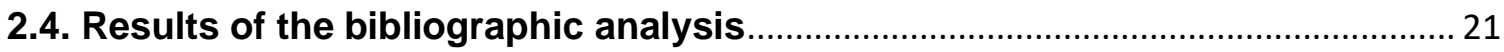

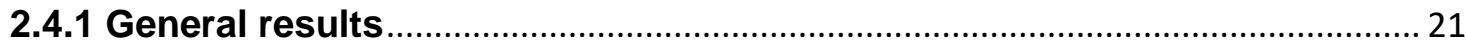

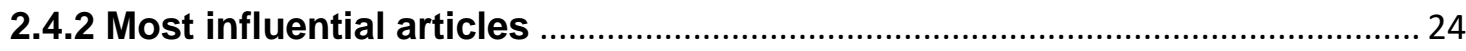

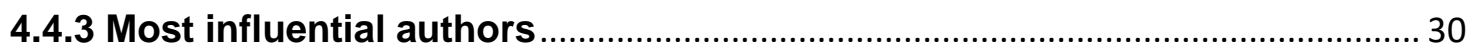

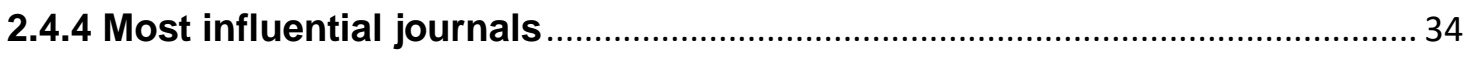

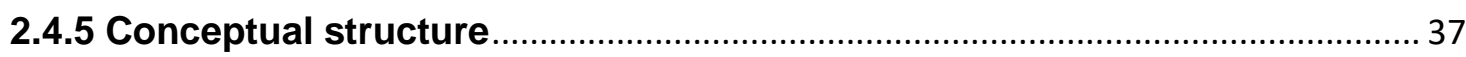

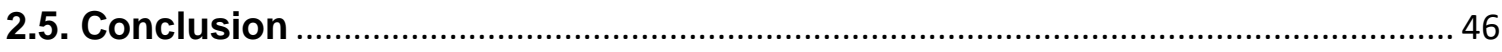

2.6. Limitations and research opportunities ……………......................................... 47

Chapter Three - When do domestic networks cause accelerated internationalisation under different decision-making logic? Evidence from contexts with institutional voids.

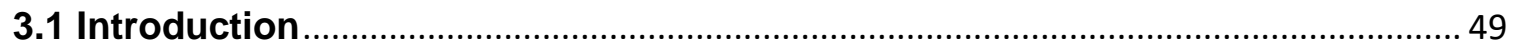

3.2 Theoretical framework ...................................................................................... 54 


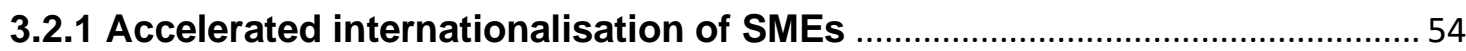

3.2.2 Accelerated Internationalisation: Foreign vs. Domestic Networks.............. 56

3.2.3 Decision-making logic causing accelerated internationalisation:

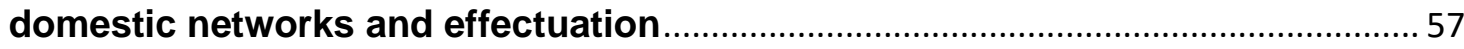

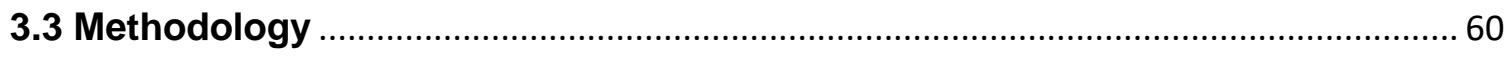

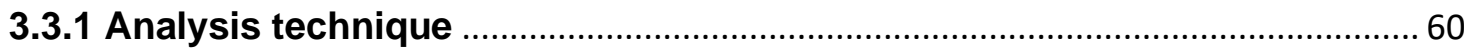

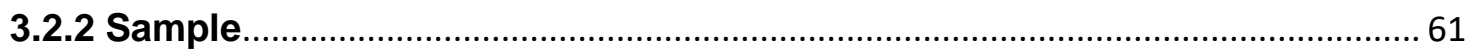

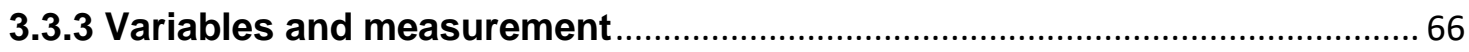

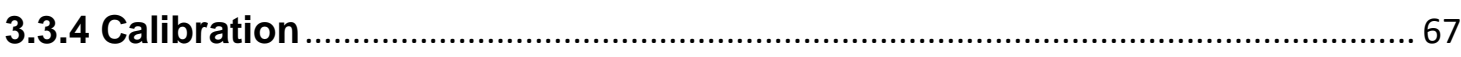

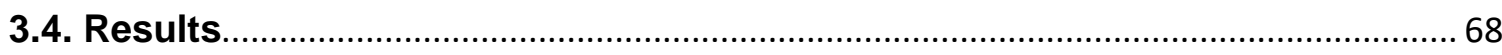

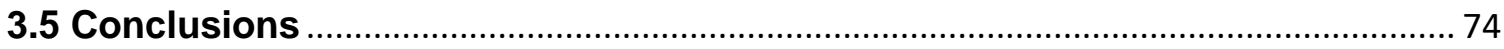

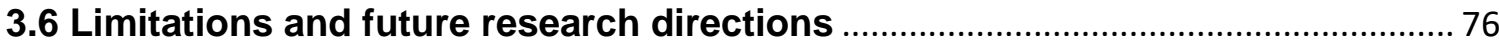

Chapter four- The fast lane of internationalisation of Latin American SMEs: Effectual networks, institutional voids and location effects ....................................................... 78

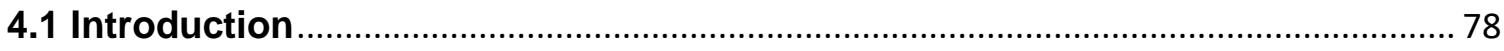

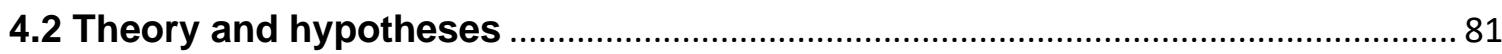

4.2.1 Spatial dimension, institutional voids and accelerated internationalization

4.2.2 Uncertainty, effectual networks and accelerated internationalization ......... 83

4.2.3 Uncertainty, network strength and accelerated internationalization ........... 86

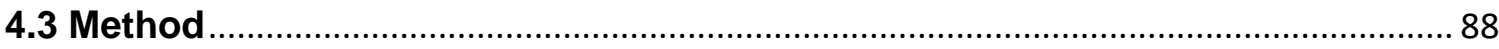

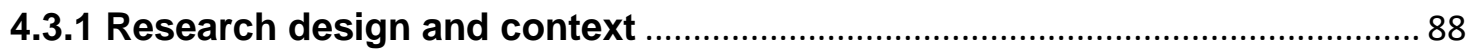

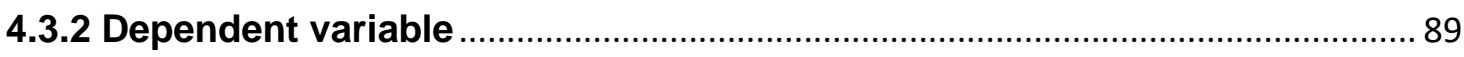

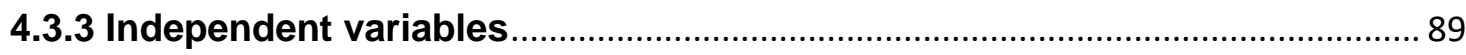

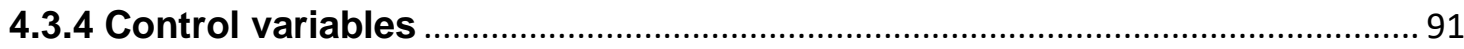

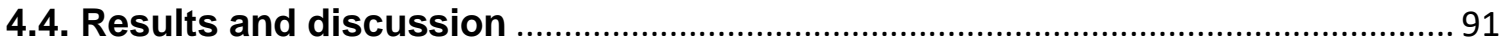

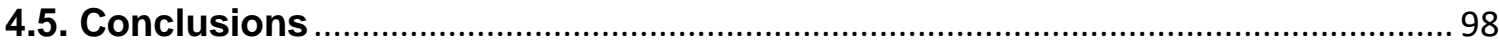

Chapter five - General discussion of the research results ....................................... 101

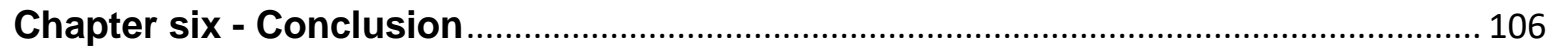

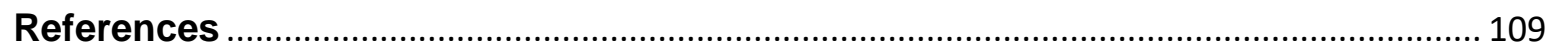




\section{List of Tables}

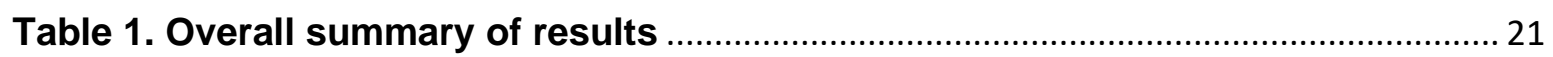

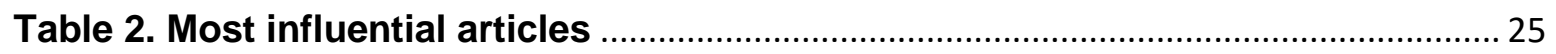

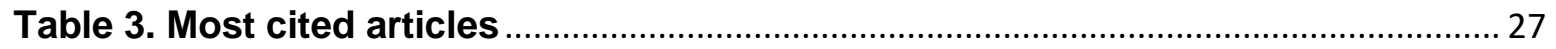

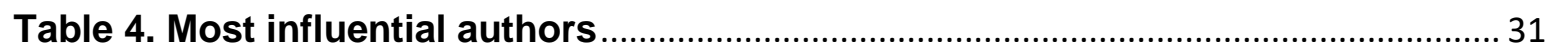

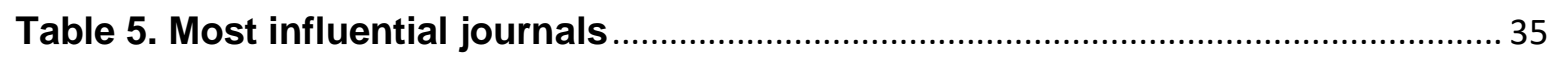

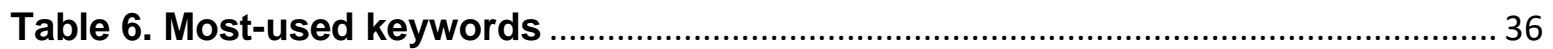

Table 7. Summary of articles in the tree of science of the internationalisation of

SMEs and the theory of effectuation........................................................................... 42

Table 8. Contrarian cases and main features of firm samples in this study .............. 62

Table 9. The causal configurations for achieving accelerated internationalisation of

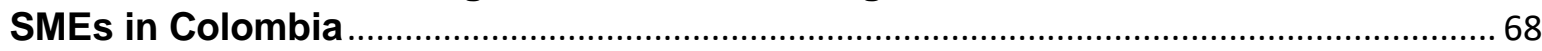

Table 10. The causal configurations for achieving accelerated internationalisation of

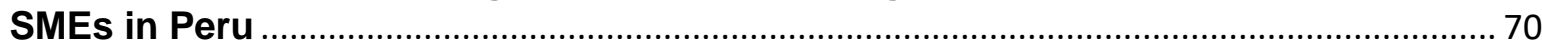

Table 11. Descriptive statistics and Correlation Matrix .............................................. 92

Table 12. Estimates of ordinal logistic regression model .......................................... 94

\section{List of Figures}

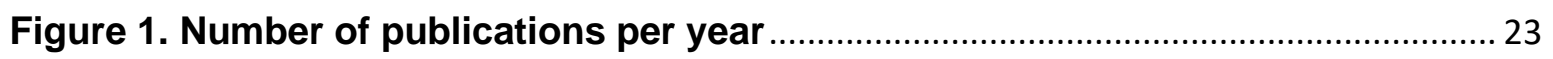

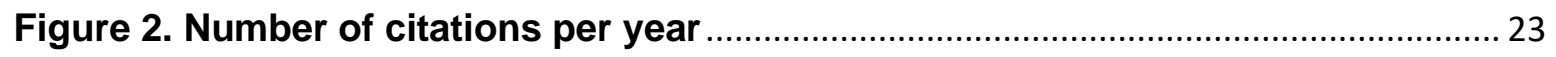

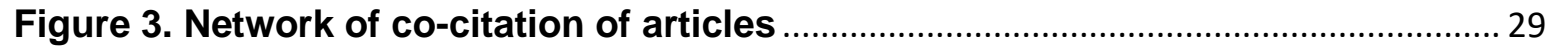

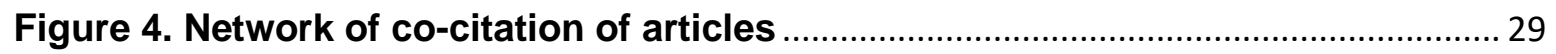

Figure 5. Network of co-authors: related nodes ...................................................... 33

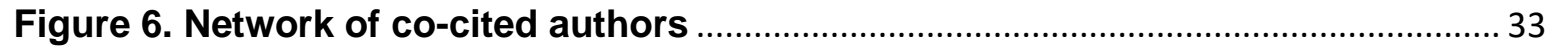

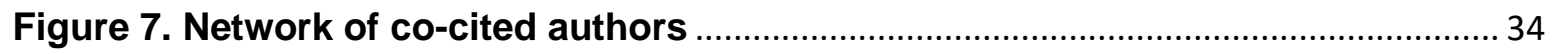

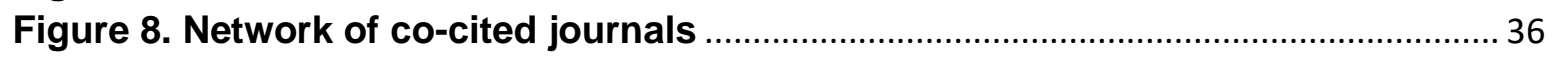

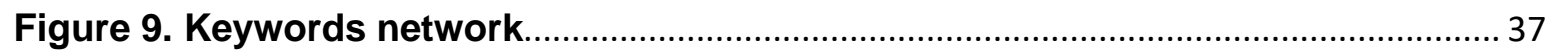

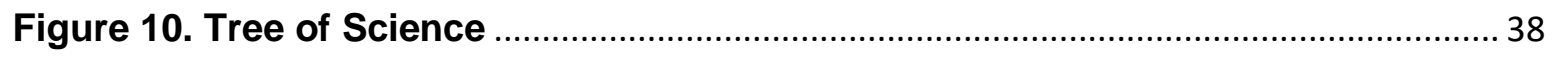

Figure 11. Integrative model for accelerated internationalisation .............................. 72

Figure 12. Conceptual model of accelerated internationalization................................. 97 


\section{Publications}

This thesis was develop as a compendium of articles that were published in international journals indexed in Scimago (Scopus) and JCR. Those articles are:

- Bibliometric analysis of the theory of effectuation and the internationalisation of small and medium-sized enterprises. European Journal of International Management, in-press. https://doi.org/10.1504/EJIM.2020.10026119

- When do domestic networks cause accelerated internationalisation under different decision-making logic? Evidence from weak institutional environment. European Business Review, 32(4), in-press. https://doi.org/10.1108/EBR-11-2018-0191

Additionally, the following conference papers were developed:

- "The Influence of Weak Institutional Environment, Effectuation and Domestic Networks on Accelerated Internationalisation: A Study of Latin American SMEs", Regional Studies Association Latin America Division Conference (2019). Bogota, Colombia.

- "Análisis Bibliométrico del Modelo de Efectuación y la Internacionalización de las Empresas", Congreso Iberoamericano de Economía Aplicada ASEPELT (2018). Cartagena, Colombia.

- "Análisis Bibliométrico de la Internacionalización Acelerada", III Congreso Internacional de Investigación en Competitividad, Sostenibilidad y Relaciones Internacionales de la Red Radar (2018). Bogota, Colombia. 
- "When domestic networks cause accelerated internalization under different levels of effectuation? Evidence from Colombian SME's" XVI Doctoral Colloquium of CLADEA (2018). San Jose, Costa Rica.

- "Redes, el primer paso para que las microempresas aprovechen los Acuerdos de Libre Comercio", en el XIII Foro Internacional del Emprendedor: Comercio exterior para el emprendimiento y las MIPYME (2017). Quito, Ecuador. 


\section{Chapter One - Introduction and objectives}

\subsection{Research Background}

The accelerated internationalisation process of Small and Medium Enterprises (SMEs) is a phenomenon that has dominated international business research for the past three decades (Baier-Fuentes, et al., 2019). Despite limited financial, human, and intangible resources, these firms are able to internationalize from a very early stage (Cavusgil \& Knight, 2009). Several authors have identified the article of Oviatt and McDougal (1994) as the groundwork that support the development of the new research field called "Born Global firms" (Autio, 2005). In this article, Oviatt and McDougal (1994) explore SMEs that are international from inception, challenging the conventional theories of incremental such as the Uppsala model.

Traditionally, the internationalisation process of the firm was explain as a gradual process which is based on the networks of company and the acquisition of knowledge (Johanson \& Vahlne, 2009). According to this model, firms would gradually expand to nearby markets, which have closer geographic distance originating from liability of foreignness. Then, after acquiring more knowledge, experience and strengthen the firm's position in the foreign networks, companies would decide to enter more distant markets (Johanson \& Vahlne, 2009). In contrast, the born global firm model explains that the internationalisation of SMEs does not follow this gradual process, and shows that thanks to the networks and the exchange of knowledge, SMEs can be internationalized during their first years of life (Coviello \& Cox, 2006). In this model, the defining characteristic of a born global firm is its accelerated internationalisation process (Weerawardena, et al., 2007).

Accelerated internationalisation, has been defined in terms of the length of time between inception and first international sales (speed); the number of foreign countries in which sales are generated (scope), and the percentage of foreign on total sales (extent) (Kuivalainen, et al., 2007; Madsen, 2013; Weerawardena et al., 
2007; Zahra \& George, 2002). Among the factors that might explain accelerated internationalisation, network strength (strong or weak ties) and decision-making logic (effectuation or causation) seem to be the most promising (Andersson, 2011; Galkina \& Chetty, 2015; Kujala \& Törnroos, 2018; Sarasvathy et al., 2014; Schweizer, et al., 2010). Similarly, research on the impact institutional voids (also known as weak institutional environment) has proved to be a crucial factor (CuervoCazurra, et al., 2018).

In relation to network strength, it can be classified into strong or weak ties depending on the amount of time, emotional intensity, intimacy, and reciprocal communication among firms (Granovetter, 1973). Strong ties are define as one that has active participation and commitment, with often contact and trust. In contrast, weak ties passive participation and commitment, with not very often in contact (Söderqvist \& Chetty, 2013). Strong ties can constrain access to new information and opportunities; while weak ties can serve as bridges to diverse resources and novel information (Hayton, Chandler, \& DeTienne, 2011; Johanson \& Vahlne, 2006; Uzzi, 1997). Networks can also be classified into foreign or domestic networks (also known as non-local or local networks; Prashantham \& Birkinshaw, 2015). Research on networks and accelerated internationalisation has mostly focused on foreign networks (Prashantham \& Birkinshaw, 2015). To a great extent, findings suggest that foreign networks provide internationalisation knowledge and help to identify business opportunities (Chetty \& Blankenburg Holm, 2000; Fernhaber \& Li, 2013; Knight \& Cavusgil, 2004; Schwens \& Kabst, 2011). However, a more recent stream of research argue that domestic networks can also enhance accelerated internationalisation (Manolova, et al., 2010; Ryan, et al., 2019). It seems that domestic networks increase the propensity to export (Boehe, 2013) and give access to foreign networks (Montoro-Sanchez, Diez-Vial, \& Belso-Martínez, 2018).

Regarding the decision-making logic Internationalisation can happen as a result of causation (planned and predictive) or effectuation (unplanned and non-predictive; Kalinic, Sarasvathy, \& Forza, 2014). The traditional body of internationalisation research is based on rational decision making models, called causation (Sarasvathy, 
et al., 2014). Causation is a goal-driven approach in which future is predictable; therefore, it usually involves actions such as analysing long-run opportunities and selecting the ones that might deliver the best returns; designing a strategy to take advantage of resources and capabilities; developing business plans; doing market research; analysing the competitor's environment; and implementing and controlling the process to achieve these goals (Chandler et al., 2011). Research have demonstrate that causation logic can enhance internationalisation (Brewer, 2001; Brouthers \& Nakos, 2005; Lukas, Whitwell, \& Hill, 2007). It seems that causation help firms to manage their scarce resources effectively and efficiently (Cao, et al., 2009). Likewise, by predicting the future and setting goals and plans, firms are able to earn potential investments (Nummela, et al., 2014).

In yet contrast, effectuation is a means-driven approach in which future is unpredictable (Sarasvathy, 2001). Effectuation logic is a decision-making process consisting on mobilizing resources and capacities within the control of their network to co-create the future (Sarasvathy et al., 2014). It also focuses on opportunity development and on taking advantage of unexpected outcomes (Chetty, Ojala, \& Leppäaho, 2015; Sarasvathy \& Dew, 2005). The effectual approach is based on the following principles: 1) available means, including who I am, what I know, and whom I know; 2) experimentation, which means trying different approaches before starting the venture; 3) affordable loss, which refers to estimating how much loss is affordable rather than calculating expected returns; 4) flexibility to explore new opportunities; and 5) pre-commitments within the network to control the future (Sarasvathy, 2008). Recent studies have found that under conditions of uncertainty, effectual decision-making logic is more efficient to achieve accelerate internationalisation than causation logic (Laine \& Galkina, 2017). By implementing effectuation logic, firms can use their existing resources to experiment and identify international opportunities (Sarasvathy, 2001).

Finally, institutional voids has proved to be a crucial factor in explaining the internationalisation process of the firm (Khanna, et al., 2005; Santangelo \& Meyer, 2011; Verreynne, et al., 2016). Institutional voids is define as a context that is 
characterized by absence or underdevelopment of regulatory institutions and enforced structure of laws (Scott, 2014), which usually generates political instability and corruption (Hiatt \& Sine, 2014). This environment is likely to be problematic for the internationalisation of the firms, because it creates adds operation costs at home and reduces firm performance (North, 1990; Spencer \& Gomez, 2011; Tang, Tang, \& Katz, 2014). However, this environment can also push firms to develop special advantages, explore international opportunities to diversify risk and consequently reach accelerated internationalisation (Cuervo-Cazurra, et al,, 2018; Jones, 2012; Luo, et al., 2010).

\subsection{Research problem and objectives of the thesis}

A review of the literature suggests that there have been discrepancies among researchers about the individual effect of domestic networks strength, decisionmaking logic and institutional voids on accelerated internationalisation. Moreover, scholars argue that accelerated internationalization is a complex phenomenon that should be studied by identifying the complex relations among variables (Chetty, Johanson, \& Martín, 2014). However, to our knowledge, no studies have explore the interaction effect and the connection of these factors. Therefore, there have been calls to increase the understanding of the effects of these variables on the accelerated internationalisation of SMEs (Casillas \& Acedo, 2013; Coviello, 2015; Madsen, 2013). Moreover, limited research has been conducted that moves beyond foreign networks to alternatively explore the role of domestic networks (Milanov \& Fernhaber, 2014; Montoro-Sanchez et al., 2018; Prashantham \& Birkinshaw, 2015; Xu, Lin, \& Lin, 2008).

Recent literature suggest that one promising avenue for future research is to incorporate effectuation decision-making logic to explore the internationalisation process of SMEs (Read, et al., 2016; Reuber, et al., 2016). Nevertheless, effectuation is an emerging scientific field that lacks conceptual clarity (Arend, Sarooghi, \& Burkemper, 2015; Fischer \& Reuber, 2011; Goel \& Karri, 2006). 
Additionally, there is a need for studies that clarify these discrepancies by advancing the scarce research of accelerated internationalisation in context characterized by institutional voids (Boehe, 2013; Haddoud, Jones, \& Newbery, 2017; Knight \& Liesch, 2016). In relation to this matter, researchers recommend to further investigate Latin American countries because this region is characterized by having institutional voids, but has been a neglected research context (Cardoza, et al., 2016; Ciravegna, et al., 2016; Lingelbach, et al., 2015; Pawęta, 2016; Torkkeli \& Fuerst, 2018).

The discrepancies among researchers is evident. For instance, some studies find that strong network ties facilitate knowledge sharing and resource exchanging and therefore, accelerate internationalisation (Gulati, Lavie, \& Madhavan, 2011; Söderqvist \& Chetty, 2013). Close interactions among partners foster the emergence of common norms and trust that reduce risk and opportunism; however, repeated interaction with close partners progressively leads to redundancy, and reduces information novelty (Hayton, et al., 2011). While some others show that weak network ties accelerate internationalisation (Galkina \& Chetty, 2015). Firms use their weak ties to share novel information, help to identify different opportunities, and therefore, reduce uncertainty and accelerate internationalisation (Kontinen \& Ojala, 2011; Rindfleisch \& Moorman, 2001). Particularly, access to non-redundant information opens avenues for alternative strategies and decision-making that spur internationalisation (Granovetter, 1973).

Similarly, there is not a consensus about the impact of the decision-making logic on the accelerated internationalisation (Jones, Coviello, \& Tang, 2011; Schweizer, Vahlne, \& Johanson, 2010; Spence \& Crick, 2006). Some scholars argue that causation logic enhances internationalisation (Brewer, 2001; Brouthers \& Nakos, 2005; Lukas et al., 2007). By implementing this decision-making logic, firms are able to manage their scarce resources effectively and efficiently (Cao et al., 2009), earn potential investments (Nummela et al., 2014), and reduce the risk of going international (Sarasvathy, 2001). Nevertheless, recent studies, argues that effectuation decision-making logic speeds internationalisation for the following 
reasons: First, effectuation logic allow firm to identify international opportunities (Andersson, 2011). Second, successful international firms prefer to use the logic of effectuation to decide on their entry mode (Harms \& Schiele, 2012). Moreover, firms use effectuation logic to create their international networks (Galkina \& Chetty, 2015). Finally, the logic of effectuation help firms to overcome their resource constraint (Kujala \& Törnroos, 2018).

An explanation for the mixed results might lie in the characteristic of the context. It seems that under conditions of uncertainty, effectual decision-making logic is a more efficient logic than causation (Laine \& Galkina, 2017). The pre-commitments involved in the effectual thinking, define what firms will do with their partners. Hence, firms are able to control the future and cope with uncertainty (Wiltbank \& Sarasvathy, 2010). Moreover, firms uses their existing resources to experiment and identify international opportunities (Sarasvathy, 2001). In this way, firms may achieve the possible best outcomes with the resources at their disposal, and thus accelerated their internationalisation process.

Taking into account the explanatory potential of effectuation, the Uppsala internationalisation model and the internationalisation model of born global firms have integrate this decision-making logic in their frameworks. Schweizer et al. (2010) adapted the Uppsala internationalisation model (Johanson \& Vahlne, 2009) by integrating the entrepreneurial process and principles of the theory of effectuation. Similarly, Andersson (2011) and Harms and Schiele (2012) integrated the theory of effectuation into the born global internationalisation model to explain the process of identifying international opportunities (Andersson, 2011) and the choice of entry mode (Harms and Schiele, 2012). Hence, by integrating the effectuation theory into these models, scholars focused on explaining the internationalisation of SMEs using the entrepreneur, the decision-making process and the impact on the company as the units of analysis (Matalamäki, 2017).

Regarding the impact of the institutional voids on the accelerated internationalisation of the firm, different results have been reached. On the one hand, some studies 
argue that institutional voids may encourage firms to explore international opportunities to diversify risk (Aulakh \& Kotabe, 2008; Cuervo-Cazurra, Ciravegna, Melgarejo, \& Lopez, 2018; Jones, 2012). To explain this effect, scholars have proposed the institutional escapism view (Witt \& Lewin, 2007; Yamakawa, Peng, \& Deeds, 2008). This view suggests that firms based in a context of institutional void, internationalize more aggressively than firms located in a context of strong institutions (Luo et al., 2010). For some firms, institutional voids have become a training ground to develop advantages through their exposure to uncertainty, which lead them to achieved accelerated internationalisation (Cuervo-Cazurra, et al., 2018). Moreover, uncertainty can push firms to develop resources and capabilities needed for fast foreign market expansion (Witt \& Lewin, 2007). Finally, institutional voids may also motivate firms to create informal domestic networks that help them to internationalize (Narooz \& Child, 2017).

On the other hand, literature suggests that institutional voids negatively affects the accelerated internationalisation of the firms (Cardoza, et al., 2016; He \& Cui, 2012; Johanson \& Vahlne, 2009). This environment is likely to be problematic for the internationalisation of the firms, because it reduce the competitiveness of the firms, and hence, their internationalisation process (Hitt, et al., 2005). The reason is that firms are constrained by unsophisticated market, difficulty in accessing strategic resources and therefore, present little specialization (Cuervo-Cazurra, 2012; Sharma, 2011). Moreover, the unnecessary legal, political and economic challenges that institutional voids adds costs and reduces international firm performance (Tang, Tang, \& Katz, 2014; Torkkeli \& Fuerst, 2018). It has been suggested that even, if the firm is benefit by government internationalisation support, institutional voids lessen its internationalisation process (Kaur \& Sandhu, 2014).

Given the mixed and contradictory arguments exposed above, the main focus of this research is to clarify the discrepancies among researchers about the effect of networks strength, decision-making logic and institutional voids on accelerated internationalisation of SMEs. Moreover, given the identified research gaps, this research aims to explore the micro-mechanisms that connect these factors and the 
mediating effects and multiple interactions among them. This research also aims to identify the conceptual structure of effectuation.

Thus, the research objectives include the following:

- To identify the conceptual structure and key trends of effectuation and internationalisation of SMEs (Chapter 2).

- To explore the causal conditions (type of network strength and type of decision-making logic) for achieving accelerated internationalisation in SMEs located in context of institutional voids (Chapter 3 ).

- To investigate micro-mechanisms that connect the impact institutional voids, effectuation and domestic networks strength on the accelerated internationalisation of SMEs (Chapter 4).

\subsection{Overview of the research}

In order to achieve the first objective of this doctoral dissertation, a bibliometric analysis of 30 articles collected from the Web of Science database was performed. To test the robustness of the results, a bibliometric analysis of 25 articles collected from Scopus database was accomplished. Through this methodology, it is possible to evaluated the development of the literature by identifying its co-occurrence relationship, the structure of scientific networks and the intellectual structure (Leeuwen, 2006). Moreover, to identify the authors, scientific journals, institutions and countries that contribute to the development of the research area (Yu \& Shi, 2015). Likewise, this research methodology is suitable to generate maps that represent the connections within the research field (Cobo, et al., 2015). Finally, using the results of this analysis and implementing the Tree of Science software, it is possible to identified the structure of the research field (Robledo Giraldo, et al., 2014). This structure has a root, where the articles that form the basis of the field are found, a trunk, where the articles that lend structure to the research field are found, 
and branches, which correspond to the most recent articles. Accordingly, the articles in the root and trunk provide a clearer vision of the foundations and evolution of the field, whereas the articles in the leaves indicate where the field of research is evolving to.

The articles that provide the basis of the field indicate that the conceptual and theoretical basis consists of the theory of effectuation (Sarasvathy, 2001), born globals and analysis of born globals using the theory of effectuation (Andersson, 2011; Harms \& Schiele, 2012; Oviatt \& McDougal, 1994), the Uppsala model and analysis of this model using the theory of effectuation (Johanson \& Vahlne, 1977, 2009; Schweizer et al., 2010), international entrepreneurship (Jones et al., 2011), and theory creation based on case studies (Eisenhardt, 1989; Yin, 2003).

Research on the effectuation and internationalisation of SMEs is structured into five areas: 1) The decision-making process of entrepreneurs during the internationalisation of the company; 2) The development of international entrepreneurship based on the theory of effectuation; 3) The analysis of entrepreneurial marketing using the theory of effectuation; 4) The impact of effectuation logic on knowledge acquisition, international opportunity identification and network creation; and 5) The impact of effectuation logic on the growth and survival of SMEs in international markets. The most recent articles show that the trend of research on the internationalisation of SMEs and the theory of effectuation is oriented towards furthering the knowledge of the five areas that lend structure to this field of research.

To achieve the second objective, a fuzzy-set qualitative comparative analysis (fsQCA) to examine the accelerated internationalisation of 33 contrarian cases of SMEs located in Colombia and Peru was performed. The data set was collected through in-depth interviews with managers in Colombia (21 cases) and Peru (12 cases). These countries are characterized for having institutional voids (Levitsky \& Murillo, 2013; Mesquita \& Lazzarini, 2008). Unlike traditional statistic methods, that treat configurations as separate types of cases and assume that the relationships 
between the dependent and independent variables are symmetric, fsQCA accept asymmetric relationships between the dependent and the independent variable (Bell, Filatotchev, \& Aguilera, 2014; Rihoux \& Ragin, 2009; Woodside, 2013). It means that fsQCA help to identify several equifinal combinations of dependent variables that are sufficient to produce the independent variable (Woodside, 2013).

A model with two testable propositions is developed which prepares the ground for future empirical research. The propositions are: 1) strong domestic ties combined with causation logic accelerate the internationalisation of firms with greater resource constraints that are located in contexts with institutional voids, and 2) weak domestic ties combined with effectuation logic accelerate the internationalisation of firms with fewer resource constraints that are located in contexts with institutional voids.

Finally, to meet the third objective, we performed an ordinal logistic regression model to establish associations between location, institutional voids, effectual networking and network strength on the accelerated internationalisation of Latin American SMEs. For this purpose, firm-level data for Argentina, Colombia and Peru from the World Bank's Enterprise Surveys (ES) database was used. The World Bank collects the data systematically, using standardized surveys and stratified sampling techniques to ensure representative coverage for a given country. This allows comparison among countries. The ES has been used and validated by academics from international entrepreneurship research of emerging economies (e.g., Deng \& Zhang, 2018; Krammer, et al., 2018; Wu, 2016). Based on this data, an ordinal variable was constructed, representing the level of accelerated internationalisation of the firm. This variable equals 0 if the company is not internationalize. It equals 1 if the firm is internationalized but does not meet any of the above mentioned characteristics for accelerated internationalization. It equals 2 , if the firm meets one characteristic. It equals 3 , if the firm meets two characteristics. Finally, it equals 4 , if the firm meets the three characteristics of accelerated internationalization. The data includes 991 SMEs from Argentina, 993 SMEs from Colombia and 1,003 SMEs from Peru. 
A set of hypotheses was tested including interaction effect. The results reveals that rural cities, as opposed to first- and second-tier cities, have characterized firms' accelerated internationalization processes. In addition, institutional voids have a positive influence on the acceleration of the internationalization process. Moreover, firms that use effectual networks have a higher likelihood of accelerated internationalization. Furthermore, firms that have strong domestic ties have a higher likelihood of accelerated internationalization. Regarding the interaction effects, firms located in a context of significant institutional voids which also have effectual networking, have a higher likelihood of accelerated internationalization. Similarly, the size of the firm moderated the impact of strong local ties on the likelihood of accelerated internationalization. Results also shows that firms that have strong local ties and are located in rural cities have a higher likelihood of accelerated internationalization.

Finally, size, foreign ownership, having internationally recognized quality certification, not been affected by trade regulations and informal competition, access to government contracts and sector increase the odds of reaching accelerated internationalization.

\subsection{Structure of the doctoral thesis}

This thesis integrates the notions of accelerated internationalisation, effectuation theory, domestic networks strength and institutional voids. Overall, this thesis consists of six chapters, plus references, which includes: The first chapter introduce the research background, the research problem and objectives of the thesis, the overview of the research and the structure of the doctoral thesis.

The second chapter presents a review of the literature on the theory of effectuation and the internationalisation of small and medium-sized enterprises. Bibliometric analysis of 30 articles collected from the Web of Science database was performed. Using Bibexcel, VOSviewer, Pajek and Tree of Science to analyse the data, mathematical and statistical methods were applied to classify the literature and 
identify its structure and key trends. The results of the bibliometric analysis are based on evaluation of the most influential authors, articles and journals. The impact of the articles was evaluated, and the structure of the research field was identified. To test the robustness of the results, we also run a bibliometric analysis of 25 articles collected from Scopus database. This analysis revealed substantial similarities that allow us to identify the conceptual structure of this research field. This chapter was accepted to be published on the European Journal of International Management, for the ongoing special section called "The State of the Art in International Management". This journal is indexed in Scopus (Scimago - Q2) and Web of Science (JCR - Q4).

The purpose of the third chapter is to combine theoretically relevant antecedents of domestic networks relationships (weak or strong domestic ties) and decision-making logic (effectuation or causation) to explore the configurations that are the most promising for explaining accelerated internationalisation. This chapter uses fuzzyset qualitative comparative analysis (fsQCA) to examine the accelerated internationalisation of 33 contrarian cases of micro and small-enterprises located in contexts with institutional voids. The data set has been collected through in-depth interviews with managers in Colombia (21 cases) and Peru (12 cases). We found that the combination of weak domestic ties and effectuation logic accelerated the internationalisation of SMEs with fewer resource constraints. In contrast, strong domestic ties and causation behaviour lead to accelerated internationalisation of SMEs with greater resource constraints. We propose a model to help enrich the existing literature about the causal configurations for achieving accelerated internationalisation in SMEs from countries characterized by institutional voids. The contribution of this chapter is to provide empirical evidence to address three shortcomings in the literature. First, the mixed results regarding the impact of strong and weak domestic ties and decision-making logic in the accelerated internationalisation of SMEs; second, the limited research on domestic networks; and third, the scarce investigation in contexts with institutional voids, where the emphasis on constrained resources is higher. This chapter was accepted to be 
published on the European Business Review. This journal is indexed in Scopus (Scimago - Q2).

The fourth chapter examines the micro-mechanisms that connect the impact of location, institutional voids, effectual networking and networks strength on the accelerated internationalisation of Latin American SMEs. By analysing a dataset of 2.987 Small and Medium Enterprises (SMEs) from Argentina, Colombia and Peru, results show that (1) rural cities, instead of first- and second-tier cities, accelerated the internationalisation process of the firm. (2) Institutional voids, effectual networks and strong domestic ties increase the likelihood of accelerated internationalisation. Finally, (3) we found a robust and high interaction effect between strong domestic ties with high institutional voids, rural location and effectual networking on accelerated internationalisation.

The fifth chapter present a general discussion of the results. The final chapter (chapter 6) presents the conclusions. This section discusses implications of this research for business practitioners, and national policy makers, as well as the limitations of research, and the recommendations of future research. References and appendices are presented at the end of this thesis. 


\section{Chapter Two - Bibliometric analysis of the theory of effectuation and the internationalisation of small and medium-sized enterprises}

\subsection{Introduction}

Since the publication of Sarasvathy's (2001) seminal article, there has been growing interest in using the theory of effectuation to understand the internationalisation of small and medium-sized enterprises (SMEs; Chandler et al., 2011; Galkina and Chetty, 2015; Perry et al., 2011). The theory of effectuation provides a model to understand how entrepreneurs create businesses in contexts characterised by high uncertainty and unpredictability about the future (Sarasvathy, 2001). More specifically, this theory focuses on understanding the decision-making processes of these entrepreneurs. Sarasvathy (2001) showed that entrepreneurs follow an unplanned path, called effectuation, which is defined by their identity ('who I am'), their networks ('who I know') and their knowledge ('what I know'). The models that explain the internationalisation of SMEs are also largely based on networks ('who I know') and knowledge ('what I know'; Chetty and Blankenburg Holm, 2000). For example, the Uppsala internationalisation model explains internationalisation as a gradual process that stems from the networks of the company and the acquisition of knowledge (Johanson and Vahlne, 2009). In contrast, the born global model proposes that the internationalisation of SMEs does not follow a gradual process. Instead, thanks to networks and the exchange of knowledge, SMEs can internationalise in their first few years (Cavusgil and Knight, 2009).

In addition to these similarities, the theory of effectuation, the Uppsala model and the born global model are all contextualised in settings of high uncertainty and unpredictability about the future. Consequently, effectuation principles are relevant to analysing firms' internationalisation processes (Harms and Schiele, 2012). However, despite these common elements, this research field developed slowly between 2001 and 2011 and faced criticism over the lack of empirical research supporting its development (Arend et al., 2015; Reuber et al., 2016). This period is 
known as the stage of nascent development of effectuation theory (Perry et al., 2011). This trend changed in 2011 , when the number of studies seeking to explain the internationalisation of SMEs through the theory of effectuation started to increase (Chetty et al., 2015; Kalinic et al., 2014; Sarasvathy et al., 2014). The internationalisation of companies has been identified as one of the areas where the theory of effectuation has had the greatest impact (Matalamäki, 2017).

Despite these advances, several authors have suggested that this research field lacks conceptual clarity and intellectual structure and that the path for its future development is unclear (Arend et al., 2015; Fischer and Reuber, 2011; Goel and Karri, 2006). Moreover, to the best of the authors' knowledge, no study has presented bibliometric analysis of the theory of effectuation and the internationalisation of SMEs. Given this gap in the literature, this article aims at identifying the structure and development of this research field over time by classifying the literature and determining its structure and key trends (Adriaanse and Rensleigh, 2013). Scholars should find our bibliometric study helpful as a quantitative starting point for literature reviews in further studies. Likewise, our study also provides a general introduction of the intellectual structure of the theory of effectuation and the internationalisation of SMEs.

Bibliometric analysis is one of the most widely used methodologies to achieve research goals such as ours (Chabowski et al., 2017). This methodology is based on two approaches (Cobo et al., 2015). The first approach is to use a series of indicators to evaluate the impact of the articles in a given field of study. The second approach is to identify the structure and dynamic aspects of the research field. This approach entails performing bibliographic coupling and co-citation analysis. Bibliographic coupling consists of studying the citing documents, whereas co-citation analysis consists of exploring the cited documents (Van Eck and Waltman, 2014). In this article, we present bibliometric analysis of the theory of effectuation in relation to the internationalisation of SMEs. We used the Web of Science database (WoS) and articles on the theory of effectuation and the internationalisation of SMEs published between 2001 and 2018. To test the robustness of the results, we reply 
the bibliometric analysis with the Scopus database. The results revealed substantial similarities that allow us to identify the conceptual structure of this research field. Following the method described in similar articles, the data were analysed using Bibexcel, VOSviewer, Pajek and Tree of Science software (Baier-Fuentes et al., 2018; Dzikowski, 2018).

This article is organised as follows. First, we describe the state of the art of the theory of effectuation and the internationalisation of SMEs. Second, the method is described, and a brief description of bibliometric methods is given. Third, the results of the bibliometric analysis are presented, and the conceptual structure of the literature is explained. Finally, conclusions, limitations and research opportunities are presented.

\subsection{Literature review}

\subsubsection{Theory of effectuation and the internationalisation of SMEs}

The theory of effectuation was developed to understand the decision-making processes of entrepreneurs in scenarios with high uncertainty and unpredictability about the future (Sarasvathy, 2001). This model proposes that entrepreneurship tends to develop from a non-predictive logic instead of a rational, predictive logic (Sarasvathy, 2008). The rational, predictive logic is called causation and is characterised by entrepreneurs asking what goals they want to obtain (clear objectives) and then focusing on selecting resources to achieve these goals. In contrast, the non-predictive logic is called effectuation and consists of entrepreneurs asking what they can achieve with the resources they have and, from these resources, setting or discovering their goals (Sarasvathy, 2001). The logic of causation suggests that entrepreneurs can predict the future and control it to achieve a set objective, whereas, under the logic of effectuation, entrepreneurs do not intend to predict the future but instead use their resources to turn the future into a source of opportunities (Sarasvathy, 2008). The theory of effectuation is defined by five principles. The actions of entrepreneurs are characterised: first, by the resources they have rather than by a predetermined objective; second, by taking advantage of 
the opportunities that arise instead of exploiting prior knowledge; third, by how much they are willing to risk and not how much they want to earn; fourth, by seeing the environment as an opportunity to create alliances instead of a competition; and, fifth, by seeking to control the future rather than predict it (Chandler et al., 2011).

Given the relevance of the theory of effectuation in entrepreneurship studies, two literature reviews have documented the development of this field (Matalamäki, 2017; Perry et al., 2011). In the first review, Perry et al. (2011) used article classification systems to identify the relevance of effectuation to explain entrepreneurs' behavior. It highlights the need to create instruments to measure its and suggests that this research field is in a nascent stage. Matalamäki (2017) complemented this review. Based on bibliometric analysis, the review shows that the research field has advanced from a nascent stage to an intermediate stage and that effectuation is influencing research on innovation and the development of new products, the coexistence of causation and effectuation, the entrepreneur's expertise, and the internationalisation of companies. The author also underscored the need for further study of the impact of effectuation on these four areas'.

Given the similarities between the entrepreneurial process and the internationalisation process, studies on international entrepreneurship have found the theory of effectuation particularly useful to explain the internationalisation of SMEs (Jones et al., 2011). This process is influenced by the uncertainty of international markets, the limited resources of these companies and the dynamics of corporate networks. Accordingly, this process can be summarised by answering the following questions: Who am I? What do I know? Who do I know? (Andersson, 2011; Harms and Schiele, 2012; Sarasvathy et al., 2014).

From the perspective of the internationalisation of SMEs, both the Uppsala internationalisation model and the internationalisation model of born global firms have been enhanced by integrating the theory of effectuation. Originally, the Uppsala model predicted that companies would internationalise gradually. Accordingly, as the company gradually increased its international expansion, it would gain international 
knowledge and experience (Johanson and Vahlne, 1977). According to this model, companies would begin their international expansion to nearby markets through simple entry modes that required little international knowledge and experience such as indirect exports. Then, after acquiring more knowledge and experience, companies would decide to enter more distant markets through more complex entry modes such as foreign direct investment (Johanson and Wiedersheim-Paul, 1975). This model was criticised for its deterministic approach (Reid, 1983), its unfamiliarity with company strategy (McDougall et al., 1994), and its emphasis on the acquisition of knowledge and resources (Andersen, 1993). Therefore, the model was adjusted and redefined to integrate the concept of networks (Forsgren et al., 2015). This new model explains the internationalisation of companies based on their position within the network and the disadvantages of lying outside this network (Johanson and Vahlne, 2009). Likewise, it establishes that the theory of effectuation is consistent with the model (Johanson and Vahlne, 2009, p. 1423). Therefore, the theory of effectuation was explicitly included in the Uppsala model (Schweizer et al., 2010).

Criticisms of the Uppsala model led to an alternative view that sought to explain the internationalisation of companies that did not follow a gradual process but that internationalised instinctively over a short period following their creation (Oviatt and McDougal, 1994). This model is the born global model, and it explains internationalisation based on the importance of corporate networks to overcome their lack of experience and resources (Knight and Cavusgil, 2004). This model has been developed and complemented by integrating various theoretical contributions. These include the resource-based view, which focuses on the assets, capabilities and knowledge of the company (Rialp and Rialp, 2007; Wernerfelt, 1984), the capabilities view, which considers the capabilities of the company as an advantage that can be exploited (Teece et al., 1997; Weerawardena et al., 2007), the knowledge-based view, which considers knowledge the most important resource (Autio et al., 2000; Grant, 1996), network theory, which depicts networks as a source of assets, capabilities and knowledge (Coviello, 2006; Ellis, 2011), and the international enterprise, which explains internationalisation through the analysis of entrepreneurial behavior (McDougall, 1989; Peiris et al., 2012). 
In a study of international entrepreneurship, Andersson used the theory of effectuation to explain the internationalisation of born global firms. Andersson (2011) argued that international opportunities are identified under the logic of effectuation. Similarly, Harms and Schiele (2012) used the theory of effectuation to explain the process of choosing the entry mode to enter international markets. They found that more experienced entrepreneurs prefer to use the logic of effectuation to decide on their entry mode. More recently, Galkina and Chetty (2015) used the theory of effectuation to understand how companies create their networks. The authors concluded that this process follows the logic of effectuation. Finally, Kujala and Törnroos (2018) found that the capabilities of companies and the logic of effectuation explain the internationalisation of companies in Ghana.

Given the increasing importance of the theory of effectuation in explaining the internationalisation of companies, bibliometric analysis of the internationalisation of SMEs and the theory of effectuation is important for three reasons. First, there is a need for more in-depth analysis of the effectuation and internationalisation of SMEs (Jones et al., 2011; Matalamäki, 2017). Second, despite conceptual advances regarding the linkages between the theory of effectuation and the models that explain the internationalisation of SMEs, authors have suggested that this field of research is incomplete and that it lacks conceptual clarity and empirical evidence (Arend et al., 2015; Fischer and Reuber, 2011; Goel and Karri, 2006; Jones et al., 2011). Third, there is an absence of studies that not only focus on descriptive methods but also use mathematical and statistical methods to perform citation analysis, identify co-citation networks and establish the conceptual structure of this field (Cobo et al., 2015)

\subsection{Method}

The literature was analysed using a qualitative approach based on bibliometric analysis. We thus evaluated the development of the literature and its influence on knowledge development (Leeuwen, 2006). Additionally, by using keywords in the bibliometric analysis, we analysed a field of research and its relationships in detail 
at the micro level (Chen and Xiao, 2016). This analysis was performed using two approaches. The first was to evaluate the impact of the citations of the actors in this area. These actors are the authors, scientific journals, institutions and countries that contribute to the development of the research area. This approach is based on the use of different indicators, the most common of which are number of citations, number of publications and the $\mathrm{H}$ index (Yu and Shi, 2015).

The second approach was to generate maps that represent the connections within the research field (Cobo et al., 2015). This approach requires specialised software. The most widely used programs are Bibexcel (Persson et al., 2009), VOSviewer (Van Eck and Waltman, 2010) and Pajek (Mrvar and Batagelj, 2016). These programs enable analysis of co-citations, bibliographic coupling and co-word analysis (Peters and Raan, 1991). Using these analyses and Tree of Science software, we identified the structure of the research field (Robledo Giraldo et al., 2014). This structure has a root, where the articles that form the basis of the field are found, a trunk, where the articles that lend structure to the research field are found, and branches, which correspond to the most recent articles. Accordingly, the articles in the root and trunk provide a clearer vision of the foundations and evolution of the field, whereas the articles in the leaves indicate where the field of research is evolving to.

The publications analysed in this article were gathered from WoS. WoS can be used to select the academic articles that are of greatest importance in a given research field (Zupic and Čater, 2015). The keywords used for the search were effectuation and international. These words were searched for in the titles, abstracts and keywords of articles. The search was conducted in English and was restricted to the period from 2001 to 2018 . The conceptual basis for the theory of effectuation was formulated in Sarasvathy's (2001) seminal article, so the year 2001 was taken as the starting year for the search. Following Leeuwen's (2006) method, we studied the titles, abstracts, and keywords of the articles returned by the search to select only those that were directly related to the subject of this study. Following this procedure, 30 articles were selected. To evaluate the validity and reliability of our findings, the 
following actions were taken: First, we replicated the methodology described above using Scopus database. Scopus was selected because is the second more frequently used databased for bibliometric analysis (Zupic \& Čater, 2015) and it is a complementary database for WoS (Durán-Sánchez, et al., 2017). Therefore, the articles included on Scopus database should be able to confirm the conceptual structure of the research field (Zupic \& Čater, 2015). Second, after reviewing the titles, abstracts, and keywords, we selected 25 articles. Next, we identified the cooccurrence relationship, the structure of scientific networks and the intellectual structure. Finally, we compare the results of both databases to suggest the conceptual structure of this research field.

\subsection{Results of the bibliographic analysis}

\subsubsection{General results}

This section presents the results of the bibliometric analysis of the theory of effectuation (Sarasvathy, 2001) and the internationalisation of SMEs. Table 1 summarises the results. The number of publications reflects each author's productivity, and the number of citations shows each author's influence in this research area (Merigo and Urbano, 2016). Likewise, the number of citations reflects the intellectual structure of the field of study (Ding et al., 1999). The $\mathrm{H}$ index represents the importance of a specific group of articles (Martínez et al., 2014). The $\mathrm{H}$ index of the selected articles from WoS was 10. Thus, 10 of the 30 articles had been cited at least 10 times. The $\mathrm{H}$ index of the selected articles from Scopus was 13. The main difference between the number of citations from WoS and Scopus is explain by the fact that the Journal of Small Business and Enterprise Development, the European Business Review, the Journal of East European Management Studies and the Journal of International Entrepreneurship are not indexed on WoS but they are indexed on Scopus. It means that highly cited articles like Andersson (2011), Harms and Schiele (2012), Nowiński and Rialp (2013) and Crick and Crick (2014) and are not included on WoS.

Table 1. Overall summary of results 


\begin{tabular}{|l|c|c|}
\hline \multicolumn{1}{|c|}{ Criteria } & $\begin{array}{c}\text { Quantity / } \\
\text { WoS }\end{array}$ & $\begin{array}{c}\text { Quantity / } \\
\text { Scopus }\end{array}$ \\
\hline Number of published articles & 30 & 25 \\
\hline Total times cited & 398 & 689 \\
\hline Average citations per item & 13,27 & 27,56 \\
\hline H index & 10 & 13 \\
\hline Number of authors & 60 & 61 \\
\hline
\end{tabular}

Source: Compiled by the authors based on WoS and Scopus data.

According to Figure 1, research on the internationalisation of SMEs using the theory of the effectuation began 10 years after the publication of Sarasvathy's (2001) article. The first articles are characterised by the integration of the theory of effectuation to complement the Uppsala internationalisation model and the born global model. Schweizer et al. (2010) adapted the Uppsala internationalisation model (Johanson and Vahlne, 2009) by integrating the entrepreneurial process and principles of the theory of effectuation. Similarly, Andersson (2011) and Harms and Schiele (2012) integrated the theory of effectuation into the born global internationalisation model to explain the process of identifying international opportunities (Andersson, 2011) and the choice of entry mode (Harms and Schiele, 2012).

After the theory of effectuation had been integrated into the internationalisation models, scholars focused on explaining the internationalisation of SMEs using the entrepreneur, the decision-making process and the impact on the company as the units of analysis. This period is characterised by contributions to developing the theory of effectuation in reference to internationalisation (Matalamäki, 2017).

Like the number of publications per year, the number of citations has also grown, as Figure 2 shows. Typically, citations are used as a measure of influence (Zupic and Čater, 2015). Therefore, an increasing number of citations might indicate a snowball effect created by the influence of the field of study. It also reflects the importance that this field of research has acquired and the efforts of the academic community to further it and develop it. The articles with the greatest influence include 'An Effectual Approach to International Entrepreneurship: Overlaps, Challenges, and Provocative Possibilities', by Sarasvathy et al. (2014), 'Expect the unexpected": Implications of 
effective logic on the internationalisation process', by Kalinic et al. (2014), 'Strategic Decision-Making of a Born Global: A Comparative Study from Three Small Open Economies', by Nummela et al. (2014), and 'Effectuation and Networking of Internationalizing SMEs', by Galkina and Chetty (2015).

Figure 1. Number of publications per year

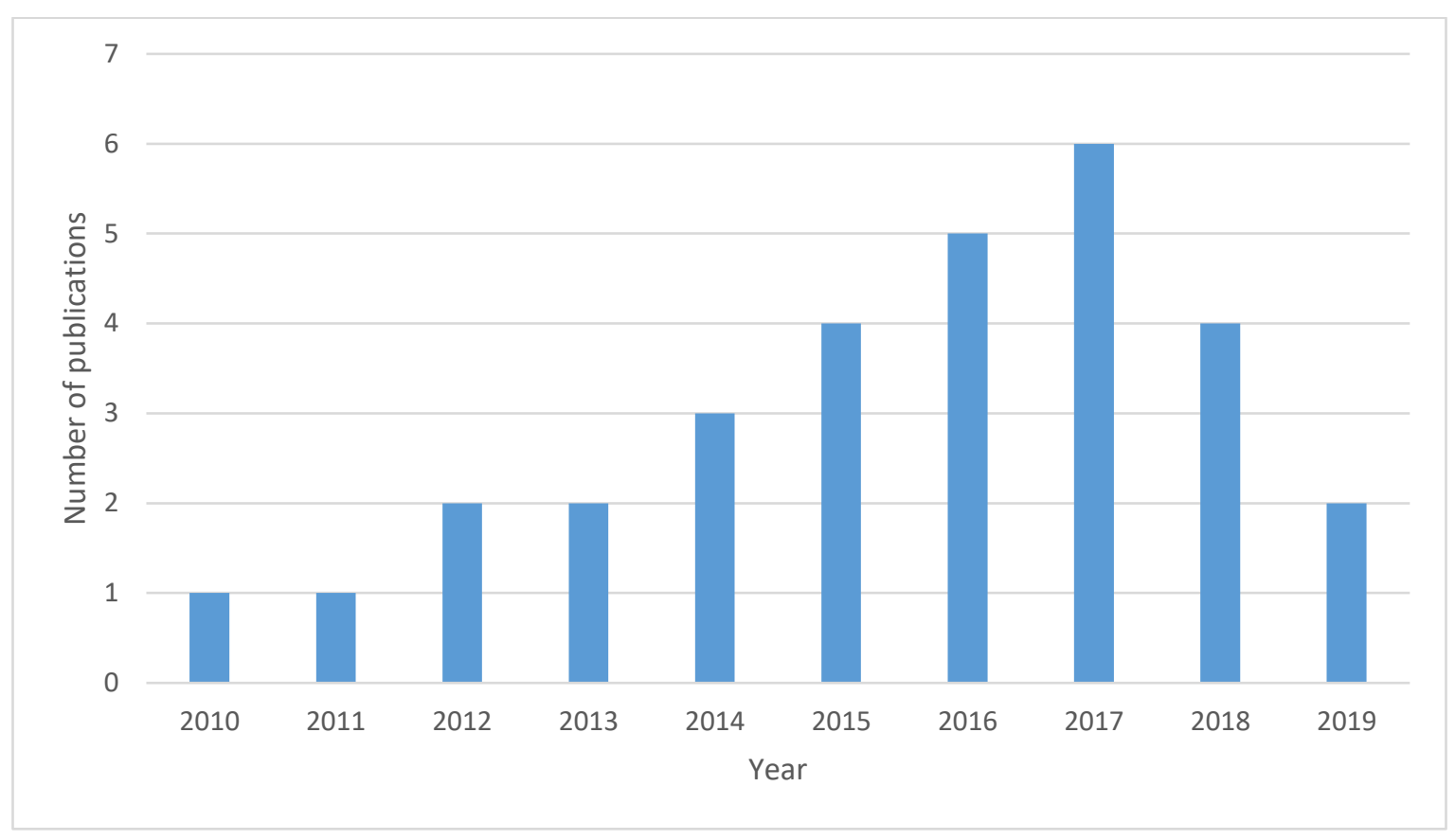

Source: Compiled by the authors based on WoS data.

Figure 2. Number of citations per year 


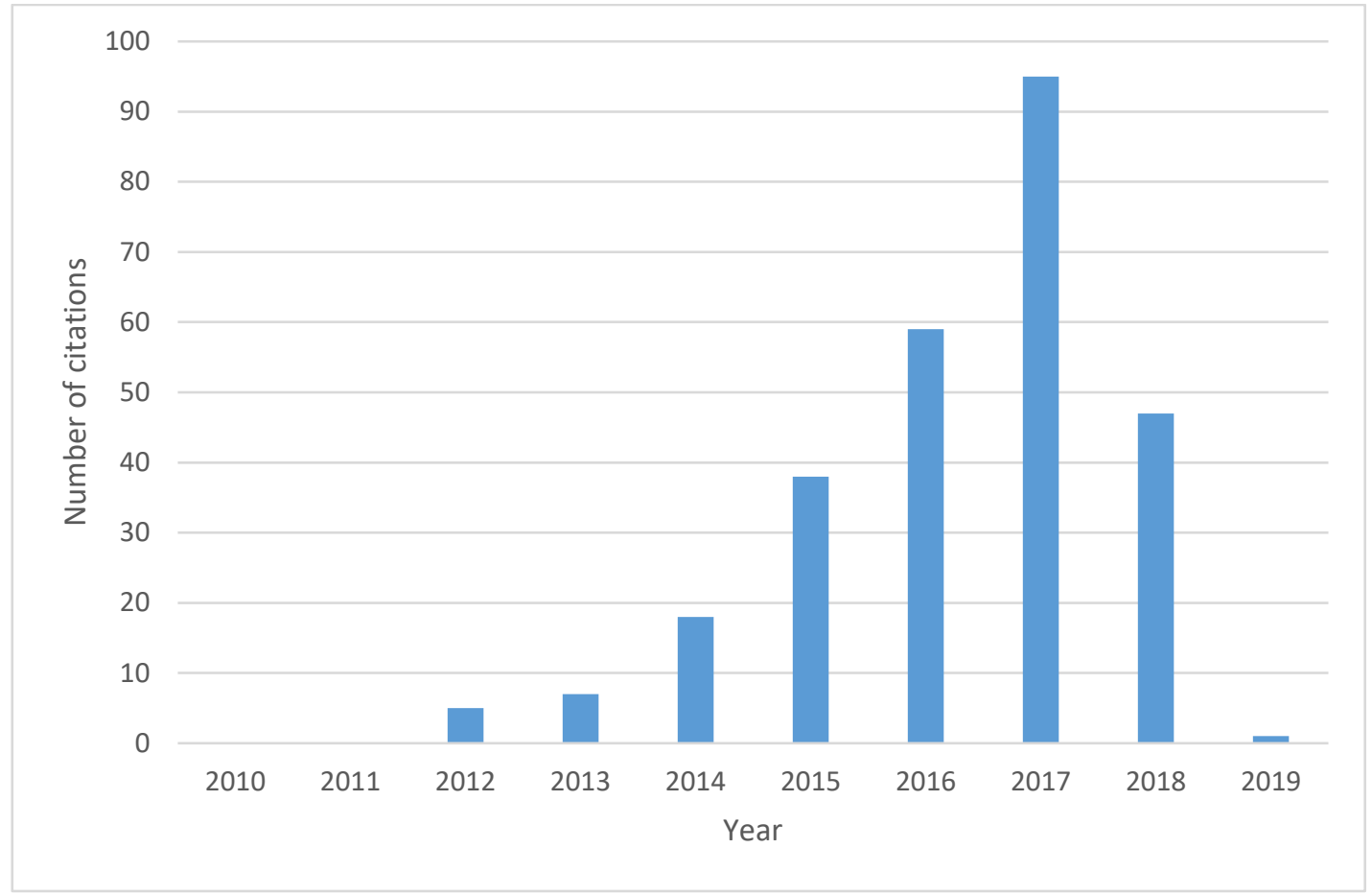

Source: Compiled by the authors based on WoS data.

\subsubsection{Most influential articles}

Table 2 shows the most influential articles, measured by the number of citations they have received in the journals included in WoS. The most influential article, 'An Effectual Approach to International Entrepreneurship: Overlaps, Challenges, and Provocative Possibilities', by Sarasvathy et al. (2014), has 76 citations on WoS and 86 citations on Scopus. This article can be used to identify potential areas of research for development by analysing the internationalisation of SMEs using the theory of effectuation. The following four articles report that the logic of effectuation enhances the internationalisation of SMEs. Gabrielsson and Gabrielsson (2013) analysed the effect of effectuation on the identification of international opportunities. Mort et al. (2012) analysed the impact of effectuation on marketing entrepreneurship. Kalinic et al. (2014) found that effectuation is crucial for entrepreneurs to overcome complex problems that arise during internationalisation. Finally, Galkina and Chetty (2015) integrates effectuation theory with the revisited Uppsala by introducing the concept of effectual networking. These five articles represent $62 \%$ of total citations 
on WoS and $46 \%$ of total citations on Scopus. The 10 articles in Table 2 represent $86 \%$ of total citations on WoS and $66 \%$ of total citations on Scopus.

Table 2. Most influential articles

\begin{tabular}{|c|c|c|c|c|}
\hline No. & Authors & Title of the article & $\begin{array}{l}\text { Total } \\
\text { citations } \\
\text { WoS }\end{array}$ & \begin{tabular}{|l|} 
Total \\
citations \\
Scopus
\end{tabular} \\
\hline 1 & $\begin{array}{l}\text { Sarasvathy et al. } \\
\text { (2014) }\end{array}$ & $\begin{array}{l}\text { An Effectual Approach to } \\
\text { International Entrepreneurship: } \\
\text { Overlaps, Challenges, and } \\
\text { Provocative Possibilities }\end{array}$ & 74 & 86 \\
\hline 2 & $\begin{array}{l}\text { Gabrielsson \& } \\
\text { Gabrielsson } \\
\text { (2013) }\end{array}$ & $\begin{array}{l}\text { A dynamic model of growth } \\
\text { phases and survival in } \\
\text { international business-to-business } \\
\text { new ventures: The moderating } \\
\text { effect of decision-making logic }\end{array}$ & 50 & 70 \\
\hline 3 & $\begin{array}{l}\text { Mort, } \\
\text { Weerawardena, } \\
\text { \& Liesch (2012) }\end{array}$ & $\begin{array}{l}\text { Advancing entrepreneurial } \\
\text { marketing Evidence from born } \\
\text { global firms }\end{array}$ & 41 & 61 \\
\hline 4 & $\begin{array}{l}\text { Kalinic, } \\
\text { Sarasvathy, \& } \\
\text { Forza (2014) }\end{array}$ & $\begin{array}{l}\text { 'Expect the unexpected': } \\
\text { Implications of effectual logic on } \\
\text { the internationalisation process }\end{array}$ & 44 & 55 \\
\hline 5 & $\begin{array}{l}\text { Galkina \& Chetty } \\
(2015)\end{array}$ & $\begin{array}{l}\text { Effectuation and Networking of } \\
\text { Internationalizing SMEs }\end{array}$ & 37 & 46 \\
\hline 6 & $\begin{array}{l}\text { Evers, } \\
\text { Andersson, \& } \\
\text { Hannibal (2012) }\end{array}$ & $\begin{array}{l}\text { Stakeholders and Marketing } \\
\text { Capabilities in International New } \\
\text { Ventures: Evidence from Ireland, } \\
\text { Sweden, and Denmark }\end{array}$ & 31 & 42 \\
\hline 7 & $\begin{array}{l}\text { Nummela et al. } \\
\text { (2014) }\end{array}$ & $\begin{array}{l}\text { Strategic Decision-Making of a } \\
\text { Born Global: A Comparative Study } \\
\text { From Three Small Open } \\
\text { Economies }\end{array}$ & 31 & 40 \\
\hline 8 & $\begin{array}{l}\text { Nowiński \& Rialp } \\
\text { (2013) }\end{array}$ & $\begin{array}{l}\text { Drivers and strategies of } \\
\text { international new ventures from a } \\
\text { Central European transition } \\
\text { economy }\end{array}$ & 21 & 32 \\
\hline 9 & $\begin{array}{l}\text { Chandra, Styles, } \\
\text { \& Wilkinson } \\
\text { (2015) }\end{array}$ & $\begin{array}{l}\text { Opportunity portfolio: Moving } \\
\text { beyond single opportunity } \\
\text { explanations in international } \\
\text { entrepreneurship research }\end{array}$ & 11 & 16 \\
\hline 10 & $\begin{array}{l}\text { Crick \& Crick } \\
(2016)\end{array}$ & $\begin{array}{l}\text { An appreciative inquiry into the } \\
\text { first export order }\end{array}$ & 2 & 4 \\
\hline
\end{tabular}


Source: Compiled by the authors based on WoS and Scopus data.

Table 3 lists the articles that were most cited by the 30 selected articles from WoS, the 25 articles from Scopus and the total number of citations in both databases. These articles are generally conceptual papers that provide the basis to develop the theory of effectuation and the internationalisation of companies. The most cited article, which has 28 (WoS) and 23 (Scopus) citations among the analysed articles, is 'Causation and Effectuation: Toward a Theoretical Shift from Economic Inevitability to Entrepreneurial Contingency', by Sarasvathy (2001). The theory of effectuation is formulated in this article. The fact that this article has 28 and 23 citations means that most of the selected articles in both databases cited it. The articles that follow in the list address the Uppsala internationalisation model (Johanson and Vahlne, 1977, 2009), the born global internationalisation model (Oviatt and McDougal, 1994), the incorporation of the theory of effectuation in the Uppsala internationalisation model (Schweizer et al., 2010), the incorporation of the theory of effectuation in the born global model (Andersson, 2011; Harms and Schiele, 2012), the incorporation of the theory of effectuation in the analysis of the internationalisation of SMEs (Kalinic et al., 2014; Sarasvathy et al., 2014), reviews of the international entrepreneurship literature (Jones and Coviello, 2005, Jones et al., 2011, Oviatt and McDougal, 2005), instruments and methods to measure effectuation (Chandler et al., 2011), and the method to formulate theories based on case studies (Eisenhardt, 1989). These 15 articles represent $52 \%$ of total citations from WoS.

Figure 3 shows the network of co-cited articles. This analysis identifies the cooccurrence relationship of two articles cited together by a third article. For the analysis of co-cited articles, only the articles that were cited at least five times were selected. The analysis was therefore performed for the 59 most co-cited articles from WoS. The network of co-cited articles shows the grouping of different articles in four clusters. The first cluster (red colour) comprises articles that present research on the internationalisation of SMEs and effectuation (e.g. Chandler 2011; Sarasvathy et al., 2014; Schweizer et al., 2010). The second cluster (green colour) consists of the most 
relevant articles on born globals (e.g. Coviello 2004; Jones and Coviello, 2005; Oviatt and McDougal, 1994, 2005; Weerawardena, 2007). The third cluster (blue colour) comprises articles of qualitative methods to develop the research field (e.g. Eisenhardt, 1989; Miles et al., 1994). The fourth cluster (yellow colour) comprises articles that contribute conceptually to the development of research on the internationalisation of SMEs (Coviello and Munro, 1997; Keupp and Gassmann, 2009). The relationship between these clusters shows that research on effectuation and the internationalisation of SMEs is mainly oriented towards the study of born global firms.

The conformation of these clusters is confirmed by the result of the co-occurrence analysis of the 53 articles that were most cited by the 25 selected articles from Scopus. As seen in figure 4, the first cluster (red colour) also consists of the articles that present research on the internationalisation of SMEs and effectuation. The second cluster (green colour) also comprises articles on born global. The only difference is the third cluster (blue colour) that comprises articles of qualitative methods and conceptual articles within the same cluster.

Table 3. Most cited articles

\begin{tabular}{|c|c|c|c|c|c|c|}
\hline No. & Authors & Title of the article & $\begin{array}{l}\text { No. of } \\
\text { citations } \\
\text { by the } 30 \\
\text { articles } \\
\text { from WoS }\end{array}$ & $\begin{array}{l}\text { No. of } \\
\text { citations } \\
\text { by the } 25 \\
\text { articles } \\
\text { from } \\
\text { scopus }\end{array}$ & $\begin{array}{l}\text { Total } \\
\text { citations } \\
\text { WoS }\end{array}$ & $\begin{array}{l}\text { Total } \\
\text { citations } \\
\text { Scopus }\end{array}$ \\
\hline 1 & $\begin{array}{l}\text { Sarasvathy } \\
\text { (2001) }\end{array}$ & $\begin{array}{l}\text { Causation and Effectuation: Toward a } \\
\text { Theoretical Shift from Economic } \\
\text { Inevitability to Entrepreneurial } \\
\text { Contingency }\end{array}$ & 28 & 23 & 1.506 & 1.720 \\
\hline 2 & $\begin{array}{l}\text { Johanson \& } \\
\text { Vahlne (1977) }\end{array}$ & $\begin{array}{l}\text { The Internationalisation Process of the } \\
\text { Firm-A Model of Knowledge } \\
\text { Development and Increasing Foreign } \\
\text { Market Commitments }\end{array}$ & 15 & 11 & 4.060 & $n / a$ \\
\hline 3 & $\begin{array}{l}\text { Andersson } \\
\text { (2011) }\end{array}$ & $\begin{array}{l}\text { International entrepreneurship, born } \\
\text { globals and the theory of effectuation }\end{array}$ & 15 & 19 & $n / a$ & 89 \\
\hline 4 & $\begin{array}{l}\text { Eisenhardt } \\
\text { (1989) }\end{array}$ & $\begin{array}{l}\text { Building Theories from Case Study } \\
\text { Research }\end{array}$ & 15 & 9 & 14.887 & $n / a$ \\
\hline
\end{tabular}




\begin{tabular}{|c|c|c|c|c|c|c|}
\hline 5 & $\begin{array}{l}\text { Jones, } \\
\text { Coviello, \& } \\
\text { Tang }(2011) \\
\end{array}$ & $\begin{array}{l}\text { International Entrepreneurship } \\
\text { research (1989-2009): A domain } \\
\text { ontology and thematic analysis }\end{array}$ & 14 & 9 & 346 & 457 \\
\hline 6 & $\begin{array}{l}\text { Sarasvathy et } \\
\text { al. (2014) }\end{array}$ & $\begin{array}{l}\text { An Effectual Approach to International } \\
\text { Entrepreneurship: Overlaps, } \\
\text { Challenges, and Provocative } \\
\text { Possibilities }\end{array}$ & 14 & 12 & 74 & 87 \\
\hline 7 & \begin{tabular}{|l} 
Oviatt \& \\
McDougal \\
(1994)
\end{tabular} & $\begin{array}{l}\text { Toward a Theory of International New } \\
\text { ventures }\end{array}$ & 14 & 15 & 1.553 & 113 \\
\hline 8 & $\begin{array}{l}\text { Chandler et } \\
\text { al. (2011) }\end{array}$ & $\begin{array}{l}\text { Causation and effectuation processes: } \\
\text { A validation study }\end{array}$ & 13 & 10 & 170 & 215 \\
\hline 9 & $\begin{array}{l}\text { Johanson \& } \\
\text { Vahlne } \\
(2009) \\
\end{array}$ & $\begin{array}{l}\text { The Uppsala internationalisation } \\
\text { process model revisited: From liability } \\
\text { of foreignness to liability of outsidership }\end{array}$ & 12 & 6 & 1.364 & 1.503 \\
\hline 10 & $\begin{array}{l}\text { Kalinic, } \\
\text { Sarasvathy, \& } \\
\text { Forza (2014) }\end{array}$ & $\begin{array}{l}\text { Expect the unexpected': Implications of } \\
\text { effectual logic on the } \\
\text { internationalisation process }\end{array}$ & 12 & 7 & 44 & 55 \\
\hline 11 & $\begin{array}{l}\text { Oviatt \& } \\
\text { McDougal } \\
(2005) \\
\end{array}$ & $\begin{array}{l}\text { Defining international entrepreneurship } \\
\text { and modeling the speed of } \\
\text { internationalisation }\end{array}$ & 11 & 6 & 644 & 787 \\
\hline 12 & $\begin{array}{l}\text { Harms \& } \\
\text { Schiele } \\
\text { (2012) }\end{array}$ & $\begin{array}{l}\text { Antecedents and consequences of } \\
\text { effectuation and causation in the } \\
\text { international new venture creation } \\
\text { process }\end{array}$ & 11 & 6 & $\mathrm{n} / \mathrm{a}$ & 73 \\
\hline 13 & $\begin{array}{l}\text { Jones \& } \\
\text { Coviello } \\
(2005) \\
\end{array}$ & $\begin{array}{l}\text { Internationalisation: Conceptualising an } \\
\text { Entrepreneurial Process of Behaviour } \\
\text { in Time }\end{array}$ & 11 & 8 & 447 & 550 \\
\hline 14 & $\begin{array}{l}\text { Schweizer, } \\
\text { Vahlne, \& } \\
\text { Johanson } \\
(2010) \\
\end{array}$ & $\begin{array}{l}\text { Internationalisation as an } \\
\text { entrepreneurial process }\end{array}$ & 10 & 6 & $\mathrm{n} / \mathrm{a}$ & 113 \\
\hline 15 & $\begin{array}{l}\text { Wiltbank, } \\
\text { Dew, Read, \& } \\
\text { Sarasvathy } \\
(2006)\end{array}$ & $\begin{array}{l}\text { What to do next? The case for non- } \\
\text { predictive strategy }\end{array}$ & 10 & 4 & 200 & 242 \\
\hline
\end{tabular}

Source: Compiled by the authors based on WoS and Scopus data. 


\section{Figure 3. Network of co-citation of articles}

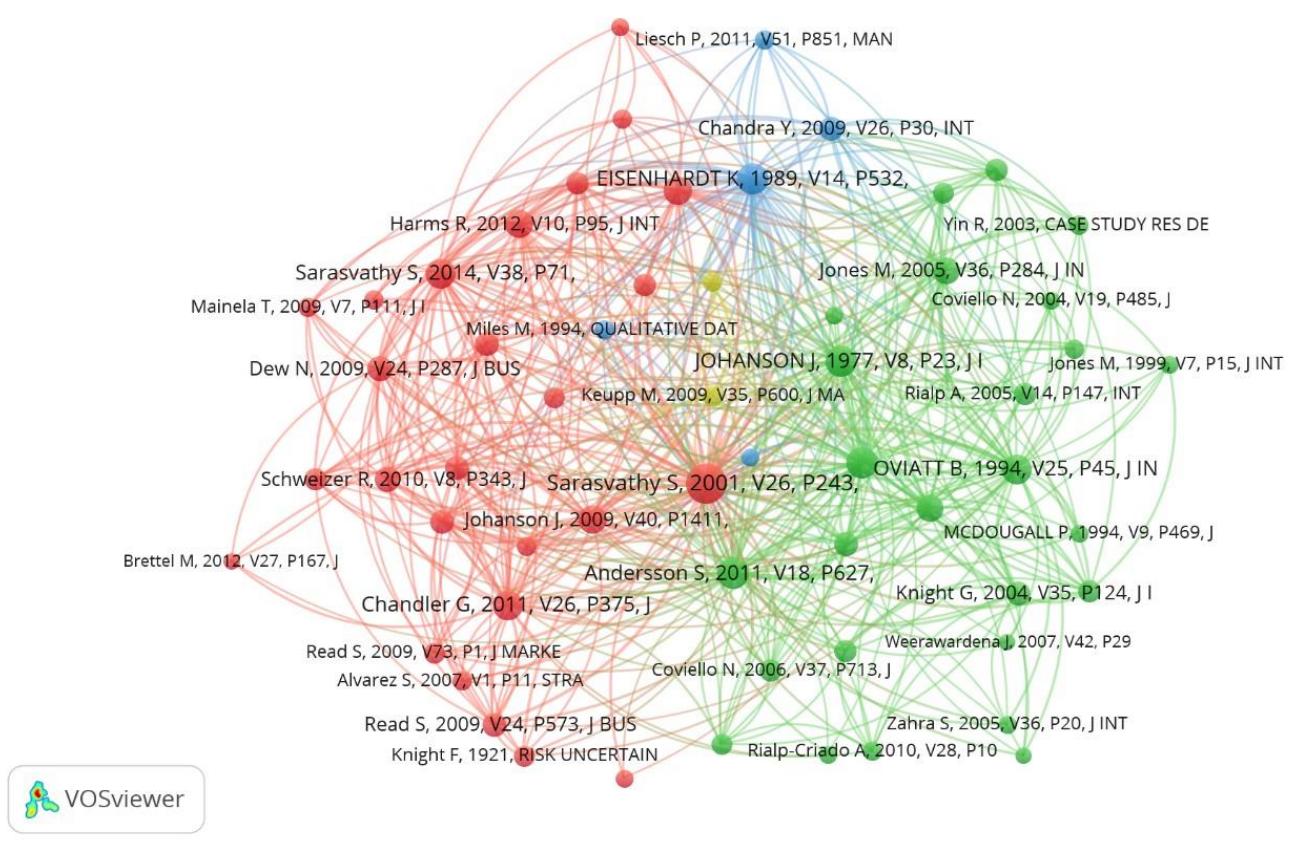

Source: VOSviewer based on WoS data.

Figure 4. Network of co-citation of articles

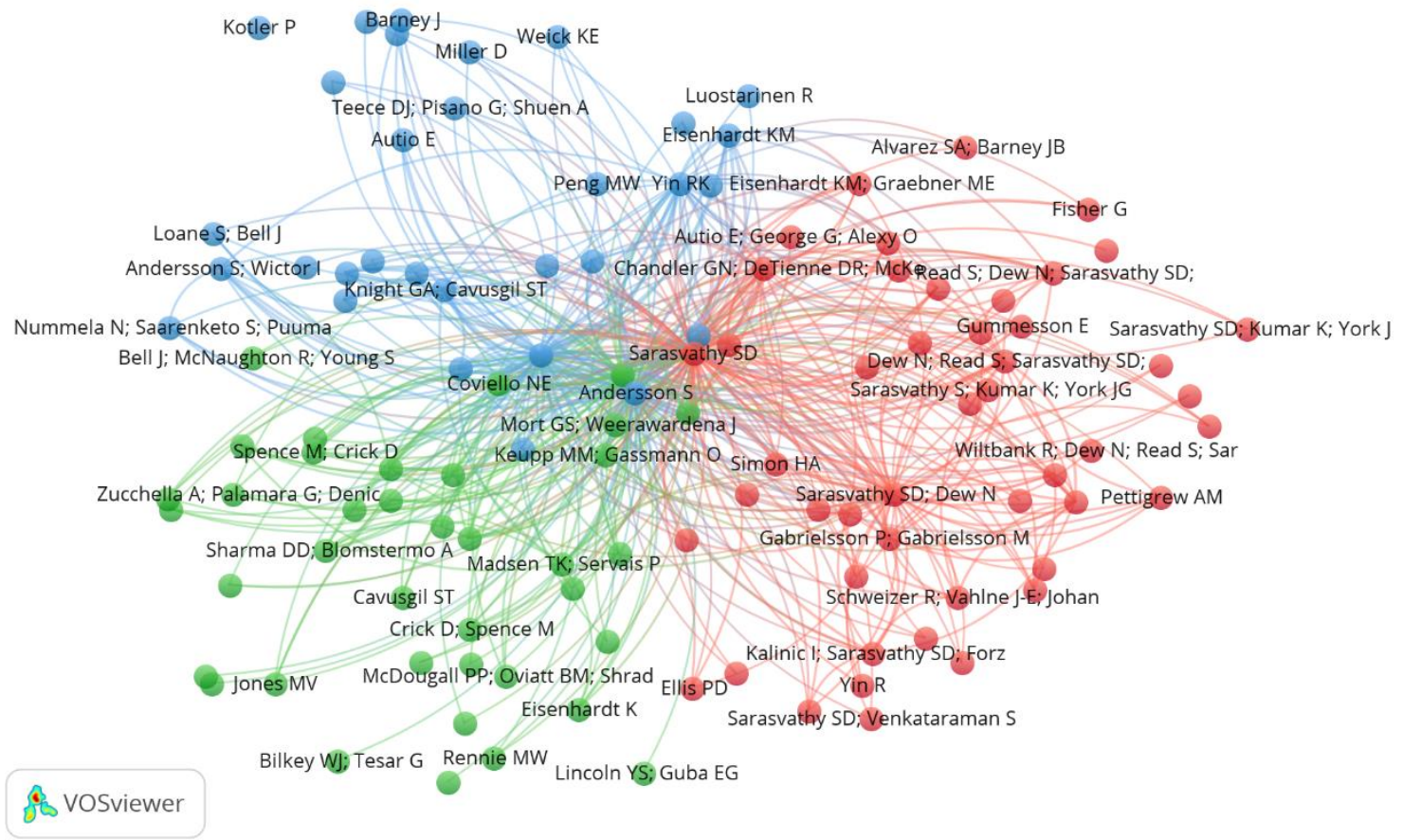


Source: VOSviewer based on Scopus data.

\subsubsection{Most influential authors}

Table 4 shows the ranking of the 20 most influential authors in the development of this research area. They were selected according to the number of citations that they have received in WoS journals. The most influential author is Saras Sarasvathy, with 71 citations, which is equivalent to $10 \%$ of all citations of the selected articles. Through two articles, this author lays the foundations to develop international entrepreneurship based on the author's theory (Kalinic et al., 2014; Sarasvathy et al., 2014). Next in the list are Suresh Bhagavatula, K. Kumar and Jeffrey York, with 46 citations each. These authors, together with Saras Sarasvathy, wrote the article 'An Effectual Approach to International Entrepreneurship: Overlaps, Challenges, and Provocative Possibilities', where they discuss four knowledge gaps that other authors have identified for the development of international entrepreneurship and explain how the theory of effectuation contributes to filling these gaps. In the fifth and sixth positions are Peter Gabrielsson and Mika Gabrielsson, with 39 and 36 citations, respectively. These citations are mainly for the article 'A dynamic model of growth phases and survival in international business-to-business new ventures: The moderating effect of decision-making logic', where the role of effectuation in the identification of international opportunities is explained. The 31 citations received by Peter Liesch, Gillian Sullivan Mort and Jay Weerawardena are for the article 'Advancing entrepreneurial marketing: Evidence from Born Global Firms', where they explain how the use of effectuation improves entrepreneurial marketing capabilities and therefore company performance in foreign markets. The most efficient authors are Suresh Bhagavatula; Kumar, K., and Jeffrey York with 46 citations per article.

Regarding the number of citations in Scopus journals, the most influential author is Svante Andersson, with 85 citations, which is equivalent to $12 \%$ of all citations of the selected articles from Scopus. The difference consists in the fact that Scopus database includes the author's article 'Antecedents and consequences of 
effectuation and causation in the international new venture creation process' which has 73 cites, but the article is not included on WoS. The remaining articles show a similar tendency of those from WoS.

Table 4. Most influential authors

\begin{tabular}{|c|c|c|c|c|c|c|c|}
\hline \multirow[b]{2}{*}{ No. } & \multirow[b]{2}{*}{ Author } & \multicolumn{3}{|c|}{ Wos } & \multicolumn{3}{|c|}{ Scopus } \\
\hline & & $\begin{array}{c}\text { No of } \\
\text { Citations } \\
\text { by the } \\
\text { analyzed } \\
\text { articles }\end{array}$ & $\begin{array}{c}\text { No of } \\
\text { articles }\end{array}$ & $\begin{array}{l}\text { Efficiency } \\
\text { (No. of } \\
\text { citations / } \\
\text { No. of } \\
\text { articles) }\end{array}$ & $\begin{array}{c}\text { No of } \\
\text { Citations } \\
\text { by the } \\
\text { analyzed } \\
\text { articles }\end{array}$ & $\begin{array}{c}\text { No of } \\
\text { articles }\end{array}$ & $\begin{array}{c}\text { Efficiency } \\
\text { (No. of } \\
\text { citations / } \\
\text { No. of } \\
\text { articles) }\end{array}$ \\
\hline 1 & $\begin{array}{l}\text { Sarasvathy, } \\
\text { Saras D. }\end{array}$ & 71 & 2 & 36 & 141 & 3 & 47 \\
\hline 2 & $\begin{array}{l}\text { Bhagavatula, } \\
\text { Suresh }\end{array}$ & 46 & 1 & 46 & 86 & 2 & 43 \\
\hline 3 & Kumar, K. & 46 & 1 & 46 & 86 & 2 & 43 \\
\hline 4 & York, Jeffrey G. & 46 & 1 & 46 & 85 & 1 & 85 \\
\hline 5 & $\begin{array}{l}\text { Gabrielsson, } \\
\text { Peter }\end{array}$ & 39 & 2 & 20 & 88 & 2 & 44 \\
\hline 6 & $\begin{array}{l}\text { Gabrielsson, } \\
\text { Mika }\end{array}$ & 36 & 1 & 36 & 70 & 1 & 70 \\
\hline 7 & Liesch, Peter & 31 & 1 & 31 & $\mathrm{n} / \mathrm{a}$ & $\mathrm{n} / \mathrm{a}$ & $\mathrm{n} / \mathrm{a}$ \\
\hline 8 & $\begin{array}{l}\text { Mort, Gillian } \\
\text { Sullivan }\end{array}$ & 31 & 1 & 31 & $\mathrm{n} / \mathrm{a}$ & $\mathrm{n} / \mathrm{a}$ & $\mathrm{n} / \mathrm{a}$ \\
\hline 9 & $\begin{array}{l}\text { Weerawardena, } \\
\text { Jay }\end{array}$ & 31 & 1 & 31 & $\mathrm{n} / \mathrm{a}$ & $\mathrm{n} / \mathrm{a}$ & $\mathrm{n} / \mathrm{a}$ \\
\hline 10 & Evers, Natasha & 25 & 1 & 25 & 49 & 2 & 25 \\
\hline 11 & Forza, Cipriano & 25 & 1 & 25 & 55 & 1 & 55 \\
\hline 12 & Hannibal, Martin & 25 & 1 & 25 & 49 & 2 & 25 \\
\hline 13 & Kalinic, Igor & 25 & 1 & 25 & 55 & 1 & 55 \\
\hline 14 & \begin{tabular}{|l} 
Andersson, \\
Svante
\end{tabular} & 23 & 1 & 23 & 191 & 3 & 64 \\
\hline 15 & Chetty, Sylvie & 22 & 1 & 22 & 46 & 1 & 46 \\
\hline 16 & Galkina, Tamara & 22 & 1 & 22 & 51 & 2 & 26 \\
\hline 17 & Jokela, Paivi & 21 & 1 & 21 & 40 & 1 & 40 \\
\hline 18 & Loane, Sharon & 21 & 1 & 21 & 40 & 1 & 40 \\
\hline 19 & Nummela, Niina & 21 & 1 & 21 & 40 & 1 & 40 \\
\hline 20 & Saarenketo, Sami & 21 & 1 & 21 & 40 & 1 & 40 \\
\hline
\end{tabular}

Source: Compiled by the authors based on WoS and Scopus data.

Co-author analysis reveals the structure of scientific networks based on collaborations (Zupic and Čater, 2015). Hence, this analysis identifies the academic 
networks of authors in a specific research area. Analysis of the relationship between the most influential co-authors shows the absence of academic collaboration. Only three relationships are identified between the following authors of the 30 selected articles: Saras Sarasvathy, Shameen Prashantham, Suresh Bhagavatula, K. Kumar, Jeffrey York, Igor Kalinic and Cipriano Forza. This relationship corresponds to the articles "Expect the unexpected": Implications of effective logic on the internationalisation process', 'An Effectual Approach to International Entrepreneurship: Overlaps, Challenges, and Provocative Possibilities' and the recent article 'Effectuation, network-building and internationalisation speed'. Saras Sarasvathy, Suresh Bhagavatula and K. Kumar are the only co-authors of these articles. The other nodes illustrate separate co-authorship of the most cited articles. Figure 5 illustrates this scientific collaboration network in detail. The absence of academic collaboration is confirmed by the co-author analysis of the articles from Scopus. Exactly the same relations was found.

This situation changes when analysing the network of co-cited authors. The analysis of co-cited authors identifies the intellectual structure of a specific research area (Zupic and Čater, 2015). We only considered authors with more than five co-citations in WoS journals. As Figure 6 shows, the intellectual structure consists of three clusters of authors. The first (green colour) comprises authors who research effectuation and internationalisation (e.g. Sylvie Chetty, Saras Sarasvathy, Tamara Galinka, Mika Gabrielsson and Nina Nummela), the second (red colour) consists of international entrepreneurship scholars (e.g. David Crick, Alex Rialp, Erkko Autio and Jim Bell), and the third one (blue colour) consists of entrepreneurship scholars (e.g. Robert Wiltbank and Nicole Coviello). The analysis of co-cited authors from Scopus articles confirmed the findings. Figure 7 displays these clusters in detail. 
Figure 5. Network of co-authors: related nodes

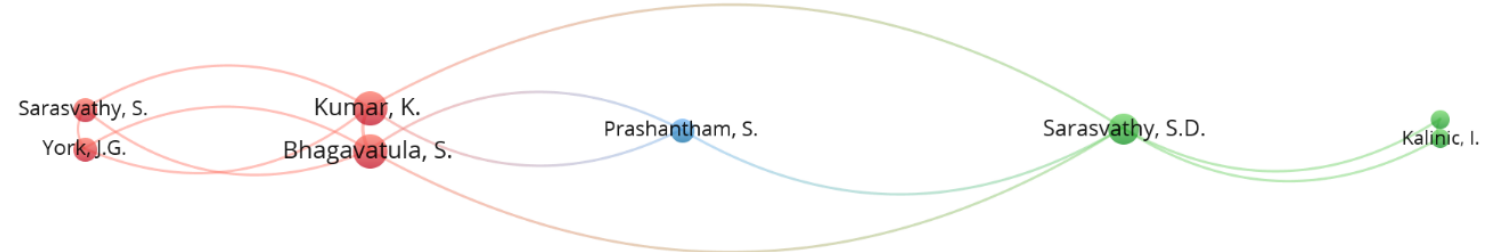

\& Vosviewer

Source: VOSviewer based on WoS and Scopus data.

Figure 6. Network of co-cited authors

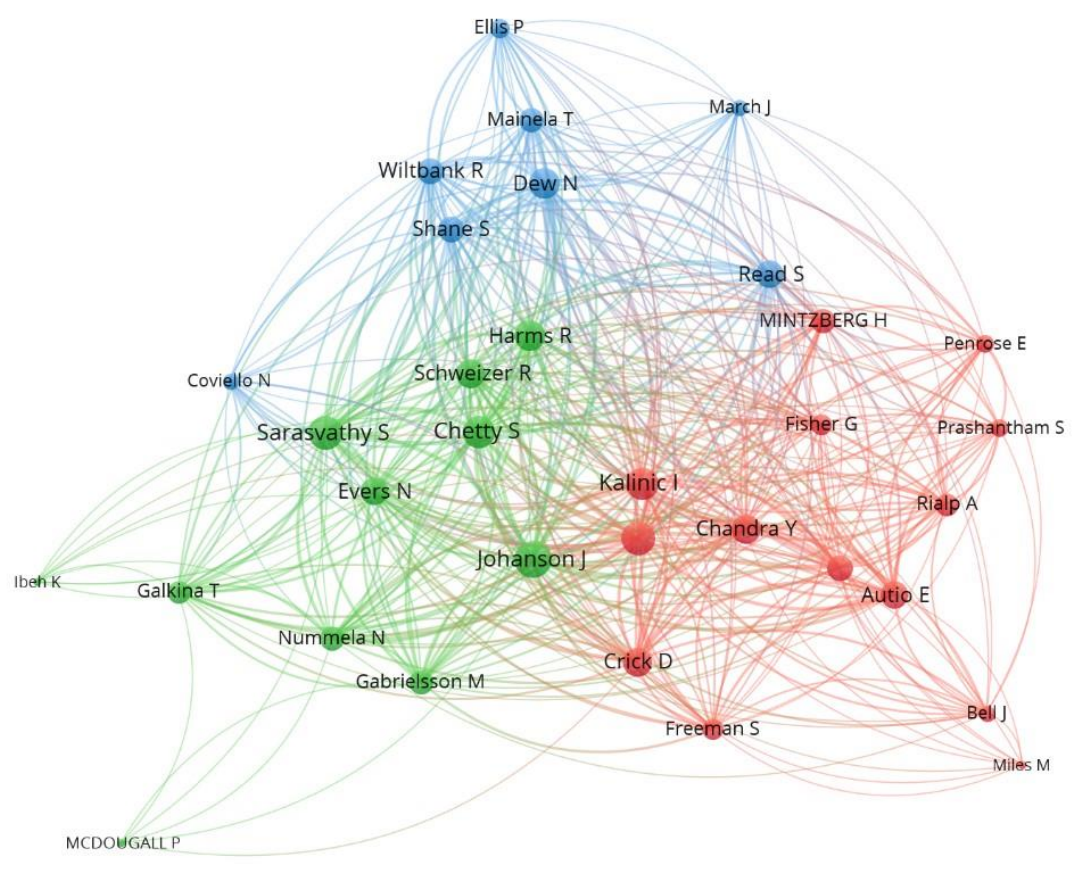

Source: VOSviewer based on WoS data. 
Figure 7. Network of co-cited authors

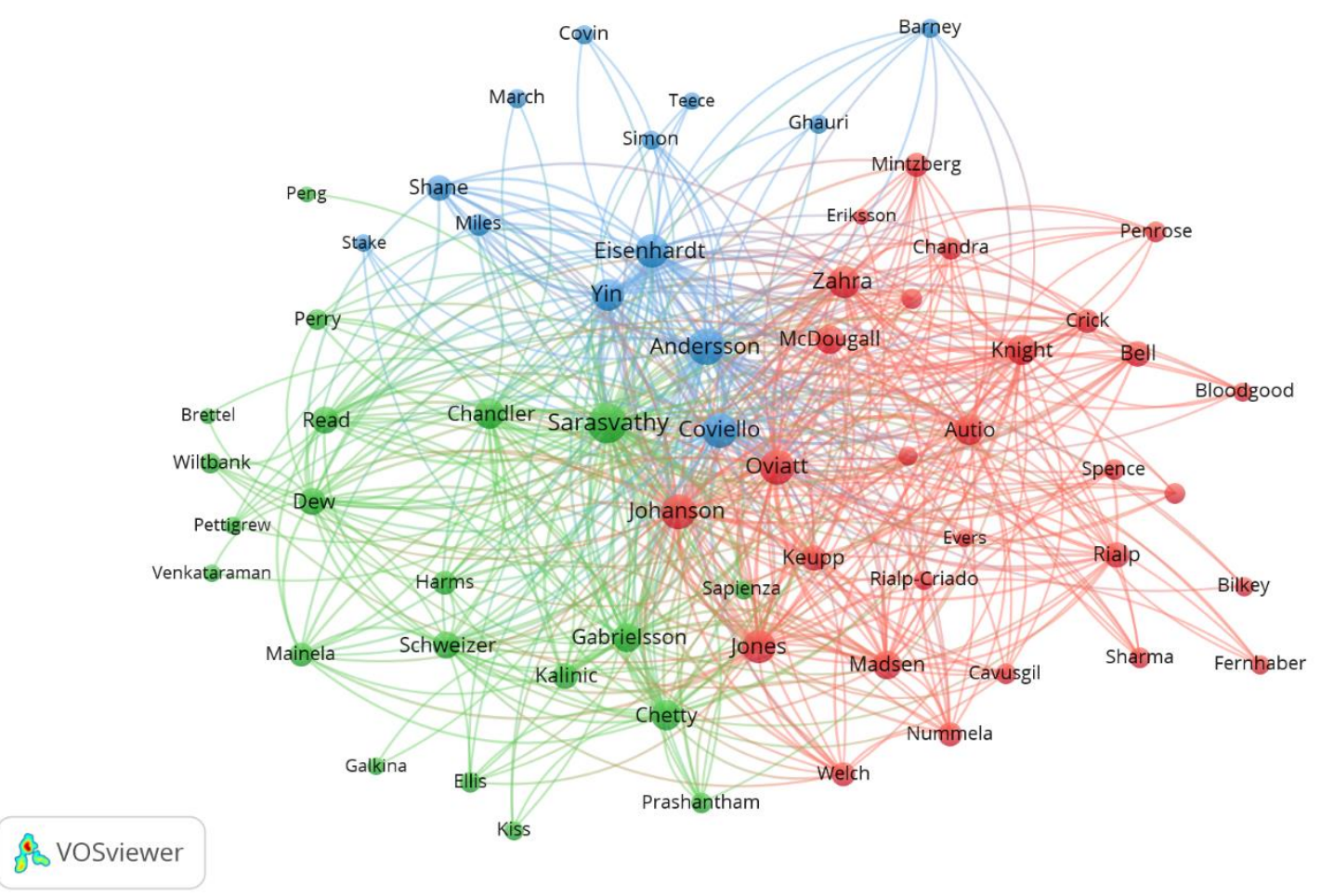

Source: VOSviewer based on Scopus data.

\subsubsection{Most influential journals}

Table 5 shows the five most influential journals. These five journals account for $91 \%$ of all citations. Accordingly, research on internationalisation under the theory of effectuation is concentrated in a few journals. These journals are Entrepreneurship Theory and Practice, with 48 citations, Management International Review, with 43 citations, Industrial Marketing Management, with 39 citations, European Journal of Marketing, with 31 citations, and International Business Review, with 25 citations. Of these journals, the most efficient is European Journal of Marketing, followed by International Business Review.

Comparing the most influential journals with the most influential authors reveals a relationship. For example, the two articles by Saras Sarasvathy were published in Entrepreneurship Theory and Practice and International Business Review. Peter 
Gabrielsson's research was published in Industrial Marketing Management. Sullivan Mort's research was published in European Journal of Marketing. Tamara Galinka and Nina Nummela's research was published in Management International Review.

Figure 8 shows the network of co-cited journals. Only the journals with at least five co-citations were considered in this analysis. This network consists of two clusters. The first cluster comprises journals that specialise in small businesses and entrepreneurship (i.e. Entrepreneurship Theory and Practice, Journal of Business Venturing, Small Business Economics Journal and Journal of Small Business Management). The second cluster comprises journals that specialise in administration and management (i.e. Journal of International Business Studies, Academy of Management, Academy of Management Review and Harvard Business Review).

Table 5. Most influential journals

\begin{tabular}{|c|l|c|c|c|}
\hline No. & \multicolumn{1}{|c|}{ Journal } & $\begin{array}{c}\text { No. of } \\
\text { citations }\end{array}$ & $\begin{array}{c}\text { No. of } \\
\text { articles }\end{array}$ & $\begin{array}{c}\text { Efficiency (No. } \\
\text { of citations / No. } \\
\text { of articles) }\end{array}$ \\
\hline 1 & $\begin{array}{l}\text { Entrepreneurship Theory and } \\
\text { Practice }\end{array}$ & 48 & 2 & 24 \\
\hline 2 & Management International Review & 43 & 2 & 21,5 \\
\hline 3 & Industrial Marketing Management & 39 & 3 & 13 \\
\hline 4 & European Journal of Marketing & 31 & 1 & 31 \\
\hline 5 & International Business Review & 25 & 1 & 25 \\
\hline
\end{tabular}

Source: Compiled by the authors based on WoS data. 


\section{Figure 8. Network of co-cited journals}

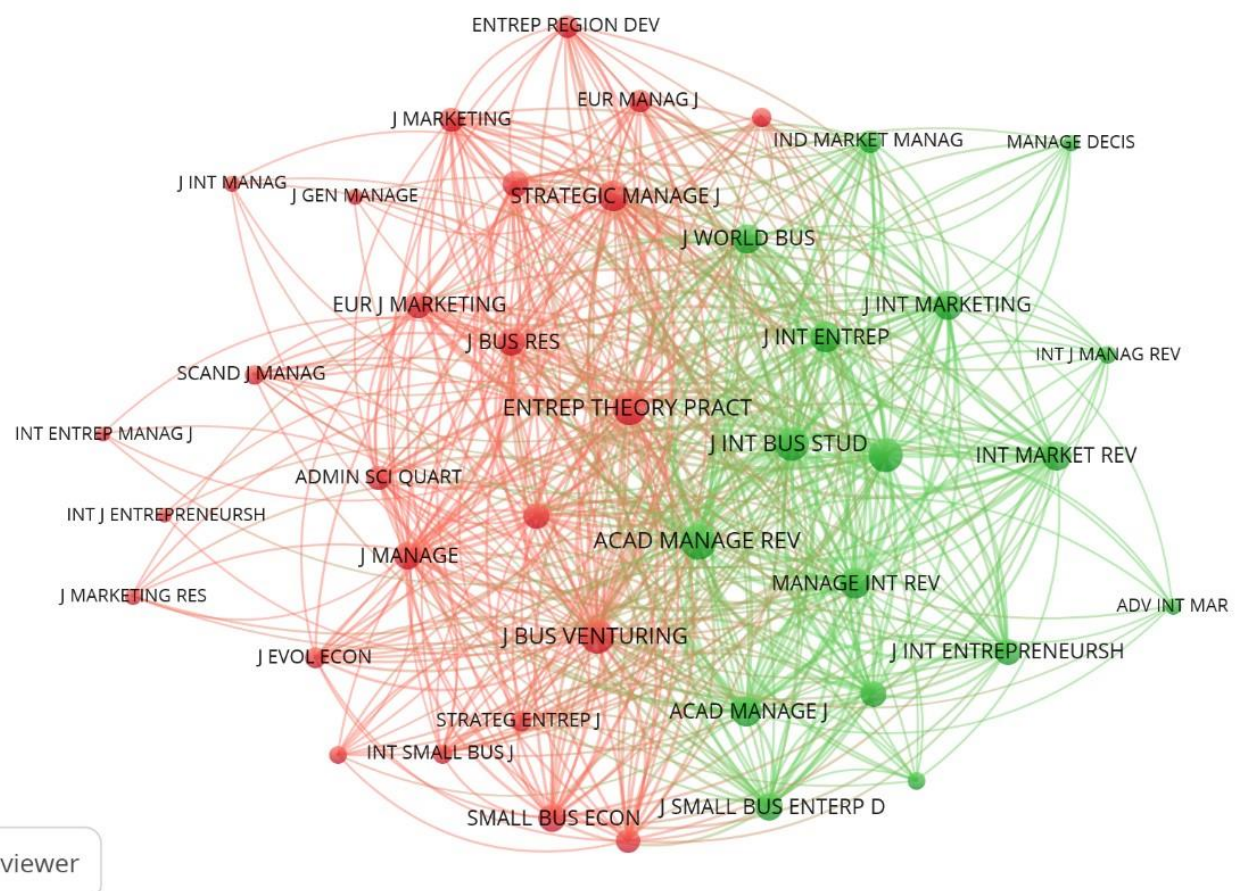

Source: VOSviewer based on WoS data.

Finally, Table 6 shows the keywords that are most used by the 30 selected articles. Figure 9 shows the keyword network. By identifying the most-used keywords and their relationship, the main concepts that are used to develop the research field can be identified (Zupic and Čater, 2015). The analysis shows that research on internationalisation and the theory of effectuation is determined by an understanding of effectuation, international entrepreneurship, new international companies, causation, internationalisation, decision making, born global companies and SMEs. These words, in turn, are related to the definition of effectuation.

Table 6. Most-used keywords

\begin{tabular}{|c|l|c|}
\hline No. & \multicolumn{1}{|c|}{ Keywords } & $\begin{array}{c}\text { No. of times } \\
\text { used }\end{array}$ \\
\hline 1 & Effectuation & 12 \\
\hline 2 & International entrepreneurship & 6 \\
\hline 3 & International new ventures & 6 \\
\hline
\end{tabular}




\begin{tabular}{|c|l|c|}
4 & Causation & 5 \\
\hline 5 & Internationalisation & 5 \\
\hline 6 & Decision-making & 4 \\
\hline 7 & Internationalisation & 4 \\
\hline 8 & International new venture & 3 \\
\hline 9 & Born globals & 3 \\
\hline 10 & SMEs & 3 \\
\hline
\end{tabular}

Source: Compiled by the authors based on WoS data.

Figure 9. Keywords network

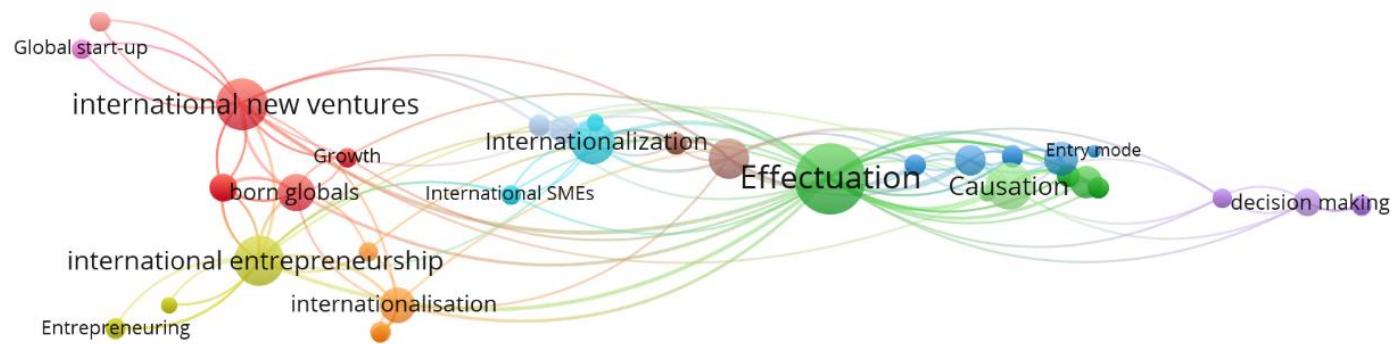

Source: VOSviewer based on WoS data.

\subsubsection{Conceptual structure}

Using Tree of Science software (Robledo Giraldo et al., 2014) and the previously analysed data from WoS and Scopus, we produced the tree of science for the internationalisation of SMEs and the theory of effectuation. This tree has three categories. The first is the root, which contains the articles that provide the theoretical and conceptual foundations for this area of research. The second category is the trunk, which consists of the articles that lend structure to this area. 
The third category consists of the leaves, which is made up of the most recent articles that enable the identification of trends in intellectual development. Figure 10 shows the articles that form the tree of science.

Figure 10. Tree of Science

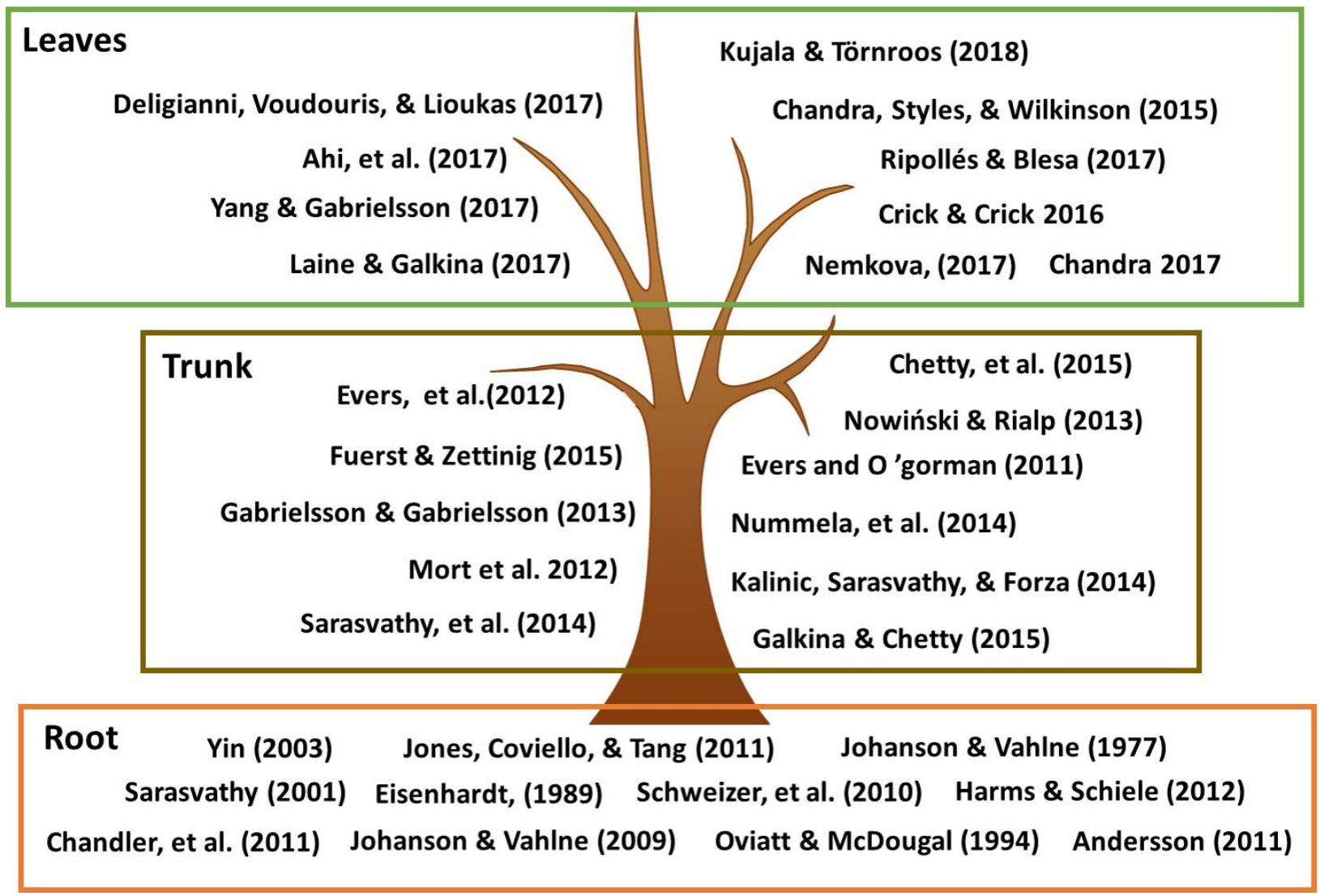

Source: Tree of Science based on WoS and Scopus data.

The articles that provide the foundations of the internationalisation of SMEs and the theory of effectuation are mostly classified as conceptual articles. These articles show that this area is conceptually based on the theory of effectuation (Sarasvathy, 2001), born globals and analysis of born globals using the theory of effectuation (Andersson, 2011; Harms and Schiele, 2012; Oviatt and McDougal, 1994), the Uppsala model and analysis of this model using the theory of effectuation (Johanson 
and Vahlne, 1977, 2009; Schweizer et al., 2010), international entrepreneurship (Jones et al., 2011) and theory creation based on case studies (Eisenhardt, 1989; Yin, 2003). The only qualitative article is by Chandler et al. (2011), who proposed an instrument to measure effectuation. This instrument comprises 20 elements that enable identification of causation, experimentation, affordable loss, flexibility and pre-agreements.

The articles that lend structure to this research field are classified into five areas. The first area consists of articles that focus on understanding the decision-making process of entrepreneurs during internationalisation (Chetty et al., 2015; Kalinic et al., 2014; Nummela et al., 2014). Chetty et al. (2015) found that entrepreneurs tend to interweave effectuation and causation logics when selecting a foreign market and entry mode. Kalinic et al. (2014) argued that switching from a causal to an effectuation logic boosts commitment in a foreign market. Likewise, Nummela et al. (2014) showed that, in the long term, born globals switch their decision making from effectual to causal.

The second area corresponds to articles that investigate international entrepreneurship based on the theory of effectuation (Nowiński and Rialp, 2013; Sarasvathy et al., 2014). Nowiński and Rialp (2013) showed that international entrepreneurs are expected to use effectuation logic. Sarasvathy et al. (2014) analysed the international entrepreneurship framework through the lens of effectuation theory, suggesting possibilities for further research.

The third area comprises articles that link entrepreneurial marketing to the theory of effectuation (Evers et al., 2012; Mort et al., 2012). For instance, Evers et al. (2012) illustrated how born globals use effectuation to develop marketing capabilities. Likewise, Mort et al. (2012) showed that born global firms that apply effectuation to entrepreneurial marketing decision have superior performance. 
The fourth area comprises articles that explore the impact of the logic of effectuation on knowledge acquisition, identification of international opportunities and networking (Evers and O'Gorman, 2011; Fuerst and Zettinig, 2015; Galkina and Chetty, 2015). Evers and O'Gorman (2011) showed that effectuation logic helps firms identify foreign market opportunities. Similarly, Galkina and Chetty (2015) concluded that effectuation focuses on partnerships to identify international opportunities. Finally, Fuerst and Zettinig (2015) identified the dynamics of knowledge creation in international new ventures. The three articles that belong to the fourth area integrate network theory into their analyses.

Finally, the fifth area comprises articles that examine the impact of the logic of effectuation on the growth and survival of SMEs in international markets (Gabrielsson and Gabrielsson, 2013). Specifically, Gabrielsson and Gabrielsson (2013) investigated how effectual logic moderates the growth and survival of international new ventures. The 11 articles that make up this structure are based on qualitative studies, with an average of five case studies each. In $88 \%$ of cases, they refer to developed economies. The countries with the highest representation in the studies are Finland and New Zealand, with 25\% and 19\% representation, respectively. The two articles that centre on developing economies are those by Fuerst and Zettinig (2015) and Sarasvathy et al. (2014), who studied companies in Colombia and India, respectively.

The most recent articles show that research on the internationalisation of SMEs and the theory of effectuation is being oriented towards furthering research in the five areas that give structure to this field. The first area seeks to understand entrepreneurs' decision-making processes. The academic discussion is based on understanding when and why companies exchange the logic of effectuation for the logic of causation. For example, Ahi et al. (2017) showed that companies use effectuation logic to enter the international market and then replace this logic with causation. In contrast, Crick and Crick (2016) found that the manager's team affects the company's decision making, which evolves from the logic of effectuation to the 
logic of causation. Similarly, Laine and Galkina (2017) found that although companies use effectuation and causation logics simultaneously, institutional uncertainty increases the use of effectuation.

Regarding the second area, Nemkova (2017) noted that effectuation and creativity explain the agility with which companies internationalise. By studying companies from Ghana, Kujala and Törnroos (2018) observed that the effectuation and capabilities of companies explain their internationalisation. These two studies contribute to developing international entrepreneurship and the theory of effectuation. Regarding research that links entrepreneurial marketing with effectuation, Yang and Gabrielsson (2017) showed that this relationship has positive effects on market creation, the co-creation of value, proactivity, innovation, risk management, the leveraging of resources and the creation of relationships with the client.

The main focus of the fourth area is to further our understanding of the impact of effectuation logic on the identification of international opportunities and the creation of networks. Chandra et al. (2015) showed that the logic of effectuation is evident in the processes of opportunity discovery and the development of product prototypes. When this process ends, the use of causation is more evident. Chandra (2017) contributed to the development of this area by proposing a model to broaden the scope of the process through three rules for evaluating opportunities: simple, revised and complex. Ripollés and Blesa (2017) also discovered that using effectuation logic to create networks positively affects the first stage of internationalisation. Finally, the article that probes into the impact of effectuation logic on the growth and survival of SMEs in international markets shows that the logic of effectuation positively affects the diversification of products and the performance of nascent companies (Deligianni et al., 2017). The analysis shows that $80 \%$ of the most recent articles (leaves in the tree of science) use qualitative methodologies, and although they generally focus on companies in developed economies, new countries such as Spain, Greece, Italy and the United Kingdom are also studied. 
Following the method proposed by Edmondson and McManus (2007) to identify the degree of development of the research field, we conclude that the explanation of internationalisation using the theory of effectuation is in a nascent stage for the following reasons. First, the conceptual structure shows that $88 \%$ of the articles are conceptual or qualitative. Second, as new research sub-areas are explored (e.g. identification of international opportunities, entrepreneurial marketing and company capabilities), new constructs are created. Apparently, the only validated instrument to measure generic effectuation is the instrument proposed by Chandler et al. (2011). Third, most data collection methods correspond to in-depth interviews. This evidence suggests that research on the internationalisation of SMEs' and the theory of effectuation is in an early stage of development (Edmondson and McManus, 2007). Table 7 displays a summary of articles in the tree of science of the internationalisation of SMEs and the theory of effectuation.

Table 7. Summary of articles in the tree of science of the internationalisation of SMEs and the theory of effectuation

\begin{tabular}{|c|l|l|c|}
\hline Clasification & \multicolumn{1}{|c|}{ Author(s) } & \multicolumn{1}{|c|}{ Main Findings } & $\begin{array}{c}\text { Kinds of } \\
\text { Research }\end{array}$ \\
\hline Root & Andersson (2011) & $\begin{array}{l}\text { The effectuation logic improves the } \\
\text { explanation of the } \\
\text { internationalisation of born global } \\
\text { companies. }\end{array}$ & $\begin{array}{c}\text { Conceptual } \\
\text { Article }\end{array}$ \\
\hline Root & $\begin{array}{l}\text { Chandler, } \\
\text { DeTienne, } \\
\text { McKelvie, \& } \\
\text { Mumford (2011) }\end{array}$ & $\begin{array}{l}\text { Creates an instrument with sub- } \\
\text { dimensions to measure the } \\
\text { effectuation and the causation. }\end{array}$ & $\begin{array}{c}\text { Qualitative } \\
\text { Study }\end{array}$ \\
\hline Root & Eisenhardt (1989) & $\begin{array}{l}\text { Proposes 8 steps to formulate } \\
\text { theories from the case study. }\end{array}$ & $\begin{array}{c}\text { Conceptual } \\
\text { Article }\end{array}$ \\
\hline Root & $\begin{array}{l}\text { Harms \& Schiele } \\
(2012)\end{array}$ & $\begin{array}{l}\text { Experienced entrepreneurs tend to } \\
\text { use effectuation instead of } \\
\text { causation, and do not have a } \\
\text { predetermined entry mode. }\end{array}$ & $\begin{array}{c}\text { Conceptual } \\
\text { Article }\end{array}$ \\
\hline Root & $\begin{array}{l}\text { Johanson \& Vahlne } \\
(1977)\end{array}$ & $\begin{array}{l}\text { Companies are internationalized } \\
\text { following a gradual process. }\end{array}$ & $\begin{array}{c}\text { Conceptual } \\
\text { Article }\end{array}$ \\
\hline
\end{tabular}




\begin{tabular}{|c|c|c|c|}
\hline Root & $\begin{array}{l}\text { Johanson \& Vahlne } \\
(2009)\end{array}$ & $\begin{array}{l}\text { The position of the company within } \\
\text { the network, the knowledge, and } \\
\text { the recognition of opportunities } \\
\text { enhance the Uppsala model. }\end{array}$ & $\begin{array}{l}\text { Conceptual } \\
\text { Article }\end{array}$ \\
\hline Root & $\begin{array}{l}\text { Jones, Coviello, \& } \\
\text { Tang (2011) }\end{array}$ & $\begin{array}{l}\text { Identify potential areas to develop } \\
\text { this theory. }\end{array}$ & $\begin{array}{l}\text { Conceptual } \\
\text { Article }\end{array}$ \\
\hline Root & $\begin{array}{l}\text { Oviatt \& McDougal } \\
\text { (1994) }\end{array}$ & $\begin{array}{l}\text { The elements that this type of } \\
\text { companies have: the } \\
\text { internationalisation of some } \\
\text { transactions, the dependence on } \\
\text { networks to obtain resources, the } \\
\text { establishment of advantages in the } \\
\text { external market, and the control } \\
\text { over strategic resources. } \\
\text { Additionally, they define the born } \\
\text { global companies. }\end{array}$ & $\begin{array}{l}\text { Conceptual } \\
\text { Article }\end{array}$ \\
\hline Root & Sarasvathy (2001) & $\begin{array}{l}\text { Discovers that the logic of } \\
\text { effectuation is used in situations } \\
\text { that are characterized by great risks } \\
\text { and uncertainty; while the logic of } \\
\text { causation is used when the future is } \\
\text { predictable. }\end{array}$ & $\begin{array}{l}\text { Conceptual } \\
\text { Article }\end{array}$ \\
\hline Root & $\begin{array}{l}\text { Schweizer, Vahlne, } \\
\text { \& Johanson (2010) }\end{array}$ & $\begin{array}{l}\text { The effectuation contributes } \\
\text { substantially to the explanation of } \\
\text { the internationalisation of SMEs. }\end{array}$ & $\begin{array}{l}\text { Conceptual } \\
\text { Article }\end{array}$ \\
\hline Root & Yin (2003) & $\begin{array}{l}\text { Explains the steps to develop an } \\
\text { investigation from case studies. }\end{array}$ & $\begin{array}{l}\text { Conceptual } \\
\text { Article }\end{array}$ \\
\hline Trunk & $\begin{array}{l}\text { Evers \& O 'gorman } \\
(2011)\end{array}$ & $\begin{array}{l}\text { The internationalisation of } \\
\text { companies is influenced by their } \\
\text { previous knowledge on } \\
\text { internationalisation and by the } \\
\text { networks they had. Throughout the } \\
\text { process, the authors observed the } \\
\text { logic of effectuation. }\end{array}$ & $\begin{array}{l}\text { Qualitative } \\
\text { Study }\end{array}$ \\
\hline Trunk & $\begin{array}{l}\text { Evers, Andersson, } \\
\text { \& Hannibal (2012) }\end{array}$ & $\begin{array}{l}\text { The logic of effectuation is crucial to } \\
\text { manage and leverage the networks } \\
\text { and thus improve the marketing } \\
\text { capabilities of born global } \\
\text { companies. }\end{array}$ & $\begin{array}{l}\text { Qualitative } \\
\text { Study }\end{array}$ \\
\hline Trunk & $\begin{array}{l}\text { Fuerst \& Zettinig } \\
(2015)\end{array}$ & $\begin{array}{l}\text { By implementing the logic of } \\
\text { effectuation, the networks become } \\
\text { a source of international knowledge. }\end{array}$ & $\begin{array}{l}\text { Qualitative } \\
\text { Study }\end{array}$ \\
\hline
\end{tabular}




\begin{tabular}{|c|c|c|c|}
\hline Trunk & $\begin{array}{l}\text { Gabrielsson \& } \\
\text { Gabrielsson (2013) }\end{array}$ & $\begin{array}{l}\text { The logic of effectuation increases } \\
\text { the possibility of identifying } \\
\text { opportunities. This, in turn, is } \\
\text { influenced by the networks and } \\
\text { capabilities of the company. }\end{array}$ & $\begin{array}{l}\text { Qualitative } \\
\text { Study }\end{array}$ \\
\hline Trunk & $\begin{array}{l}\text { Galkina \& Chetty } \\
(2015)\end{array}$ & $\begin{array}{l}\text { Entrepreneurs create their networks } \\
\text { following a logic of effectuation. }\end{array}$ & $\begin{array}{l}\text { Qualitative } \\
\text { Study }\end{array}$ \\
\hline Trunk & $\begin{array}{l}\text { Kalinic, Sarasvathy, } \\
\text { \& Forza (2014) }\end{array}$ & $\begin{array}{l}\text { Companies use the logic of } \\
\text { effectuation when the company } \\
\text { must overcome complex problems } \\
\text { for its internationalisation. In } \\
\text { contrast, they use causation when } \\
\text { they have information and } \\
\text { resources to internationalize. }\end{array}$ & $\begin{array}{l}\text { Qualitative } \\
\text { Study }\end{array}$ \\
\hline Trunk & Mort et al. (2012) & $\begin{array}{l}\text { The use of entrepreneurial } \\
\text { marketing, combined with the logic } \\
\text { of effectuation, generates superior } \\
\text { performance of companies in the } \\
\text { external market. }\end{array}$ & $\begin{array}{l}\text { Qualitative } \\
\text { Study }\end{array}$ \\
\hline Trunk & $\begin{array}{l}\text { Nowiński \& Rialp } \\
\text { (2013) }\end{array}$ & $\begin{array}{l}\text { Companies use the logic of } \\
\text { effectuation in order to overcome } \\
\text { resource constraints. }\end{array}$ & $\begin{array}{l}\text { Qualitative } \\
\text { Study }\end{array}$ \\
\hline Trunk & $\begin{array}{l}\text { Nummela, } \\
\text { Saarenketo, } \\
\text { Jokela, \& Loane } \\
\text { (2014) }\end{array}$ & $\begin{array}{l}\text { Once the companies have } \\
\text { accessed the international market, } \\
\text { the decision-making process } \\
\text { fluctuates between causation and } \\
\text { effectuation. }\end{array}$ & $\begin{array}{l}\text { Qualitative } \\
\text { Study }\end{array}$ \\
\hline Trunk & $\begin{array}{l}\text { Chetty, Ojala, \& } \\
\text { Leppäaho (2015) }\end{array}$ & $\begin{array}{l}\text { The companies alternate the logic } \\
\text { of effectuation and causation since } \\
\text { these are not contrary but } \\
\text { substitutes. }\end{array}$ & $\begin{array}{l}\text { Qualitative } \\
\text { Study }\end{array}$ \\
\hline Trunk & $\begin{array}{l}\text { Sarasvathy, Kumar, } \\
\text { York, \& } \\
\text { Bhagavatula (2014) }\end{array}$ & $\begin{array}{l}\text { Identifies potential areas of } \\
\text { research in which } \\
\text { internationalisation and effectuation } \\
\text { are related. }\end{array}$ & $\begin{array}{l}\text { Qualitative } \\
\text { Study }\end{array}$ \\
\hline Leaves & $\begin{array}{l}\text { Yang \& } \\
\text { Gabrielsson (2017) }\end{array}$ & $\begin{array}{l}\text { Companies that use the logic of } \\
\text { effectuation are more likely than } \\
\text { companies that use causation to } \\
\text { perform the following activities: } \\
\text { market creation, co-creation of } \\
\text { value, proactivity, innovation, risk } \\
\text { management, leveraging of } \\
\text { resources, and creation of } \\
\text { relationships with the client. }\end{array}$ & $\begin{array}{l}\text { Qualitative } \\
\text { Study }\end{array}$ \\
\hline
\end{tabular}




\begin{tabular}{|c|c|c|c|}
\hline Leaves & Ahi et al. (2017) & $\begin{array}{l}\text { Companies use the logic of } \\
\text { effectuation to initially enter the } \\
\text { international market. Then, this } \\
\text { logic changes for causation. }\end{array}$ & $\begin{array}{c}\text { Qualitative } \\
\text { Study }\end{array}$ \\
\hline Leaves & Chandra (2017) & $\begin{array}{l}\text { Proposes a model to broaden the } \\
\text { scope of effectuation by means of } \\
\text { three rules for evaluating } \\
\text { opportunities: simple, revised, and } \\
\text { complex. }\end{array}$ & $\begin{array}{c}\text { Qualitative } \\
\text { Study }\end{array}$ \\
\hline Leaves & $\begin{array}{l}\text { Chandra, Styles, \& } \\
\text { Wilkinson (2015) }\end{array}$ & $\begin{array}{l}\text { The logic of effectuation is evident } \\
\text { in the processes of discovery of } \\
\text { opportunities and product } \\
\text { propotyping. After this process, the } \\
\text { use of causation is more evident. }\end{array}$ & $\begin{array}{c}\text { Qualitative } \\
\text { Study }\end{array}$ \\
\hline Leaves & $\begin{array}{l}\text { Crick \& Crick } \\
(2016)\end{array}$ & $\begin{array}{l}\text { The manager's team affects the } \\
\text { decision-making of the company, } \\
\text { which develops between the logic of } \\
\text { effectuation and the causation. }\end{array}$ & $\begin{array}{c}\text { Qualitative } \\
\text { Study }\end{array}$ \\
\hline Leaves & $\begin{array}{l}\text { Deligianni, } \\
\text { Voudouris, \& } \\
\text { Lioukas (2017) }\end{array}$ & $\begin{array}{l}\text { The logic of effectuation has a } \\
\text { positive effect on the diversification } \\
\text { of products and the performance of } \\
\text { nascent companies. }\end{array}$ & $\begin{array}{c}\text { Quantitative } \\
\text { Study }\end{array}$ \\
\hline Leaves & $\begin{array}{l}\text { Kujala \& Törnroos } \\
(2018)\end{array}$ & $\begin{array}{l}\text { The effectuation and capabilities of } \\
\text { the company explain the } \\
\text { internationalisation of companies in } \\
\text { Ghana. }\end{array}$ & $\begin{array}{l}\text { Qualitative } \\
\text { Study }\end{array}$ \\
\hline Leaves & $\begin{array}{l}\text { Laine \& Galkina } \\
(2017)\end{array}$ & $\begin{array}{l}\text { Although companies use the logic } \\
\text { of effectuation and causation } \\
\text { simultaneously, when there is an } \\
\text { increase in institutional uncertainty, } \\
\text { the use of effectuation is } \\
\text { augmented. }\end{array}$ & $\begin{array}{l}\text { Qualitative } \\
\text { Study }\end{array}$ \\
\hline Leaves & Nemkova (2017) & $\begin{array}{l}\text { Effectuation and creativity explain } \\
\text { the agility with which companies are } \\
\text { internationalized. }\end{array}$ & $\begin{array}{c}\text { Qualitative } \\
\text { Study }\end{array}$ \\
\hline Leaves & $\begin{array}{l}\text { Ripollés \& Blesa } \\
(2017)\end{array}$ & $\begin{array}{l}\text { Using the logic of effectuation to } \\
\text { create networks has a positive } \\
\text { impact on the first stage of the } \\
\text { internationalisation of the company. }\end{array}$ & $\begin{array}{c}\text { Quantitative } \\
\text { Study }\end{array}$ \\
\hline
\end{tabular}

Source: Compiled by the authors based on Tree of Science. 


\subsection{Conclusion}

Based on bibliometric analysis, this article describes the development of research on the theory of effectuation and the internationalisation of SMEs. Using mathematical and statistical methods, the impact of author citations and citations of articles published in the most influential journals' (i.e. papers in other journals that cite papers that appear in influential journals) was evaluated, and connections were identified through co-citation analysis, bibliographic coupling and co-word analysis. This analysis shows the conceptual structure of this research field.

The articles that provide the foundation for this research area indicate that the conceptual and theoretical basis consists of the theory of effectuation (Sarasvathy, 2001), born globals and analysis of born globals using the theory of effectuation (Andersson, 2011; Harms and Schiele, 2012; Oviatt and McDougal, 1994), the Uppsala model and analysis of this model using the theory of effectuation (Johanson and Vahlne, 1977, 2009; Schweizer et al., 2010), international entrepreneurship (Jones et al., 2011), and theory creation based on case studies (Eisenhardt, 1989; Yin, 2003).

Research on the effectuation and internationalisation of SMEs is structured into five areas: 1) The decision-making process of entrepreneurs during the internationalisation of the company; 2) The development of international entrepreneurship based on the theory of effectuation; 3) The analysis of entrepreneurial marketing using the theory of effectuation; 4) The impact of effectuation logic on knowledge acquisition, international opportunity identification and network creation; and 5) The impact of effectuation logic on the growth and survival of SMEs in international markets.

The most recent articles show that the trend of research on the internationalisation of SMEs and the theory of effectuation is oriented towards furthering our knowledge of the five areas that lend structure to this area. Analysis of the most influential journals shows that research in this area is concentrated in just a few journals. The 
vast majority of studies use qualitative methodologies and examine SMEs from developed economies.

The main research implication of our study is that it maps the conceptual structure of this research field. The results of this study provide a better understanding of the intellectual structure of this area and can help scholars in this area focus their research and identify new avenues of research. The division of the literature into five areas helps managers understand the different dimensions that are important to the theory of effectuation and the internationalisation of SMEs. First, research on the decision-making processes of entrepreneurs should show managers how this process affects a firm's internationalisation process. Second, managers should be aware of the effects of combining effectuation, creativity and marketing on international market entry. Finally, managers should recognise the impact of effectuation logic on knowledge acquisition, opportunity identification, networking, and the growth and survival of SMEs in international markets.

\subsection{Limitations and research opportunities}

Although WoS and Scopus contains the most prestigious and high-impact journals, it does not cover all articles related to the theory of effectuation and the internationalisation of SMEs. Accordingly, studies in journals in other indices such as Google Scholar were not included in this article. Therefore, caution should be exercised when generalising these results. Nevertheless, this study covers the most relevant journals in relation to the theory of effectuation and the internationalisation of SMEs. Therefore, the articles covered in this study are representative of the strongest contributions to international business research. Future bibliometric analysis should include papers from other indices such as Google Scholar.

Another limitation is that the analysis of citations and co-citations fails to interpret the purpose with which authors cite another study. More specifically, it fails to consider the intention with which an author cites a given study. Additionally, this field of research is in a nascent stage, so future research should use quantitative studies to evaluate new propositions to continue developing this area. These quantitative 
studies could focus on developing some of the five research areas described in this article. Further research that uses SMEs in developing economies as a unit of analysis should also be performed. This approach is particularly relevant because institutional uncertainty, which is a characteristic of developing economies, tends to encourage the use of effectuation (Laine and Galkina, 2017). Finally, an interesting new avenue of research would be to study the impact of effectuation theory on the internationalisation of family businesses. Recent studies have shown that family firms have different decision-making processes (Kallmuenzer et al., 2018), which affect their internationalisation processes (Cesinger et al., 2014). 


\section{Chapter Three - When do domestic networks cause accelerated internationalisation under different decision-making logic? Evidence from contexts with institutional voids}

\subsection{Introduction}

Past research suggests that networks are particularly important for small and medium-sized firms (SMEs), as these firms typically face resource constraints needed for accelerated internationalisation (Coviello, 2015; Ellis, 2011; Freeman \& Cavusgil, 2007; Johanson \& Vahlne, 1977; Knight \& Cavusgil, 2004; Oviatt \& McDougal, 1994; Pinho \& Prange, 2016; Pla-Barber \& Escribá-Esteve, 2006). Likewise, others have studied the impact of the decision-making logic of the firm on the accelerated internationalisation of the firm (Gabrielsson \& Gabrielsson, 2013). However, despite the significant progress made, the following research gaps were identified. First, scholars still find that much work is still pending on identifying which causal conditions contribute to accelerated internationalisation (Casillas \& Acedo, 2013; Coviello, 2015; Madsen, 2013). Accelerated internationalisation, has been defined in terms of the length of time between inception and first international sales (speed); the number of foreign countries in which sales are generated (scope), and the percentage of foreign on total sales (extent) (Kuivalainen, Sundqvist, \& Servais, 2007; Madsen, 2013; Weerawardena et al., 2007; Zahra \& George, 2002). For the purpose of this article, we consider accelerated internationalisation when the firm became international within 3 years after their inception and were selling more than $25 \%$ to four or more foreign countries.

Among the causal conditions that might explain accelerated internationalisation, networks (strong or weak ties) and decision-making logic (effectuation or causation) seem to be the most promising (Andersson, 2011; Galkina \& Chetty, 2015; Kujala \& Törnroos, 2018; Sarasvathy et al., 2014; Schweizer, Vahlne, \& Johanson, 2010). However, the empirical literature on the relationship between networks, decisionmaking logic, and accelerated internationalisation produces mixed results. While some studies find that strong ties accelerate internationalisation (Gulati, Lavie, \& 
Madhavan, 2011; Söderqvist \& Chetty, 2013), others show that weak ties accelerate internationalisation (Galkina \& Chetty, 2015; Kontinen \& Ojala, 2011; Rindfleisch \& Moorman, 2001). According to Granovetter (1973), network relationships can be classified into strong or weak ties depending on the amount of time, emotional intensity, intimacy, and reciprocal communication among firms. Strong network ties are characterized by having a close relationship, trust, commitment, and deep knowledge of each other; while weak ties are characterized by having a superficial relationship and shallow knowledge of each other (Söderqvist \& Chetty, 2013).

Similarly, different results have been reached about the impact of the decisionmaking logic on the accelerated internationalisation (Jones, Coviello, \& Tang, 2011; Schweizer et al., 2010; Spence \& Crick, 2006). Some studies argue that causation logic enhances internationalisation (Brewer, 2001; Brouthers \& Nakos, 2005; Lukas, Whitwell, \& Hill, 2007), while many researchers state that effectuation decisionmaking logic speeds internationalisation (Andersson, 2011; Gabrielsson \& Gabrielsson, 2013; Nowiński \& Rialp, 2013; Vasilchenko \& Morrish, 2011). Alike, other studies suggested that the change of the decision-making logic from causation to effectuation accelerate the internationalisation process (Bell, Mcnaughton, \& Young, 2003; Kalinic, Sarasvathy, \& Forza, 2014). According to the decision-making logic approach, internationalisation can happen as a result of causation (planned and predictive) or effectuation (unplanned and non-predictive) of the firm (Kalinic et al., 2014). Causation occurs when the firm forecasts scenarios, estimates consequences, analyzes long run opportunities, and predicts and controls the future (Chandler et al., 2011). In contrast, effectuation occurs when the action of the firm includes experimentation, affordable loss, flexibility, pre-commitments, and the conception that the future can be created (Chandler et al., 2011).

Networks and decision-making logic as causal conditions that might explain the accelerated internationalisation has been explored relatively recently, with mixed results. The scarce research reveals that effectuation decision-making logic seems to enhance rapid internationalisation either with strong ties (Gabrielsson \& Gabrielsson, 2013), weak ties (Chandra, Styles, \& Wilkinson, 2009; Galkina \& 
Chetty, 2015), or both types of relationship (Zaefarian, Eng, \& Tasavori, 2016). Studies have also suggest that accelerated internationalisation is explained by strong ties and causation logic (Ellis, 2011), or by both, weak and strong ties and effectuation decision-making. Sarasvathy (2008) blames firm-level and contextual factors for the diversity of these results. The firm-level factor might be the differences on the firm's resource constraints, while the contextual factor could be the perception of uncertainty and risk, which tend to be more common in contexts with institutional voids.

The second gap in the literature pertains to the limited research on domestic networks (Milanov \& Fernhaber, 2014; Prashantham \& Birkinshaw, 2015; Xu, Lin, \& Lin, 2008). To a large extent, the literature on accelerated internationalisation focuses predominantly on foreign networks (Prashantham \& Birkinshaw, 2015). The few studies that focus on domestic networks evidence a lack of consensus about what type of domestic network relationship contributes the most (Bell, 1995; Boehe, 2013; Chandra et al., 2009; Kontinen \& Ojala, 2011; Manolova, Manev, \& Gyoshev, 2010; Milanov \& Fernhaber, 2014; Söderqvist \& Chetty, 2013; Xu et al., 2008).

A third gap relates to the scarce investigation of accelerated internationalisation on countries characterized by institutional voids (Boehe, 2013; Haddoud, Jones, \& Newbery, 2017; Knight \& Liesch, 2016). By institutional voids, we mean a context that is characterized by absence or underdevelopment of regulatory institutions and enforced structure of laws (Scott, 2014), which usually generates political instability and corruption (Hiatt \& Sine, 2014). This environment is likely to be problematic for the internationalisation of the firms, because it creates adds operation costs at home and reduces firm performance (North, 1990; Spencer \& Gomez, 2011; Tang, Tang, \& Katz, 2014). Particularly, the literature reveals that institutional voids lessen the international performance of Latin American SMEs (Cardoza, et al., 2016; Ciravegna, Lopez, \& Kundu, 2016; Torkkeli \& Fuerst, 2018). In the opposite way, SMEs may venture abroad as a means to reduce exposure to institutional voids at home (Cuervo-Cazurra, 2016; Cuervo-Cazurra, et al., 2018; Deng \& Zhang, 2018; Witt \& Lewin, 2007). Institutional voids can influence the causal conditions that lead 
to the accelerated internationalisation of a firm (Hiatt \& Sine, 2014; Paul, Parthasarathy, \& Gupta, 2017; Vasilchenko \& Morrish, 2011); consequently, the results might differ from developed to developing countries (North, 1990; Narooz \& Child, 2017). Indeed, such institutional weaknesses generate challenges for firms based in developing countries, which can be overcome by levering networks (Khanna \& Palepu, 2010). Moreover, prior research has suggested that the home country's institutional environment shapes firm decision-making logic (Khanna, Palepu, \& Sinha, 2005). Therefore, there is a need for a refined understanding on which type of domestic ties and decision-making logic contribute to accelerated internationalisation among SMEs located in contexts with institutional voids (Cavusgil \& Knight, 2015; Sarasvathy et al., 2014; Vanninen, Kuivalainen, \& Ciravegna, 2017).

Finally, accelerated internationalisation is a complex phenomenon that should be studied by identifying the complex relations among variables (Chetty, Johanson, \& Martín, 2014). However, most studies identify the causes using symmetric tests, such as the structural equation modelling (SEM) or the multiple regression analysis (MRA) (Casillas \& Acedo, 2013). It means that traditional methods treat configurations as separate types of cases and assume that the relationships between the dependent and independent variables are symmetric. Because complex phenomenon is usually conform by cases with asymmetric relationship, traditional linear regression models might not be suitable to explain it (Bell, Filatotchev, \& Aguilera, 2014; Rihoux \& Ragin, 2008; Woodside, 2013). Thus, a different approach is needed to capture these complexities and the combinations of factors that explain the accelerated internationalisation of SMEs. In consideration of this gap in the literature, we use the fuzzy-set qualitative comparative analysis (fsQCA), because this method is particularly appropriate when causality is complex (Woodside, 2014). Moreover, fsQCA accept asymmetric relationships between the dependent and the independent variable (Woodside, 2013). Lastly, the fsQCA can identify several equifinal combinations of dependent variables that are sufficient to produce the independent variable (Woodside, 2013). 
To our knowledge, no research has integrated the analysis of the domestic network with the decision-making logic in order to understand the causal conditions that lead to accelerated internationalisation. Thus, the following research question is framed: What configurations of domestic network and decision-making logic explain accelerated internationalisation of firms located in contexts with institutional voids?

The research question is addressed by performing the fsQCA analysis in order to analyse 33 cases of SMEs located in countries characterized by institutional voids. The dataset has several advantages. First, it has a country comparison design. This reduce the risk of obtaining results, which are overly specific to one particular country. Colombia and Peru were chosen because they have institutional voids (Levitsky \& Murillo, 2013); characterized by political instability and corruption (Mesquita \& Lazzarini, 2008; WEF, 2018). Second, our sample includes contrarian cases that support the necessity of modelling multiple realities using complex antecedent configurations (Woodside, 2014). The fsQCA is characterized through causal asymmetry and applicability to small samples, because causal conditions or their combinations frequently leading to an equifinal outcome are observed. Thanks to its potential to capture the high degree of complexity through theoretical based premises and contextual influences, this tool is increasingly applied in business and management research (Covin et al., 2016; Denk \& Lehtinen, 2014; Kraus et al., 2016; Rihoux et al., 2013; Schneider \& Wagemann, 2012). In this study, the outcome is accelerated internationalisation (Kuivalainen et al., 2007; Madsen, 2013; Weerawardena et al., 2007; Zahra \& George, 2002). The causal conditions are domestic network relationships (Söderqvist \& Chetty, 2013), and decision-making logic (Sarasvathy, 2001). As control conditions, we also include the existence of external or internal barriers to export (Uner et al., 2013) if the firm has been benefited from any export promotion program; and the size of the firm, measured by the number of employees (Kalantaridis \& Vassilev, 2011). This last variable was used to measure the difference of the firm's resource constraints. In the sample: 24 percent of the firms are micro (with less than 10 employees) and 76 percent are small firms (between 11 and 50 employees). 
Our results suggest that the combination of weak domestic ties and effectuation decision-making logic accelerates internationalisation of SMEs with fewer resource constraints in contexts with institutional voids. In contrast, strong domestic ties and causation behaviour lead to accelerated internationalisation of SMEs with greater resource constraints under institutional voids context. Our contribution to the literature is threefold. First, we provide empirical explanations related to the combination of the type of domestic networks and decision-making logic, and its impact on the accelerated internationalisation of SMEs located in contexts with institutional voids, such as Latin America. We suggest that effectuation and causation logic change according to the circumstances and the environment of the firm. Second, we contribute to the internationalisation literature by expanding the literature on domestic networks. Third, we contribute to the scarce investigation in countries characterized by institutional voids. Based on these results, we developed an integrative model that linked the causal configurations to reach accelerated internationalisation.

\subsection{Theoretical framework}

\subsubsection{Accelerated internationalisation of SMEs}

Networks and decision-making logic are becoming the dominant paradigm that explains the accelerated internationalisation of SMEs (Andersson, 2011; Galkina \& Chetty, 2015; Kujala \& Törnroos, 2018; Sarasvathy et al., 2014; Schweizer et al., 2010). Nevertheless, the term accelerated internationalisation have been ascribed numerous definitions (Casillas \& Acedo, 2013; Chetty et al., 2014; Kuivalainen, Saarenketo, \& Puumalainen, 2012). A common definition consist in understanding and measuring accelerated internationalisation in terms of the length of time between the inception and the first international sales (speed); the number of foreign countries in which sales are generated (scope), and the percentage of foreign on total sales (extent) (Kuivalainen et al., 2007; Madsen, 2013; Weerawardena et al., 2007; Zahra \& George, 2002). 
It is of particular interest to the international entrepreneurship scholars the reason why some firms and not others, achieve accelerated internationalisation (Mathews \& Zander, 2007; Pla-Barber \& Escribá-Esteve, 2006; Ripolles \& Blesa, 2012). Among the theoretical frameworks, the Born Global approach has made great contributions to answer this question (Knight \& Liesch, 2016). This approach argues that Born Global firms are typically young SMEs that despite their limited resources are able to internationalize at or soon after inception (Cavusgil \& Knight, 2009; Knight \& Cavusgil, 2004; Weerawardena et al., 2007). It happens because Born Globals possess unique firm-specific resources, network relationships, and international entrepreneurship orientation (Cavusgil \& Knight, 2009; Chetty \& Blankenburg Holm, 2000; Coviello \& Cox, 2006; Rialp, Rialp, \& Knight, 2005; Sharma \& Blomstermo, 2003; Zhou, Wu, \& Luo, 2007).

Among these characteristics, the strength of the network ties are the key element that help SMEs to overcome the lack of resources to internationalize (BelsoMartínez, 2006; Chetty \& Blankenburg Holm, 2000; Coviello \& Cox, 2006; Sharma \& Blomstermo, 2003; Zhou et al., 2007). Scholars argue that strong ties accelerate internationalisation through knowledge sharing and resource exchanging (Gulati et al., 2011; Söderqvist \& Chetty, 2013). Close interactions among partners foster the emergence of common norms and trust that reduce risk and opportunism; however, repeated interaction with close partners progressively leads to redundancy, and reduces information novelty (Hayton, Chandler, \& DeTienne, 2011). The resulting atmosphere of common confidence creates strong ties that are extremely relevant for the acceleration of the internationalisation, which seems crucial in contexts of low-level institutional development, such as Colombia and Peru (Fuerst \& Zettinig, 2015; Kiss \& Danis, 2008). In this context, strong ties lessen the risk (Brache \& Felzensztein, 2019), while weak ties are hard to support due to insufficient institutional infrastructure (Kiss, Danis, \& Cavusgil, 2012).

In relation to weak ties, firms use this networks to share novel information, help to identify different opportunities, and therefore, reduce uncertainty and accelerate internationalisation (Galkina \& Chetty, 2015; Kontinen \& Ojala, 2011; Rindfleisch \& 
Moorman, 2001). Particularly, access to non-redundant information opens avenues for alternative strategies and decision-making that spur internationalisation (Granovetter, 1973). Robust institutional frameworks characterizing developed economies, moderate the need for close monitoring and boost the influence of weak ties in the internationalisation speed (Kiss \& Danis, 2008). Both strong and weak ties help to acquire internationalisation knowledge and thus, to internationalize rapidly (Chandra et al., 2009). However, their relative contribution is shaped by the specificities in the context of a firm (Lages \& Montgomery, 2004), specifically in developing economies. Institutional voids environment create insufficient incentives for firms to develop resources and capabilities (Boehe et al., 2016). Therefore, firms need to rely on their network relations to overcome their resource constraints (Bruton et al., 2008; Lingelbach et al., 2015).

\subsubsection{Accelerated Internationalisation: Foreign vs. Domestic Networks}

Research on networks and accelerated internationalisation has mostly focused on foreign networks (Prashantham \& Birkinshaw, 2015). To a great extent, findings suggest that internationalisation is accelerated by vicarious internationalisation knowledge provided by foreign networks (Dimitratos et al., 2014; Fernhaber \& Li, 2010; Knight \& Cavusgil, 2004; Oviatt \& McDougal, 1994; Schwens \& Kabst, 2009). Knowledge that is accessed through foreign partners may help firms to accelerate their internationalisation by reducing uncertainties about external markets (Ellis \& Pecotich, 2001), giving familiarity with the host country (Johanson \& Vahlne, 2009; Schwens \& Kabst, 2011; Sommer \& Haug, 2011), or gaining experience from foreign network partners (Chetty \& Blankenburg Holm, 2000; Fernhaber \& Li, 2013; Fernhaber, McDougal, \& Shepherd, 2009; Loane \& Bell, 2006).

From a different perspective, foreign networks allow firms to identify business opportunities (Chetty \& Agndal, 2007; Ellis, 2000; Harris \& Wheeler, 2005), and enhance the perception of feasibility and desirability of foreign opportunities (Nowinski \& Rialp, 2016). Empirical evidences support the positive effect of non- 
domestic relationships on the progressive involvement in international operations (Cavusgil \& Knight, 2009; Knight, Madsen, \& Servais, 2004; Mort \& Weerawardena, 2006).

Although less explored, firms may also take advantage of their domestic networks to develop international relationships (Montoro-Sanchez, Diez-Vial, \& BelsoMartínez, 2018), to accumulate internationalisation knowledge (Milanov \& Fernhaber, 2014; Ryan, Evers, Smith, \& Andersson, 2019), to promote and brand its products (Felzensztein, Deans, \& Dana, 2017), to develop networking skills (Leppäaho, Chetty, \& Dimitratos, 2018), or to increase their export intensity (Boehe, 2013). In this vein, Bell (1995) found that SMEs accelerate their internationalisation process by following their existing domestic networks abroad. From another perspective, sharing knowledge about international markets and operations with the domestic counterparts, either at the inter-organizational (Xu et al., 2008) or the interpersonal level (Manolova et al., 2010) also fosters foreign sales. In fact, domestic networks have a positive impact on the speed, scope, and extent of the internationalisation of the firm (Fernhaber, Gilbert, \& McDougal, 2008; Prashantham \& Young, 2011). Despite of this prevalent benign effect, engagement in domestic networks may become harmful since too much domestic embeddedness can lead to the relegation of international business opportunities and slow down the whole internationalisation process (Prashantham \& Birkinshaw, 2015; Prashantham \& Dhanaraj, 2010).

\subsubsection{Decision-making logic causing accelerated internationalisation: domestic networks and effectuation}

Previous research explain that Born Globals accelerated their internationalisation process either as a rationally decision-making logic driven by key actors or as an unplanned decision-making logic that is co-created within their networks (Andersson, 2011). The difference among the decision-making logic lies on the way the firm perceives the future, manages its capabilities and resources, and addresses 
uncertainty and risk (Sarasvathy, 2001). The rationally decision-making logic is called causation and is characterized by having a clear goal and a plan on how to manage the capabilities and resources to achieve it. Therefore, it includes forecasting scenarios, estimating consequences, analyzing long run opportunities, predicting and controlling the future, and reducing risk (Chandler et al., 2011; Chetty, Ojala, \& Leppäaho, 2015). In contrast, the unplanned decision-making logic is called effectuation and consists on knowing the capabilities and resources at their disposal and on the creation or discovery of the goal. Therefore, it includes experimentation, affordable loss, flexibility, pre-commitments, the conception that the future can be created, and the reduction of uncertainty to create opportunities (Chandler et al., 2011; Chetty et al., 2015).

Recently, Born Global researchers turned to effectuation decision-making logic to have a deeper understanding about the internationalisation process of this type of firms (Andersson, 2011; Harms \& Schiele, 2012). Some authors have found that early phases of internationalisation are characterized by effectuation (Nowiński \& Rialp, 2013; Rialp-Criado, Galván-Sánchez, \& Suárez-Ortega, 2010; Spence \& Crick, 2006), while later phases are characterized by causation (Ahi et al., 2017; Gabrielsson \& Gabrielsson, 2013). However, in opposite direction, other authors have found that firms tend to apply mostly effectuation logic (Evers \& O'gorman, 2011; Harms \& Schiele, 2012; Sarasvathy et al., 2014).

A possible explanation for the mixed results may be defined by the context of the firm. Considering the influence of uncertainty, risk, resource constraints and networks, Sarasvathy et al. (2014) highlight that the approaches of causation and effectuation may help to better understand how fast a firm internationalizes. It seems that under conditions of uncertainty, effectual decision-making logic is preferred (Laine \& Galkina, 2017). The pre-commitments involved in the effectual thinking, define what firms will do with their partners. Hence, firms are able to control the future and cope with uncertainty (Wiltbank \& Sarasvathy, 2010). Moreover, firms uses their existing resources to experiment and identify international opportunities (Sarasvathy, 2001). In this way, firms may achieve the possible best outcomes with 
the resources at their disposal, and thus accelerated their internationalisation process. Nevertheless, firms with greater resource constraints might use causation logic for the following reasons. First, causation help firms to manage their scarce resources effectively and efficiently (Cao et al., 2009). Likewise, by predicting the future and setting goals and plans, firms are able to earn potential investments (Nummela et al., 2014). Finally, due to high resource constraints, firms do not assume international risk unless they see tangible benefits (Martín-Tapia et al., 2010). Therefore, causation as a mean to reduce risk is the most suitable decision (Sarasvathy, 2001).

Despite their complementarities, the integration of effectuation and internationalisation is still in its infancy, lacks unequivocal evidences, and needs further advances (Andersson, 2011; Arend, Sarooghi, \& Burkemper, 2015; Gabrielsson \& Gabrielsson, 2013; Read et al., 2016). This is especially true with regard to the combined effect of effectuation and the type of network ties on the acceleration of internationalisation. The scarce research focused on foreign networks reveals that rapid internationalisation may be the result of the combination of effectuation logic and weak ties (Chandra et al., 2009; Galkina \& Chetty, 2015), or both weak and strong ties (Zaefarian et al., 2016), and causation logic (Ellis, 2011). Sarasvathy (2008) blames firm-level and contextual factors for the diversity of these results.

In this vein, we can expect that the institutional voids strongly affect the networking and the decision-making logic of the firm (Cuervo-Cazurra \& Dau, 2009; Kujala \& Törnroos, 2018; Nowiński \& Rialp, 2013). This rationale possibly underlies recent claims on the need to extend the present comprehensions and evidences of how firms apply the effectuation logic in the context of institutional voids (Kiss et al., 2012). Indeed, in countries characterized by institutional voids, firms are aware of the potential negative impact that derives from the high levels of institutional uncertainty and risk. For instance, opportunism may harm the speed and results of the internationalisation strategy. In a planned and predictive logic characterizing causation logic, we may expect that firms with greater resource constraints will be 
more likely to rely on strong ties in order to reduce the risk and to manage their scarce resources effectively. So firms tend to prefer close trustful relationships to foster the internationalisation process. Thus, we developed the following proposition:

a) Proposition 1: Strong domestic ties combined with causation logic accelerate the internationalisation of firms with greater resource constraints that are located in contexts with institutional voids.

Conversely, firms that rely more on means (effectuation) rather than planned objectives (causation) are more open to new possibilities (Sarasvathy et al., 2014). This logic might lead the firms prefer weak domestic ties over strong domestic ties, because the former share new information, while the later exchange redundant information. It seems that the firms also use their existing resources to experiment and identify international opportunities. Finally, firms may create pre-commitments with their weak domestic ties in order to reduce uncertainty. Hence, we might expect that effectual firms would prefer weak domestic ties to get access to novel information and spur its internationalisation process. Thus, the following proposition is suggested:

b) Proposition 2: Weak domestic ties combined with effectuation logic accelerate the internationalisation of firms with fewer resource constraints that are located in contexts with institutional voids.

\subsection{Methodology}

\subsubsection{Analysis technique}

Accelerated internationalisation is a complex phenomenon (Chetty et al., 2014). Therefore, the traditional qualitative analysis might not be suitable to explain it (Bell et al., 2014; Rihoux \& Ragin, 2009; Woodside, 2013). Instead, the fuzzy-set qualitative comparative analysis ( $f s Q C A$ ) is a different approach that considers multilevel explanations and different causal paths that are satisfactory for certain outcome to occur (Ragin, 2008; Woodside, 2013). This basis allows for systematic cross-case comparisons and embraces within case complexity (Ragin, 2008). The 
fsQCA is a powerful analytical tool that is currently receiving considerable attention from different International Business scholars (Kraus et al., 2016). This article presents an application of fsQCA to explore whether causal configurations (i.e., domestic strong or weak ties) are sufficient for a certain outcome to occur (i.e., accelerated internationalisation).

\subsubsection{Sample}

In order to validate the use of fsQCA over typical quantitative methods for the analysis of data, contrarian cases were included. This analysis corroborates if a substantial number of cases display relationships that are contrary to the main effect (Woodside, 2014). If so, an asymmetrical relationship is revealed, which calls for fsQCA. Table 8 shows the contrarian cases and the main features of firm samples in this study.

The criteria for selecting the cases were firms that were connected to domestic networks, with less than 50 employees, with international operations, and willing to participate in the research. In the first stage, 42 exporting SMEs were accepted. However, after running the interviews, nine companies were rejected from the sample either because the person who had the first-hand export experience was not employed anymore at the firm or because the domestic network criteria was not clearly fulfilled. Hence, 33 cases were finally selected (21 from Colombia and 12 from Peru).

Prior research has suggested that the home country's institutional environment shapes the international performance of the firm (Krammer, Strange, \& Lashitew, 2018). Particularly, the internationalisation path is influenced by institutional voids that are characterized by political instability and corruption (Hiatt \& Sine, 2014). Moreover, there have been calls for investigating more case studies located in institutional voids, with special attention to Latin American countries (Boehe, 2013; Felzensztein et al., 2015; Felzensztein, 2016; Haddoud et al., 2017; Paul et al., 2017; Welch et al., 2011). Colombia and Peru are considered an interesting location for this study because these countries are characterized for having political instability 
and corruption. For instance, according to the Global Competitiveness Index, Colombia and Peru are among the countries with lowest institutional environment (ranked 126 and 123 respectively), due to the low public trust in politicians (ranked 124 and 126 respectively), efficiency of legal framework in settling disputes (ranked 122 and 129 respectively), organized crime (ranked 131 and 129 respectively), and business costs of crime and violence (ranked 128 and 122 respectively) (WEF, 2018). The report also highlights that the main problems for doing business in Colombia and Peru are corruption and inefficient government bureaucracy (WEF, 2018). In spite of the fact that $98 \%$ of Colombian and Peruvian companies are SMEs, only $4 \%$ are exporting (Urmeneta, 2016). Consequently, SMEs remain underrepresented in the Latin American export sector (Gordon \& Suominen, 2014). All these factors position Colombia and Peru as a suitable case to analyze.

In line with recent studies that have examined the relationship between networks and internationalisation, the data was gathered using a case study methodology through face-to-face qualitative interviewing (Chen, 2003; Chetty \& Agndal, 2007; Harris \& Wheeler, 2005; Hughes et al., 2017; Kontinen \& Ojala, 2011). Due to the fact that in small enterprises the decision-making process is usually made by one person (Chetty \& Campbell-Hunt, 2004; Söderqvist \& Chetty, 2013), in every case, the founder or Chief Executive Officer (CEO), or equivalent was interviewed. The interview began with general and main questions about the internationalisation process of the firm with open-ended questions (Wright, 2015). For the specific questions about the type of relationships (strong or weak), the study adapts constructs from Granovetter (1973), and Söderqvist and Chetty (2013), along with 5-point Likert response scales. Similar, to measure the decision-making logic into effectuation or causation, we adopt constructs from Chandler et al. (2011). The constructs are also measured on five-point Likert scale. Each interview was carried out individually, and digitally recorded and transcribed. Finally, we used secondary information, such as the company's web pages and official records about the firms.

Table 8. Contrarian cases and main features of firm samples in this study 


\begin{tabular}{|c|c|c|c|c|c|c|c|c|}
\hline $\begin{array}{l}\text { Size of the } \\
\text { firm }\end{array}$ & $\begin{array}{c}\text { Industry/busine } \\
\text { ss }\end{array}$ & $\begin{array}{l}\text { Countr } \\
\text { y of } \\
\text { origin }\end{array}$ & $\begin{array}{c}\text { Type of } \\
\text { domesti } \\
\text { C } \\
\text { network }\end{array}$ & $\begin{array}{l}\text { Decision- } \\
\text { making } \\
\text { process }\end{array}$ & $\begin{array}{c}\text { Number } \\
\text { of } \\
\text { employee } \\
s\end{array}$ & $\begin{array}{l}\text { Founding year/ } \\
\text { internationalisati } \\
\text { on year }\end{array}$ & $\begin{array}{l}\text { Exporting } \\
\text { countries }\end{array}$ & 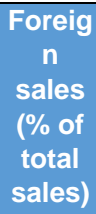 \\
\hline $\begin{array}{l}\text { Microenterpri } \\
\text { se } 1\end{array}$ & $\begin{array}{l}\text { Agro industrial / } \\
\text { Fruit Pulps }\end{array}$ & $\begin{array}{c}\text { Colombi } \\
\text { a }\end{array}$ & $\begin{array}{l}\text { Strong } \\
\text { domesti } \\
\text { c ties }\end{array}$ & $\begin{array}{l}\text { Causation } \\
\text { logic }\end{array}$ & 10 & 2016 / 2016 & Mexico & $50 \%$ \\
\hline $\begin{array}{l}\text { Microenterpri } \\
\quad \text { se } 2\end{array}$ & $\begin{array}{l}\text { Service / } \\
\text { Consulting }\end{array}$ & $\begin{array}{c}\text { Colombi } \\
\text { a }\end{array}$ & $\begin{array}{l}\text { Weak } \\
\text { domesti } \\
\text { c ties }\end{array}$ & $\begin{array}{l}\text { Effectuati } \\
\text { on logic }\end{array}$ & 9 & $2011 / 2014$ & $\begin{array}{c}\text { New } \\
\text { Zealand, } \\
\text { United } \\
\text { States, } \\
\text { and } \\
\text { Australia }\end{array}$ & $10 \%$ \\
\hline $\begin{array}{l}\text { Microenterpri } \\
\text { se } 3\end{array}$ & $\begin{array}{l}\text { Service / } \\
\text { Software }\end{array}$ & $\begin{array}{c}\text { Colombi } \\
\mathrm{a}\end{array}$ & $\begin{array}{c}\text { Weak } \\
\text { domesti } \\
\text { c ties }\end{array}$ & $\begin{array}{l}\text { Causation } \\
\text { logic }\end{array}$ & 7 & 2005 / 2015 & $\begin{array}{c}\text { Chile and } \\
\text { Peru }\end{array}$ & $20 \%$ \\
\hline $\begin{array}{l}\text { Microenterpri } \\
\text { se } 4\end{array}$ & $\begin{array}{l}\text { Manufacture/ } \\
\text { Metalworking }\end{array}$ & $\begin{array}{c}\text { Colombi } \\
\mathrm{a}\end{array}$ & $\begin{array}{c}\text { Weak } \\
\text { domesti } \\
\text { c ties }\end{array}$ & $\begin{array}{l}\text { Effectuati } \\
\text { on logic }\end{array}$ & 8 & 1992 / 2001 & Chile & $15 \%$ \\
\hline $\begin{array}{l}\text { Microenterpri } \\
\quad \text { se } 5\end{array}$ & $\begin{array}{l}\text { Manufacture / } \\
\text { Textiles \& } \\
\text { Apparel }\end{array}$ & $\begin{array}{c}\text { Colombi } \\
\mathrm{a}\end{array}$ & $\begin{array}{l}\text { Weak } \\
\text { domesti } \\
\text { c ties }\end{array}$ & $\begin{array}{l}\text { Causation } \\
\text { logic }\end{array}$ & 1 & 2002 / 2009 & $\begin{array}{l}\text { Germany, } \\
\text { United } \\
\text { States, } \\
\text { and } \\
\text { Mexico }\end{array}$ & $30 \%$ \\
\hline $\begin{array}{l}\text { Microenterpri } \\
\text { se } 6\end{array}$ & $\begin{array}{l}\text { Manufacture / } \\
\text { Textiles \& } \\
\text { Apparel }\end{array}$ & Peru & $\begin{array}{l}\text { Weak } \\
\text { domesti } \\
\text { c ties }\end{array}$ & $\begin{array}{l}\text { Causation } \\
\text { logic }\end{array}$ & 4 & 2008 / 2009 & $\begin{array}{c}\text { United } \\
\text { States, } \\
\text { Canada, } \\
\text { England, } \\
\text { Germany, } \\
\text { Switzerlan } \\
\text { d, Hungry, } \\
\text { Finland, } \\
\text { Australia }\end{array}$ & $100 \%$ \\
\hline $\begin{array}{l}\text { Microenterpri } \\
\text { se } 7\end{array}$ & $\begin{array}{l}\text { Agro industrial / } \\
\text { Fruit Pulps }\end{array}$ & Peru & $\begin{array}{l}\text { Strong } \\
\text { domesti } \\
\text { c ties }\end{array}$ & $\begin{array}{l}\text { Causation } \\
\text { logic }\end{array}$ & 7 & 2009 / 2010 & $\begin{array}{l}\text { Colombia, } \\
\text { Ecuador }\end{array}$ & $100 \%$ \\
\hline $\begin{array}{l}\text { Microenterpri } \\
\text { se } 8\end{array}$ & $\begin{array}{l}\text { Manufacture / } \\
\text { Textiles \& } \\
\text { Apparel }\end{array}$ & Peru & $\begin{array}{l}\text { Strong } \\
\text { domesti } \\
\text { c ties }\end{array}$ & $\begin{array}{l}\text { Causation } \\
\text { logic }\end{array}$ & 4 & 2017 / 2018 & Chile & $20 \%$ \\
\hline $\begin{array}{c}\text { Small } \\
\text { enterprise } 1\end{array}$ & $\begin{array}{l}\text { Manufacture / } \\
\text { Textiles \& } \\
\text { Apparel }\end{array}$ & $\begin{array}{c}\text { Colombi } \\
\mathrm{a}\end{array}$ & $\begin{array}{c}\text { Weak } \\
\text { domesti } \\
\text { c ties }\end{array}$ & $\begin{array}{l}\text { Effectuati } \\
\text { on logic }\end{array}$ & 16 & 1999 / 2010 & $\begin{array}{l}\text { Ecuador, } \\
\text { Panama, } \\
\text { and Peru }\end{array}$ & $25 \%$ \\
\hline $\begin{array}{c}\text { Small } \\
\text { enterprise } 2\end{array}$ & $\begin{array}{l}\text { Service / } \\
\text { Software }\end{array}$ & $\begin{array}{c}\text { Colombi } \\
\text { a }\end{array}$ & $\begin{array}{l}\text { Strong } \\
\text { domesti } \\
\text { c ties }\end{array}$ & $\begin{array}{l}\text { Causation } \\
\text { logic }\end{array}$ & 16 & 1999 / 2010 & $\begin{array}{l}\text { Ecuador } \\
\text { and } \\
\text { Panama }\end{array}$ & $25 \%$ \\
\hline $\begin{array}{c}\text { Small } \\
\text { enterprise } 3\end{array}$ & $\begin{array}{l}\text { Manufacture / } \\
\text { Textiles \& } \\
\text { Apparel }\end{array}$ & $\begin{array}{c}\text { Colombi } \\
\text { a }\end{array}$ & $\begin{array}{l}\text { Weak } \\
\text { domesti } \\
\text { c ties }\end{array}$ & $\begin{array}{l}\text { Effectuati } \\
\text { on logic }\end{array}$ & 16 & 1999 / 2008 & $\begin{array}{l}\text { Ecuador, } \\
\text { Costa } \\
\text { Rica, } \\
\text { Panama, } \\
\text { and Peru }\end{array}$ & $10 \%$ \\
\hline
\end{tabular}




\begin{tabular}{|c|c|c|c|c|c|c|c|c|}
\hline $\begin{array}{c}\text { Small } \\
\text { enterprise } 4\end{array}$ & $\begin{array}{l}\text { Manufacture/ } \\
\text { Metalworking }\end{array}$ & $\begin{array}{c}\text { Colombi } \\
\mathrm{a}\end{array}$ & $\begin{array}{c}\text { Weak } \\
\text { domesti } \\
\text { c ties }\end{array}$ & $\begin{array}{c}\text { Effectuati } \\
\text { on logic }\end{array}$ & 21 & 2007 / 2014 & Brazil & $30 \%$ \\
\hline $\begin{array}{c}\text { Small } \\
\text { enterprise } 5\end{array}$ & $\begin{array}{l}\text { Manufacture / } \\
\text { Furniture }\end{array}$ & $\begin{array}{c}\text { Colombi } \\
\text { a }\end{array}$ & $\begin{array}{l}\text { Weak } \\
\text { domesti } \\
\text { c ties }\end{array}$ & $\begin{array}{c}\text { Effectuati } \\
\text { on logic }\end{array}$ & 22 & 1994 / 2015 & $\begin{array}{l}\text { Ecuador } \\
\text { and Peru }\end{array}$ & $15 \%$ \\
\hline $\begin{array}{c}\text { Small } \\
\text { enterprise } 6\end{array}$ & $\begin{array}{c}\text { Manufacture / } \\
\text { Paints }\end{array}$ & $\begin{array}{c}\text { Colombi } \\
\text { a }\end{array}$ & $\begin{array}{c}\text { Weak } \\
\text { domesti } \\
\text { c ties }\end{array}$ & $\begin{array}{l}\text { Effectuati } \\
\text { on logic }\end{array}$ & 50 & 2013 / 2014 & $\begin{array}{c}\text { Costa } \\
\text { Rica, } \\
\text { Guatemal } \\
\text { a, and } \\
\text { Mexico }\end{array}$ & $20 \%$ \\
\hline $\begin{array}{c}\text { Small } \\
\text { enterprise } 7\end{array}$ & $\begin{array}{c}\text { Service } \\
\text { /Communication } \\
\text { Engineering }\end{array}$ & $\begin{array}{c}\text { Colombi } \\
\mathrm{a}\end{array}$ & $\begin{array}{l}\text { Weak } \\
\text { domesti } \\
\text { c ties }\end{array}$ & $\begin{array}{l}\text { Effectuati } \\
\text { on logic }\end{array}$ & 35 & $2001 / 2012$ & Peru & $15 \%$ \\
\hline $\begin{array}{c}\text { Small } \\
\text { enterprise } 8\end{array}$ & $\begin{array}{l}\text { Manufacture / } \\
\text { Textiles \& } \\
\text { Apparel }\end{array}$ & $\begin{array}{c}\text { Colombi } \\
\text { a }\end{array}$ & $\begin{array}{l}\text { Weak } \\
\text { domesti } \\
\text { c ties }\end{array}$ & $\begin{array}{c}\text { Effectuati } \\
\text { on logic }\end{array}$ & 11 & 2000 / 2011 & $\begin{array}{c}\text { Arab } \\
\text { Emirates, } \\
\text { Mexico, } \\
\text { and } \\
\text { Sweden }\end{array}$ & $10 \%$ \\
\hline $\begin{array}{c}\text { Small } \\
\text { enterprise } 9\end{array}$ & $\begin{array}{l}\text { Manufacture/ } \\
\text { Metalworking }\end{array}$ & $\begin{array}{c}\text { Colombi } \\
\text { a }\end{array}$ & $\begin{array}{l}\text { Strong } \\
\text { domesti } \\
\text { c ties }\end{array}$ & $\begin{array}{l}\text { Effectuati } \\
\text { on logic }\end{array}$ & 50 & 1964 / 1995 & Panama & $20 \%$ \\
\hline $\begin{array}{c}\text { Small } \\
\text { enterprise } 10\end{array}$ & $\begin{array}{c}\text { Service } \\
\text { /Electronic } \\
\text { Engineering }\end{array}$ & $\begin{array}{c}\text { Colombi } \\
\text { a }\end{array}$ & $\begin{array}{c}\text { Weak } \\
\text { domesti } \\
\text { c ties }\end{array}$ & $\begin{array}{l}\text { Effectuati } \\
\text { on logic }\end{array}$ & 13 & 2005 / 2014 & $\begin{array}{l}\text { United } \\
\text { States }\end{array}$ & $30 \%$ \\
\hline $\begin{array}{c}\text { Small } \\
\text { enterprise } 11\end{array}$ & $\begin{array}{l}\text { Service / } \\
\text { Software }\end{array}$ & $\begin{array}{c}\text { Colombi } \\
\text { a }\end{array}$ & $\begin{array}{l}\text { Weak } \\
\text { domesti } \\
\text { c ties }\end{array}$ & $\begin{array}{l}\text { Effectuati } \\
\text { on logic }\end{array}$ & 40 & 1998 / 1998 & $\begin{array}{l}\text { Canada, } \\
\text { Costa } \\
\text { Rica, } \\
\text { Ecuador, } \\
\text { United } \\
\text { States, } \\
\text { Guatemal } \\
\text { a, Mexico, } \\
\text { Peru, and } \\
\text { Venezuela }\end{array}$ & $65 \%$ \\
\hline $\begin{array}{c}\text { Small } \\
\text { enterprise } 12\end{array}$ & $\begin{array}{l}\text { Manufacture/ } \\
\text { Metalworking }\end{array}$ & $\begin{array}{c}\text { Colombi } \\
\text { a }\end{array}$ & $\begin{array}{c}\text { Weak } \\
\text { domesti } \\
\text { c ties }\end{array}$ & $\begin{array}{c}\text { Effectuati } \\
\text { on logic }\end{array}$ & 15 & 1999 / 2002 & $\begin{array}{c}\text { Bolivia, } \\
\text { United } \\
\text { States, } \\
\text { Guatemal } \\
\text { a, } \\
\text { Honduras, } \\
\text { Japan, } \\
\text { and } \\
\text { Mexico }\end{array}$ & $50 \%$ \\
\hline $\begin{array}{c}\text { Small } \\
\text { enterprise } 13\end{array}$ & $\begin{array}{l}\text { Service / } \\
\text { Software }\end{array}$ & Peru & $\begin{array}{l}\text { Strong } \\
\text { domesti } \\
\text { c ties }\end{array}$ & $\begin{array}{l}\text { Causation } \\
\text { logic }\end{array}$ & 32 & 2014 / 2016 & Panama & $3 \%$ \\
\hline $\begin{array}{c}\text { Small } \\
\text { enterprise } 14\end{array}$ & $\begin{array}{l}\text { Service / } \\
\text { Software }\end{array}$ & $\begin{array}{c}\text { Colombi } \\
\text { a }\end{array}$ & $\begin{array}{c}\text { Weak } \\
\text { domesti } \\
\text { c ties }\end{array}$ & $\begin{array}{c}\text { Effectuati } \\
\text { on logic }\end{array}$ & 24 & 2008 / 2011 & $\begin{array}{c}\text { Ecuador, } \\
\text { Guatemal } \\
\text { a, } \\
\text { Panama, } \\
\text { and Peru }\end{array}$ & $35 \%$ \\
\hline
\end{tabular}




\begin{tabular}{|c|c|c|c|c|c|c|c|c|}
\hline $\begin{array}{c}\text { Small } \\
\text { enterprise } 15\end{array}$ & $\begin{array}{l}\text { Agro industrial / } \\
\text { Fruit Pulps }\end{array}$ & Peru & $\begin{array}{c}\text { Weak } \\
\text { domesti } \\
\text { c ties }\end{array}$ & $\begin{array}{c}\text { Effectuati } \\
\text { on logic }\end{array}$ & 50 & 2013 / 2015 & France & $10 \%$ \\
\hline $\begin{array}{c}\text { Small } \\
\text { enterprise } 16\end{array}$ & $\begin{array}{l}\text { Manufacture / } \\
\text { Book Printing }\end{array}$ & $\begin{array}{c}\text { Colombi } \\
\mathrm{a}\end{array}$ & $\begin{array}{c}\text { Strong } \\
\text { domesti } \\
\text { c ties }\end{array}$ & $\begin{array}{l}\text { Causation } \\
\text { logic }\end{array}$ & 14 & 2000 / 2009 & Peru & $10 \%$ \\
\hline $\begin{array}{c}\text { Small } \\
\text { enterprise } 17\end{array}$ & $\begin{array}{l}\text { Service / } \\
\text { Software }\end{array}$ & Peru & $\begin{array}{l}\text { Strong } \\
\text { domesti } \\
\text { c ties }\end{array}$ & $\begin{array}{c}\text { Effectuati } \\
\text { on logic }\end{array}$ & 23 & 2008 / 2012 & $\begin{array}{l}\text { Germany, } \\
\text { Spain }\end{array}$ & $5 \%$ \\
\hline $\begin{array}{c}\text { Small } \\
\text { enterprise } 18\end{array}$ & $\begin{array}{c}\text { Manufacture / } \\
\text { Textiles \& } \\
\text { Apparel }\end{array}$ & $\begin{array}{c}\text { Colombi } \\
\mathrm{a}\end{array}$ & $\begin{array}{c}\text { Weak } \\
\text { domesti } \\
\text { c ties }\end{array}$ & $\begin{array}{l}\text { Effectuati } \\
\text { on logic }\end{array}$ & 17 & 2009 / 2013 & Mexico & $15 \%$ \\
\hline $\begin{array}{c}\text { Small } \\
\text { enterprise } 19\end{array}$ & $\begin{array}{l}\text { Agro industrial / } \\
\text { Fruit Pulps }\end{array}$ & Peru & $\begin{array}{c}\text { Weak } \\
\text { domesti } \\
\text { c ties }\end{array}$ & $\begin{array}{c}\text { Effectuati } \\
\text { on logic }\end{array}$ & 14 & 2008 / 2016 & $\begin{array}{l}\text { Holland, } \\
\text { Spain }\end{array}$ & $40 \%$ \\
\hline $\begin{array}{c}\text { Small } \\
\text { enterprise } 20\end{array}$ & $\begin{array}{c}\text { Manufacture / } \\
\text { Textiles \& } \\
\text { Apparel }\end{array}$ & $\begin{array}{c}\text { Colombi } \\
\mathrm{a}\end{array}$ & $\begin{array}{l}\text { Weak } \\
\text { domesti } \\
\text { c ties }\end{array}$ & $\begin{array}{c}\text { Effectuati } \\
\text { on logic }\end{array}$ & 28 & 2002 / 2009 & $\begin{array}{c}\text { Germany, } \\
\text { United } \\
\text { States, } \\
\text { and } \\
\text { Mexico }\end{array}$ & $15 \%$ \\
\hline $\begin{array}{c}\text { Small } \\
\text { enterprise } 21\end{array}$ & $\begin{array}{l}\text { Agro industrial / } \\
\text { Fruit Pulps }\end{array}$ & Peru & $\begin{array}{c}\text { Weak } \\
\text { domesti } \\
\text { c ties }\end{array}$ & $\begin{array}{l}\text { Effectuati } \\
\text { on logic }\end{array}$ & 12 & 2017 / 2017 & $\begin{array}{c}\text { United } \\
\text { States, } \\
\text { Canada, } \\
\text { England, } \\
\text { Germany, } \\
\text { Australia, } \\
\text { Japan, } \\
\text { Italy }\end{array}$ & $97 \%$ \\
\hline $\begin{array}{c}\text { Small } \\
\text { enterprise } 22\end{array}$ & $\begin{array}{l}\text { Agro industrial / } \\
\text { Fruit Pulps }\end{array}$ & Peru & $\begin{array}{c}\text { Weak } \\
\text { domesti } \\
\text { c ties }\end{array}$ & $\begin{array}{l}\text { Causation } \\
\text { logic }\end{array}$ & 42 & 2014 / 2015 & $\begin{array}{c}\text { Germany, } \\
\text { Holland, } \\
\text { United } \\
\text { States, } \\
\text { Canada, } \\
\text { Russia, } \\
\text { Poland, } \\
\text { Bulgari, } \\
\text { Leetonia, } \\
\text { Hungry, } \\
\text { Rumania, } \\
\text { Turkey, } \\
\text { Chile, } \\
\text { Malaysia, } \\
\text { Italy, } \\
\text { Argentina, } \\
\text { Portugal }\end{array}$ & $100 \%$ \\
\hline $\begin{array}{c}\text { Small } \\
\text { enterprise } 23\end{array}$ & $\begin{array}{l}\text { Service / } \\
\text { Software }\end{array}$ & Peru & $\begin{array}{l}\text { Strong } \\
\text { domesti } \\
\text { c ties }\end{array}$ & $\begin{array}{l}\text { Causation } \\
\text { logic }\end{array}$ & 15 & $2000 / 2009$ & $\begin{array}{c}\text { Colombia, } \\
\text { Ecuador, } \\
\text { Chile, } \\
\text { Argentina, } \\
\text { Panama, } \\
\text { Mexico }\end{array}$ & $50 \%$ \\
\hline $\begin{array}{c}\text { Small } \\
\text { enterprise } 24\end{array}$ & $\begin{array}{l}\text { Agro industrial / } \\
\text { Fruit Pulps }\end{array}$ & Peru & $\begin{array}{c}\text { Weak } \\
\text { domesti } \\
\text { c ties }\end{array}$ & $\begin{array}{l}\text { Effectuati } \\
\text { on logic }\end{array}$ & 50 & 2013 / 2014 & Italy & $100 \%$ \\
\hline
\end{tabular}




\begin{tabular}{|c|c|c|c|c|c|c|c|c|}
$\begin{array}{c}\text { Small } \\
\text { enterprise 25 }\end{array}$ & $\begin{array}{c}\text { Agro industrial / } \\
\text { Fruit Pulps }\end{array}$ & Peru & $\begin{array}{c}\text { Weak } \\
\text { domesti } \\
\text { c ties }\end{array}$ & $\begin{array}{c}\text { Effectuati } \\
\text { on logic }\end{array}$ & 12 & $2009 / 2011$ & $\begin{array}{c}\text { France, } \\
\text { Spain, } \\
\text { Finland }\end{array}$ & $87 \%$ \\
\hline
\end{tabular}

Source. Prepared by the author.

\subsubsection{Variables and measurement}

The study used well-established measures from existing research. In the present study, the outcome is accelerated internationalisation and it was measured according to the speed, extent, and scope of the internationalisation (Madsen, 2013; Weerawardena et al., 2007). In order to measure the causal conditions (type of relationship and decision-making logic), we contrast the answers of the open-ended questions with the answers of the five-point Likert scale. For instance, strong domestic ties were described in these words: Microenterprise 1 "we have mutual trust because we have known each other for a long time". Similarly, small enterprise 9 states "they have confidence in me. We do not compete, we are friends". On the other hand, weak domestic ties were described in these words: Microenterprise 2 "I did not know them well but they have really interesting information". Small enterprise 11 said, "the company wanted to know more about us, because they knew someone in Mexico that needed our product". After classifying the answers to the open-ended questions, we contrast it with the answers of the five-point Likert scale.

In the same way, the decision-making logic was categorized according to Sarasvathy's framework (Sarasvathy, 2001) and was identified following the instrument of Chandler et al. (2011). Effectuation logic was analyzed through the existence of these elements: experimentation, affordable loos, flexibility, or precommitments. For instance, small enterprise 1 mentioned that "we changed our business model to exploit the opportunity that was emerging" and "we knew how much we were willing to lose". Subsequently, we contrast these answers with the average of the fifteen items as the indicator of effectuation (Chandler et al., 2011). By doing this, we avoid the bias that may result from suggesting responses to individuals. 
The control variables included in our model are: 1) the existence of external barriers or internal barriers to export (Uner et al., 2013); 2) if the firm has been benefited from any export promotion program; and finally, 3) the size of the firm, measured by the number of employees because size mattered in the process of internationalisation (Kalantaridis \& Vassilev, 2011).

\subsubsection{Calibration}

The fsQCA approach requires specification of the values of an interval-scale variable. These values correspond to the threshold for full membership (fuzzy score $=0.95$ ), the crossover point (fuzzy score $=0.5$ ), and the threshold for full nonmembership (fuzzy score $=0.05$ ) (Ragin, 2008; Woodside, 2013). Accordingly, original scaled values should be transformed into fuzzy-set membership scores for all conditions and outcomes based on substantive, theoretical knowledge (Ragin, 2008). During data analysis and calibration, the iteration between data and theory was constant. In fact, other scholars checked the accuracy of the categorization and calibration. Furthermore, calibration was implemented using the direct method and according to the guidelines that were presented by Ragin (2008).

The next step is to use the fsQCA truth table algorithm to generate different combinations of causal conditions that are sufficient for achieving accelerated internationalisation. By setting the consistency cut-off value to 1.0, this research distinguishes between configurations that are sufficient for the outcome and configurations that are not (Fiss, 2011). Given the unresolved question about which causal conditions contribute to accelerated internationalisation among SMEs from contexts with institutional voids, and the arguments concerning the value of fsQCA as a methodological approach, this study combines theoretically relevant antecedents to explore the configurations that are the most promising for explaining accelerated internationalisation. 


\subsection{Results}

By combining the domestic networking activity (Söderqvist \& Chetty, 2013) and the decision-making logic (Sarasvathy, 2001), this research explores when and under what circumstances the internationalisation process of SMEs in contexts with institutional voids is accelerated. For this reason, we have used the fuzzy-set qualitative comparative analysis of the 33 cases. The case data reveal that overall, accelerated internationalisation is fostered by the type of domestic relationship with a combination of the decision-making logic. The results indicate that in most cases, weak domestic ties and effectuation logic behavior lead to accelerated internationalisation of SMEs with fewer resource constraints. In contrast, strong domestic ties and causation behavior lead to accelerated internationalisation of SMEs with greater resource constraints. Table 9 and table 10 shows the intermediate solution for Colombia and Peru with the causal configurations for achieving accelerated internationalisation.

\section{Table 9. The causal configurations for achieving accelerated internationalisation of SMEs in Colombia}

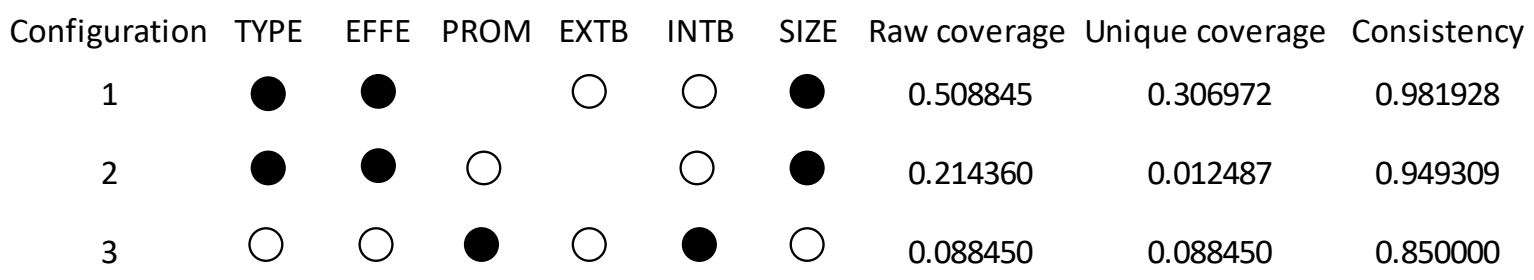

Solution coverage: 0.609781

Solution consistency: $\quad 0.943639$

Note: [TYPE]=Type of relationship; [EFFE]= Decision-making logic; [PROM]= Export promotion program; [EXTB]= External barriers to export; [INTB]= Internal of barriers to export. [SIZE]= Size of the enterprise.

Note: Black circles indicate the presence of a causal condition and white circles indicate the absence or negation of a condition. These are common denominations in the presentation of fsQCA results.

Source. Prepared by the author 
The results of the Colombian cases imply that weak domestic ties and effectuation logic accelerated the internationalisation of small firms in Colombia. Particularly, the first configuration of the fsQCA shows that: (a) weak domestic ties, (b) effectuation logic, and (c) absence of internal and external barriers lead to accelerated internationalisation. Both, consistency and raw coverage are high due to this configuration. Similarly, the second configuration points out that: (a) weak domestic ties, (b) effectuation logic, (c) not being benefited by an export promotion program, (d) absence of internal barriers, and (e) small enterprises, lead to accelerated internationalisation. The first two configurations reveal that resource-constrained SMEs that do not have internal barriers (such as being limited in information to analyze the market, the inability to contact foreign customers, the lack of managerial time to deal with exports, among others) can take advantage of their weak connections in order to identify foreign opportunities in a serendipitous way (Uner et al., 2013).

Finally, the third configuration shows that in SMEs with greater resource constraints: (a) strong domestic ties, (b) causation logic, (c) being benefited by an export promotion program, (d) absence of external barriers, and (e) existence of internal barriers, lead to accelerated internationalisation. 


\section{Table 10. The causal configurations for achieving accelerated internationalisation of SMEs in Peru}

\begin{tabular}{|c|c|c|c|c|c|c|c|c|c|}
\hline Configuration & TYPE & EFFE & PROM & EXTB & INTB & SIZE & Raw coverage & Unique coverage & Consistency \\
\hline 1 & 0 & 0 & $\bigcirc$ & 0 & $\bigcirc$ & $\bigcirc$ & 0.0803357 & 0.0803357 & 1 \\
\hline 2 & 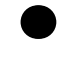 & $\bigcirc$ & $\bigcirc$ & $\bigcirc$ & $\bigcirc$ & & 0.0803357 & 0.0803357 & 1 \\
\hline 3 & & 0 & & $\bigcirc$ & 0 & $\bigcirc$ & 0.0803357 & 0.0803357 & 1 \\
\hline 4 & & & $\bigcirc$ & $\bigcirc$ & & 0 & 0.0803357 & 0.0803357 & 1 \\
\hline 5 & $\bigcirc$ & $\bigcirc$ & & $\bigcirc$ & & & 0.0995204 & 0.0143886 & 0.813725 \\
\hline 6 & $\bigcirc$ & 0 & & & & 0 & 0.159472 & 0.0743405 & 1 \\
\hline 7 & & & & $\bigcirc$ & $\bigcirc$ & 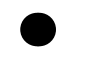 & 0.142686 & 0.0803357 & 1 \\
\hline 8 & & & & & & $\bigcirc$ & 0.141487 & 0.0791367 & 0.880597 \\
\hline Solution cove & & & & & & & & & \\
\hline
\end{tabular}

Note: $[$ TYPE] $=$ Type of relationship; $[$ EFFE] = Decision-making logic; $[\mathrm{PROM}]=$ Export promotion program; [EXTB]= External barriers to export; [INTB]= Internal of barriers to export. [SIZE]= Size of the enterprise.

Note: Black circles indicate the presence of a causal condition and white circles indicate the absence or negation of a condition. These are common denominations in the presentation of fsQCA results.

Source. Prepared by the author

The results of the Peruvian cases suggest a remarkable and similar pattern that the one observed in Colombia. The first, fifth and sixth configurations of the Peruvian cases are quite similar to the third configuration of the Colombian cases. These configurations confirm that strong domestic ties combined with causation logic accelerate the internationalisation. Indeed, it seems that SMEs that rely on strong domestic networks tend to use only causation logic. Moreover, the configurations reveals that most of these firms have internal barriers and have been benefited by an export promotion program. In other words, SMEs must rely on networks were they know each other well and have emotional ties to overcome their internal barriers 
to export (Stam, Arzlanian, \& Elfring, 2014). Because in causation logic the firm needs to process a significant amount of information, external help such as the one provide by Export Promotion Agencies will contribute to the internationalisation process (Kalinic et al., 2014; Leonidou, Palihawadana, \& Theodosiou, 2011). Because one of the purposes of export promotion programs is to develop a planned internationalisation strategy, then firms that participate in such programs end up using causation logic. It might happens because the internationalisation strategy that is planned is based on goal-driven action, dependence on competitive analysis, expected returns, exploiting pre-existing knowledge, and predictions of the future.

Considering the fourth, seventh and eighth configurations of the Peruvian cases and, the first and second configuration of the Colombian cases, it appears that weak domestic ties combined with effectuation logic accelerate the internationalisation of SMEs located in contexts with institutional voids. The results are consistent with similar studies (Chandra et al., 2009; Galkina \& Chetty, 2015; Kalinic et al., 2014). This finding suggests that in order to speed the internationalisation process, SMEs should focus on its weak domestic ties, use its partner's resources, and get access to novel information. By doing this, the SMEs will discover and take advantage of new foreign opportunities, spurring the speed, scope, and extent of its internationalisation process.

A difference between the configurations of the two countries is that the second and third configuration of the Peruvian cases, show that firms can have weak domestic ties and use causation logic to reach accelerated internationalisation. A possible explanation for these dissimilarities arises from the impact of institutional uncertainty on the decision making process of the firm. According to Laine y Galkina (2017), an increase of institutional uncertainty boost effectuation. This means that we can expect that Peruvian SMEs that perceive lower institutional uncertainty may use causation logic instead of effectuation logic. Regarding the absence of internal and external barriers, even though it makes internationalisation easier, absence itself is not enough to stimulate internationalisation (Wood, Logar, \& Riley, 2015). 
Additionally, the negative impact of internal and external barriers is substantially reduced when the firm starts its internationalisation process (Uner et al., 2013).

The findings offer a solid foundation for the development of an integrative model with the combinations of conditions that lead to accelerated internationalisation (Figure 11). Based on the three configuration of the Colombian cases and the three configurations of the Peruvian cases that have the highest raw coverage (configurations sixth, seventh and eighth), we can conclude that the combination of weak domestic ties and effectuation decision-making logic accelerates internationalisation by following two different paths.

Figure 11. Integrative model for accelerated internationalisation

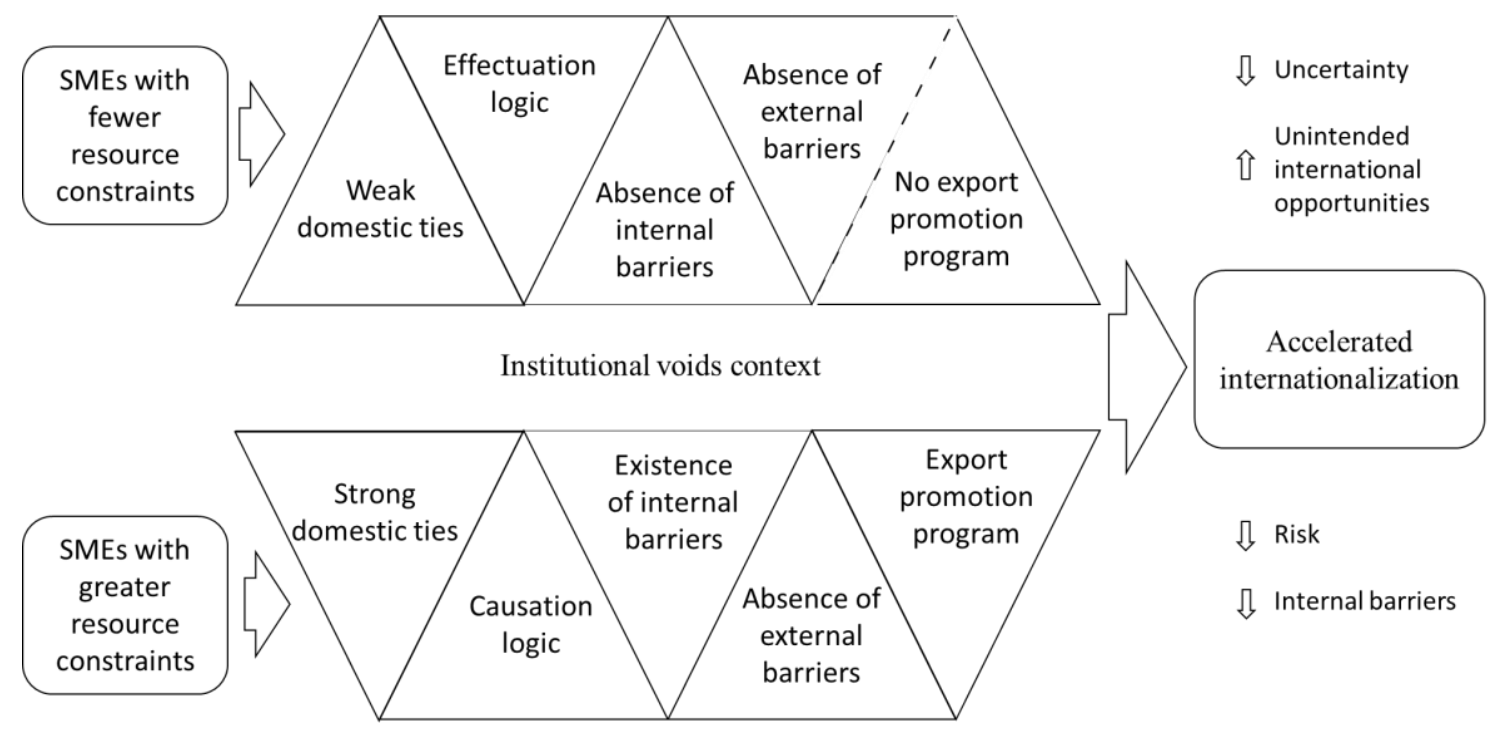

Source. Prepared by the author

The difference between the accelerating path that should follow SMEs might be explained by the variance of the capabilities of the firm (resources constraints and internal barriers). First, as a result of size, microenterprises face greater resourcerelated constraints than small enterprises (Gordon \& Suominen, 2014). This means that microenterprises have less resource to create, manage, and sustain weak domestic ties, which required more resources than strong connections (Ellis, 2000). Second, firms usually consolidate their strong relationships first, and as a 
consequence, they get access to weak ties (Agndal, Chetty, \& Wilson, 2008). Ergo, due to the lack of resources, there are lower chances that SMEs with greater resource constraints are able to consolidated weak domestic ties.

Third, the existence of internal barriers such as limited information about the foreign market, problems to identify international opportunities, difficulties to adapt the product according to the foreign market, among others (Uner et al., 2013) negatively affect the accelerated internationalisation of the firm (Bianchi \& Wickramasekera, 2016). Thus, SMEs with greater resource constraints could work with their strong networks, get involved in export promotion programs, and develop a planning strategy to overcome its limited capabilities (resource constraints and internal barriers). Finally, it is common that SMEs with greater resource constraints do not assume international risk unless they see tangible benefits (Martín-Tapia, AragónCorrea, \& Rueda-Manzanares, 2010). For this reason, causation as a mean to reduce risk and generate the expected returns is the most appropriate decision (Sarasvathy, 2001). Indeed, firms use causation logic when they want to reduce risk (Chetty et al., 2015). Likewise, strong ties also reduce the risk created by institutional voids (Kiss \& Danis, 2008). The combination between strong domestic ties, causation logic, existence of internal barriers, and being benefited by an export promotion program explain the accelerated internationalisation of SMEs with greater resource constraints in contexts with institutional voids.

In opposite direction, SMEs with fewer resource constraints can use their resources to create, manage, and sustain weak domestic ties to access to novel information and identify international opportunities (Galkina \& Chetty, 2015; Granovetter, 1973; Kontinen \& Ojala, 2011; Rindfleisch \& Moorman, 2001). Similarly, effectual logic suggests that firms should be open to a variety of new weak ties to pursue new opportunities in the foreign market (Kalinic et al., 2014). In fact, firms use effectual logic to manage uncertainty and create opportunities (Chetty et al., 2015). Hence, the rational of creating weak domestic ties is coherent with the purpose of using an effectual logic. These causal conditions combined with the absence of internal barriers enable the SMEs to exploit the identified international opportunity. 
Furthermore, the absence of external barriers and the fact of not being benefited by an export promotion program also contribute to achieve accelerated internationalisation. Finally, because effectuation logic is more effective in uncertain situations (Sarasvathy, 2008), it seems that SMEs with fewer resource constraints can use this type of logic to overcome the uncertainty created by their context of institutional voids (Ciszewska-Mlinaric et al., 2016).

\subsection{Conclusions}

This article has provided empirical evidence to address three shortcomings in the literature. First, the mixed results regarding the impact of strong and weak domestic ties and decision-making logic in the accelerated internationalisation of SMEs; second, the limited research on domestic networks (Prashantham \& Birkinshaw, 2015); and third, the scarce investigation in countries characterized by institutional voids (Haddoud et al., 2017; Knight \& Liesch, 2016). Finally, we use fsQCA to provide a dynamic perspective about accelerated internationalisation. Thus, two propositions were proposed to be tested in a context of institutional voids: 1) strong domestic ties combined with causation logic accelerate the internationalisation of firms with greater resource constraints that are located in countries characterized by institutional voids, and 2) weak domestic ties combined with effectuation logic accelerate the internationalisation of firms with fewer resource constraints that are located in countries characterized by institutional voids.

Building on the multidimensional conceptualization of accelerated internationalisation (Madsen, 2013; Weerawardena et al., 2007), on the relational embeddedness of the network (Söderqvist \& Chetty, 2013), and the decision-making logic (Sarasvathy, 2001), this research extends the understanding of the factors that contribute to accelerate the internationalisation of SMEs in contexts with institutional voids, by making several theoretical contributions. First, we found an explanation for the mixed results on which type of domestic network (strong or weak) boosts accelerated internationalisation. Based on 33 contrarian case studies and using fuzzy-set qualitative comparative analysis, we found that according to the resource 
constraints of the firm, the combination of strong or weak domestic ties and different decision-making logic enhance accelerated internationalisation in different ways. We also found that weak domestic ties and effectuation behavior lead to accelerated internationalisation of small enterprises, while strong domestic ties and causation logic lead to accelerated internationalisation of microenterprises. More specifically, this research showed that SMEs with fewer resource constraints accelerate their internationalisation process through the combination of weak domestic ties, effectuation logic, and the absence of internal barriers. In contrast, strong domestic ties, causation logic, the fact of being benefited by an export promotion program, absence of external barriers, and the existence of internal barriers lead to accelerated internationalisation of SMEs with greater resource constraints.

Second, we confirmed that effectuation and causation logic change according to the circumstances and the environment of the firm (Sarasvathy, 2008). The preceding analysis leads us to propose an integrative model for accelerated internationalisation. The proposed model suggests that the differences of the capabilities of the firm might explain the different paths that SMEs should follow in order to reach accelerated internationalisation. It seems that the variance of resources and internal barriers among SMEs explain the differences of the combination that accelerated internationalisation. SMEs with greater resource constraints usually face internal barriers to export (Gordon \& Suominen, 2014). Therefore, microenterprises reduce the risk associated with internationalisation by exploiting their existing strong relationships (Ellis, 2000; Söderqvist \& Chetty, 2013). They also use their domestic strong ties and export promotion programs to overcome their internal barriers to export. This behavior is consistent with the preference for causation logic (Chetty et al., 2015; Sarasvathy, 2008).

Finally, inspired by calls for holistic approaches that contribute to understand the factors that accelerate internationalisation (Bell, Crick, \& Young, 2004; Chetty \& Campbell-Hunt, 2004; Chetty et al., 2014; Jones \& Coviello, 2005), we provide a dynamic perspective. By using fsQCA, the study considers multilevel explanations and different causal paths that are satisfactory for accelerated internationalisation. 
For the firms that are interested in accelerating their internationalisation process, our findings reveal important insights. First, the manager should identify its resource constraints and its internal barriers to export. According to the findings, the firm should consciously create and develop domestic networks with either strong or weak ties. Strong domestic ties combined with causal logic and the participation on export promotion programs should be seen as an important source to reduce risk and to overcome lack of resources and internal barriers to export. By doing this, the company will be able to reach accelerated internationalisation. On the other hand, weak domestic ties combined with effectuation logic, should be seen as an important source to manage uncertainty and to find unintended international opportunities. As a consequence, firms will be able to accomplish accelerated internationalisation. The results also highlight the need to create different export promotion instruments according to the capabilities of the firm. SMEs with greater resource constraints might be benefited from the creation of export plans that have the following characteristics: they are goal-driven, they include competitive analysis, expected returns are accounted, and they use existing market knowledge. In yet contrast, SMEs with fewer resource constraints might need strategies that help them create and develop weak domestic ties.

\subsection{Limitations and future research directions}

This study has limitations that represent opportunities for future research. First of all, the causal conditions on which we focused, although significant, are not necessarily exclusive. Second, this study focuses solely on Colombia and Peru. The results may therefore differ in other country and cultural environment. Therefore, examining cross-countries longitudinal case studies would provide interesting insights and enrich the unique cultural contexts presented in this article. Third, some studies have shown that once the firms accelerate internationalisation, they might switch their effectuation logic (Gabrielsson \& Gabrielsson, 2013; Kalinic et al., 2014). Future research may focus on this process, investigate further if once the firms reach accelerated internationalisation, the embeddedness of the network or/and the effectuation logic changes. Finally, more research is needed on the differences 
between SMEs with greater resource constraints and SMEs with fewer resource constraints. 


\section{Chapter four- The fast lane of internationalisation of Latin American SMEs: Effectual networks, institutional voids and location effects}

\subsection{Introduction}

In the past two decades, the phenomenon of accelerated internationalization has attracted much research attention (e.g. Jones, et al., 2011; Kiss, et al., 2012; Knight \& Cavusgil, 2004). Despite the limited financial, human, and tangible resources that usually characterize Small- and Medium-sized enterprises (SMEs), some of these firms achieve considerable success in international business early in their development (Autio, et al., 2000; Oviatt \& McDougal, 2005). However, little attention has been devote to explore the influence of effectual networking and institutional voids on accelerated internationalization (Prashantham, et al., 2019; Read, et al., 2016; Reuber, et al., 2016), and the impact of location on accelerated internationalization (Bianchi \& Wickramasekera, 2016; Torkkeli, et al., 2019). Similarly, there is a need to extent the scarce research of the effect of domestic network ties and studies on Latin American SMEs (Milanov \& Fernhaber, 2014; Prashantham \& Birkinshaw, 2015; Torkkeli \& Fuerst, 2018). Finally, there is a gap in the literature regarding the micro-mechanisms behind accelerated internationalization (Casillas \& Acedo, 2013; Coviello, 2015; Madsen, 2013). Therefore, this study extends the literature by clarifying the micro-mechanisms that connect the impact of location, institutional voids, effectual networking and domestic network strength on the accelerated internationalization of Latin American SMEs.

Scholars recommended that the measurement of accelerated internationalization should incorporate indicators of extent (international sales are above $25 \%$ of total sales); scope (high dispersion of activities across foreign countries) and; speed (the time between inception and first international sales is 3 years or less; Kuivalainen, et al., 2012; Madsen, 2013; Weerawardena et al., 2007; Zahra \& George, 2002). They have also assert that this process differs significantly between developed and developing economies (Ciravegna, et al., 2016; Cuervo-Cazurra, et al., 2018; Narooz \& Child, 2017). While SMEs located in developed economies tend to have 
particular home-based advantages; in contrast, enterprises in developing economies have to deal with much more limited resources and, overall, institutional voids. Similarly, firms located in rural cities tend to have more institutional voids and less access to resources than firms located in first- and second-tier cities (Mair, et al., 2012). Moreover, firms located in first- and second-tier cities may benefit form agglomeration economies and spatial externalities such as specialized infrastructure, inter-firm knowledge exchange and development of innovation capability (Hervas-Oliver, et al., 2018; Westhead, et al, 2004). Likewise, exporters are usually located in first- and second-tier cities to take advantage of dense sector and domestic networks (Spence, et al., 2011). Finally, it is easier for first- and second-tier cities firms to gain access to high skilled and knowledge-intensive services (Shearmur \& Doloreux, 2008). Consequently, firms located in first- and second-tier cities are more likely than rural firms to become international (Chevassus-Lozza \& Galliano, 2003).

Uncertainty engendered by institutional voids may hamper a firm's competitiveness (Calvo, et al., 2006; Lingelbach, et al., 2015) and affects the firm's internationalization process (Khanna, et al., 2005; Santangelo \& Meyer, 2011; Verreynne, et al., 2016). On the one hand, institutional voids lessen the possibility to access strategic resources and increase the operational costs of the firm, reducing its competitiveness (Cuervo-Cazurra, 2012; Hitt, et al., 2005; Sharma, 2011). Therefore, institutional voids, may negatively affect the accelerated internationalization of the firms (Cardoza et al., 2016; He \& Cui, 2012). However, on the other hand, firms might internationalize as an escape response to institutional voids (Witt \& Lewin, 2007; Yamakawa, et al., 2008). The uncertainty created by institutional voids can push firms to develop special advantages and explore international opportunities to diversify risk (Cuervo-Cazurra, et al,, 2018; Jones, 2012; Luo, et al., 2010). While international business literature has dissipated doubts on how uncertainty created by institutional voids determines a firm's ability to internationalize (see Khanna \& Palepu, 2000; Su, et al., 2017; Volchek, et al., 2013) the influence of uncertainty on accelerated internationalization has been scarcely assessed and represents a potential area for fruitful research (Bianchi \& 
Wickramasekera, 2016; Torkkeli, et al., 2019). Likewise, despite the relevance of the aforementioned studies, there is scant empirical evidence on the effect of the geographical location and more specifically, the effect of the local context, on the explanation of the accelerated internationalization of the firm (Adomako, et al., 2019; Matteis, et al., 2019).

The network approach highlights the importance of network ties on compensating for uncertainty and reaching accelerated internationalization (Belso-Martínez, 2006; Chetty \& Agndal, 2007; Galkina \& Chetty, 2015; Hilmersson \& Jansson, 2012; Srivastava, et al., 2018). Network scholars argue that firms lever domestic or international (foreign) ties to seek opportunities in international markets and deal with uncertainty (Geoffrey, 2012; Montoro-Sanchez, et al., 2018; Yamakawa, et al., 2008). Particularly, firms tend to use pre-commitments within their domestic and international network ties to acquire specific knowledge that may help them to reduce uncertainty (Fiedler, et al., 2016; Khanna \& Palepu, 2010).

However, the role of inter-firm linkages in reducing uncertainty and accelerating internationalization largely depends on the strategic orientation of networking dynamics. The effectuation (causation) logic provides a new lens to explain how firm use their network ties to accelerate their internationalization process (Sarasvathy, 2001). Effectual networking consists in forming partnerships to jointly co-create the future. Conversely, firms following a causation logic, build networks based on a predetermined goal and select resources. This embryonic approach taken by mergers with regard to effectuation and internationalization have refined our understanding of the Uppsala Model (Galkina \& Chetty, 2015; Vahlne \& Johanson, 2017), but a lot remains to be done in born-global or accelerated internationalization models. Scant empirical evidence just endorses the positive influence of effectual networks on the acceleration of the internationalization process (Kalinic, et al., 2014; Prashantham, et al., 2019).

This article contributes to this novel research stream by clarifying the micromechanisms that connect the impact of location, institutional voids, effectual networking and network strength on the accelerated internationalization of Latin 
American SMEs. Drawing on the existing literature, we develop and test a set of hypotheses that include both mediation effects and multiple interactions. We specifically analyze how first-tier cities, second-tier cities and rural cities, level of country institutional voids, effectual networking and strong (weak) domestic ties contribute to a higher likelihood of accelerated internationalization and the moderator effect of interaction between location, institutional voids, effectual networking and domestic network strength. By doing so, we respond to recent calls to incorporate effectuation research into institutional voids (Read, et al., 2016; Reuber, et al., 2016). In addition, further empirical evidence on the influence of effectual networking on accelerated internationalization (Prashantham, et al., 2019) and the impact of location on accelerated internationalization is obtained (Bianchi \& Wickramasekera, 2016; Torkkeli et al., 2019). Our database of 2.987 Latin American SMEs provides a unique opportunity to test the specificity of our theoretical constructs in developing economies, which may be especially effective due to their well-known institutional voids (Lingelbach et al., 2015; Pawęta, 2016). This database is considerably higher than similar international business studies (Robson, et al., 2012; Yang, et al., 2006).

This paper is organized as follow: The next section outlines the theoretical framework for this research. This is followed by the methodology employed and the findings relating to the hypothesis of interest. The paper ends with the empirical results, discusses their theoretical and practical implications, addresses the study's limitations, and suggests avenues for future research.

\subsection{Theory and hypotheses}

\subsubsection{Spatial dimension, institutional voids and accelerated internationalization}

Research on the relevance of the geographical location has proved to be a crucial factor in explaining the internationalization process of the firm (Yeung, 2009). This relevance is specially consistent for the internationalization performance of SME's in developing economies (Freeman, Styles, \& Lawley, 2012). Thanks to geographical proximity in urban areas or industrial clusters, firms may access specialized 
infrastructure, knowledge exchanges and development of novel solutions (HervasOliver et al., 2018) that subsequently speed up their internationalization (Zahra \& George, 2002). Particularly, frequent face-to-face interactions facilitate the creation of dense networks of strong ties through which firms share fine-grained technical and managerial knowledge in an atmosphere of trust (Balland, et al., 2016; MolinaMorales, et al., 2015).

Further, empirical literature has identified that city size is also relevant. First-tier cities generally provide industrial diversity that facilitates knowledge-sharing and the creation of new firms (Duranton \& Puga, 2001). They also provide large local human resources, facilitate the access to specialized infrastructure, decreasing the cost of information flows (Audretsch \& Feldman, 2004). Moreover, first- and second-tier cities offer a large pool of suppliers and reduce search costs that can positively impact opportunity discovery (Herstad \& Ebersberger, 2015). They enhance interfirm knowledge exchange and the development of innovation capability (HervasOliver et al., 2018). In contrast, firms established in rural cities are usually constrained by an unsophisticated market, difficulty in accessing strategic resources and therefore, present little specialization (Cuervo-Cazurra, 2012; Sharma, 2011). As a consequence, firms located in first- and second-tier cities are more likely to become international than firms located in rural cities (Spence, Orser, \& Riding, 2011). Thus, we propose the following hypothesis:

H1: Firms located in first- and second-tier cities have a higher likelihood of accelerated internationalization.

Literature suggests that in general terms, cities that faced low institutional voids, are more prone to present accelerated internationalization than cities with high institutional voids (Cardoza, et al., 2016; He \& Cui, 2012; Johanson \& Vahlne, 2009). Institutional voids are present in a country or regions when "institutional arrangements that support markets are absent, weak, or fail to accomplish the role expected of them" (Mair \& Marti, 2009, p 422). Such a situation is expected to cause political instability and corruption (De Clercq \& Bowen, 2008) and are a common characteristic of developing economies (Khanna et al., 2005). 
Institutional voids also imply a lack of institutional support, financial assistance and international market information (Khanna \& Palepu, 2010) which is more accentuated in rural areas (Mair, et al., 2012). Moreover, the unnecessary legal, political and economic challenges that institutional voids create, add costs and reduce international firm performance (Tang, et al., 2014; Torkkeli \& Fuerst, 2018). It has been suggested that even if a firm benefits from government internationalization support, institutional voids lessen its internationalization speed (Kaur \& Sandhu, 2014).

However, institutional voids may encourage firms to explore international opportunities to diversify risk (Aulakh \& Kotabe, 2008; Cuervo-Cazurra, et al., 2018; Jones, 2012). To explain this effect, scholars have proposed the institutional escapism view (Witt \& Lewin, 2007; Yamakawa et al., 2008). This view suggests that firms based in a context of institutional void, internationalize more aggressively than firms located in a context of strong institutions (Luo et al., 2010). For some firms, institutional voids have become a training ground to develop advantages through their exposure to uncertainty, which lead them to achieved accelerated internationalization (Cuervo-Cazurra, et al., 2018). Moreover, uncertainty can push firms to develop resources and capabilities needed for fast foreign market expansion (Witt \& Lewin, 2007). Finally, institutional voids may also motivate firms to create informal domestic networks that help them to internationalize (Narooz \& Child, 2017). In view of these contradictory arguments, we propose the following hypothesis:

$\mathrm{H} 2$ : Institutional voids influence the acceleration of the internationalization process.

\subsubsection{Uncertainty, effectual networks and accelerated internationalization}

Effectuation logic is a decision-making process that consists in mobilizing the resources and capacities of their network that are within their control to co-create the future (Sarasvathy, Kumar, York, \& Bhagavatula, 2014). In particular, firms who use effectuation logic are able to create new international opportunities and expand their resources, despite the uncertain environment (Sarasvathy, 2001). Given the complementariness between effectuation theory and the internationalization process 
of SMEs, the main internationalization theories of SMEs have integrated this concept into their frameworks (Gil-Barragan, et al., 2020a; Karami, et al., 2019; Matalamäki, 2017).

Particularly, Harms and Schiele (2012) suggest that since internationalization deals with decision making under uncertainty, experienced entrepreneurs tend to apply effectual logic, rather than causation, to select the entry mode. Moroever, Schweizer, et al (2010) explicitly include effectuation logic in the Uppsala model by considering the entrepreneurial capabilities and the exploitation of contingencies. This means that firms that use effectuaton logic are able to turn unpredictable events into opportunities. Similarly, Andersson (2011) showed that born global firms, usually use effectuation logic to identify international opportunities by co-operating with local network partners. Therefore, he recommended that effectuation should be included in future research on born globals. Consequently, effectuation has increasingly been applied to explain the internationalization of SMEs (Pawęta, 2016; Sarasvathy et al., 2014).

More recently, Galkina and Chetty (2015) have used the concept of effectual networks to examine how SMEs identify international opportunities. The Effectual networking suggests that firms engage in conversations with a variety of people with whom they end up making pre-commitments to co-create opportunities (Lingelbach et al., 2015; Pawęta, 2016). On one hand, pre-commitments provide support for exploration and experimentation (Sarasvathy \& Dew, 2005). This happens because partners bring new ideas, solutions, knowledge, resources and time (Servantie \& Rispal, 2018). Among partners, it seems that customers easily get involved and contribute to the co-creation processes of new products (Coviello \& Joseph, 2012). On the other, through co-creation of opportunities, firms receive faster feedback at a lower cost and distribute risk and cost among stakeholders (Read, et al., 2009). This enables the firm to bring new products to the market sooner. Therefore, networks, pre-commitments and co-creation of opportunities are foundational to effectuation theory (Kerr \& Coviello, 2019a; Sarasvathy, 2001, 2009). 
To the best of our knowledge, the few studies that investigate the influence of effectual networking on accelerated internationalization suggest a positive relationship. Kalinic et al. (2014) found that effectual networks ease the amount of information required to enter a new market and thus, allow acceleration of the internationalization process. Similarly, Prashantham et al. (2019) suggest that effectual networks accelerate internationalization because firms do not have the need to define and search for the ideal partner. Consequently, they create larger networks that moderate the risk of internationalization and embrace new opportunities. Both studies stress the importance of being open to a variety of new potential partners, and select those who are willing to co-create opportunities, such as new products. Based on this framework, we propose the following hypothesis:

H3: Firms that use effectual networks have a higher likelihood of accelerated internationalization.

As mentioned before, under conditions of uncertainty, firms consider effectuation instead of causation (Read et al., 2016). Conceptually, effectual networking decreases uncertainty by co-creating new opportunities and transforming accessible means into new goals (Kerr \& Coviello, 2019b; Kubberød, et al., 2019). Moreover, effectual networks mitigate concerns about an uncertain future (Sarasvathy et al., 2014). Finally, firms located in context with high institutional voids tend to face high levels of uncertainty (Adomako et al., 2019). Therefore, we expect that the extent to which a firm located in high institutional voids, adopts effectual networking, will be positively associated with a firm's internationalization. Based on this theorizing, we propose the following:

H4: Firms located in a context of significant institutional voids which also have effectual networking, have a higher likelihood of accelerated internationalization. 


\subsubsection{Uncertainty, network strength and accelerated internationalization}

Similar to effectuation logic, literature confirms that networks contribute to the accelerated internationalization process by allowing firms to access new resources (Coviello, 2006) and identify international opportunities (Ellis, 2011; Oviatt \& McDougal, 2005). However, this process might be moderated by the strength of network ties and their location (Leppäaho, et al., 2018). Networks can be classified into strong or weak ties, depending on the amount of time, trust, emotional intensity and intimacy (Granovetter, 1973). Strong ties are defined as those that have active participation and commitment, with frequent interaction and mutual trust. In contrast, weak ties display passive participation and commitment, with infrequent interaction (Söderqvist \& Chetty, 2013). It has been shown that both strong and weak ties help firms to internationalize rapidly (Chandra, et al., 2009; Söderqvist \& Chetty, 2013). On one hand, strong network ties accelerate internationalization through knowledge sharing and resource exchanging; on the other, weak ties act as bridges to novel information, supporting innovation and creativity (Hayton, et al., 2011; Johanson \& Vahlne, 2006; Uzzi, 1997). However, among them, it seems that strong ties are more relevant than weak ties in the early phases of a firm's accelerated internationalization process (Gulati, et al., 2011; Söderqvist \& Chetty, 2013)

Regarding the location of the networks, it has been widely demonstrated that international networks ties support accelerated internationalization by providing internationalization knowledge (Dimitratos, et al., 2014; Knight \& Cavusgil, 2004; Oviatt \& McDougal, 1994) and international opportunities (Chetty \& Agndal, 2007; Ellis, 2000). More recently, scholars have focused on the role of domestic network ties on accelerated internationalization. By collaborating with domestic network ties, firms are also able to accumulate internationalization knowledge (Ryan, et al., 2019), increase their propensity to export (Boehe, 2013) and access to international network ties (Montoro-Sanchez et al., 2018). It seems that the close proximity of strong domestic ties provides additional motivation to transmit knowledge and show a cooperative behavior (Asheim \& Gertler, 2005). For instance, the trust atmosphere of domestic strong ties reduces the opportunistic behaviors of the network members 
(Dettmann \& Brenner, 2010). Thus, firm knowledge sharing and resource exchanging that take place among strong ties might be enhanced by local close proximity (Westhead et al., 2004). Therefore, we propose the following hypothesis:

H5: Firms that have strong domestic ties have a higher likelihood of accelerated internationalization.

Moreover, the impact that strong domestic ties have might change according to the size of the firm (Gil-Barragan et al., 2020b). It seems that because weak domestic ties are costly to build and maintain, smaller firms tend to rely more on strong domestic ties than on weak domestic ties (Agndal, et al., 2008). For instance, Cardoza, et al. (2016) found that in Latin America, strong domestic ties are more efficient than weak domestic ties to enhance the internationalization process of the smaller firms. In contrast, there are higher chances that larger firms with greater resources are able to consolidated weak domestic ties that help them to internationalize (Agndal et al., 2008). Larger firms use weak ties to share novel information, identify international opportunities, and therefore, accelerate internationalization (Galkina \& Chetty, 2015; Kontinen \& Ojala, 2011). Thus, we propose the following hypothesis:

H6: The size of the firm moderated the impact of strong domestic ties on the likelihood of accelerated internationalization.

Similarly, as discussed earlier, firms located in first- and second-tier cities have greater opportunities to benefit from agglomeration economies (Westhead et al., 2004). First- and second-tier cities attract similar and supporting industries that facilitate knowledge and idea sharing, and enable mobility of a skilled workforce (Saxenian, 1994). These cities also provide access to financial institutions, government assistance and export-related infrastructure (Fuller-Love, et al., 2006; Wright, et al., 2007). Moreover, first- and second-tier cities facilitate access to proximate resources and enable the creation of strong network ties, which has special relevance for the survivor and internationalization of young entrepreneurial firms (McCann \& Folta, 2011; Mittelstaedt, et al., 2006). Consequently, firms located in these kind of cities might achieve a higher degree of accelerated 
internationalization, compared to their counterparts in rural cities (North \& Smallbone, 2000; Spence et al., 2011). Based on this theorizing, we propose the following hypothesis:

$\mathrm{H} 7$ : Firms that have strong domestic ties and are located in first- and second-tier cities have a higher likelihood of accelerated internationalization.

\subsection{Method}

\subsubsection{Research design and context}

For our analysis, we use firm-level data for Argentina, Colombia and Peru from the World Bank's Enterprise Surveys (ES) database. The World Bank collects the data systematically, using standardized surveys and stratified sampling techniques to ensure representative coverage for a given country. This allows comparison among countries. The ES has been used and validated by academics from international entrepreneurship research of emerging economies (e.g., Deng \& Zhang, 2018; Krammer, et al., 2018; Wu, 2016).

We focus on Latin American countries because this region is underrepresented and has been neglected in international entrepreneurship research (Torkkeli \& Fuerst, 2018). Moreover, most of the scarce research on Latin America has focused on multinational enterprises (Ciravegna et al., 2016). However, SMEs located in Latin American countries are showing global orientation that deserves more research (Frechette, 2006). Additionally, Latin America is an interesting setting because the SMEs that are gaining international relevance are highly dependent on the export of natural resources (Dimitratos et al., 2014). It means that the accelerated internationalization process of these SMEs might differ from the traditional accelerated internationalization firms that belong to high-tech sectors. Finally, although it has been demonstrated that institutional voids are a key mediator in the internationalization process of Latin American SMEs (Vassolo, at al., 2011), it has been also suggested that institutional voids impact differently on Latin American SMEs' international expansion than SMEs from other regions (Cardoza, et al., 2016). 


\subsubsection{Dependent variable}

The degree of accelerated internationalization is our dependent variable and was obtained from the 2017 release of ES, which includes 991 SMEs from Argentina, 993 SMEs from Colombia and 1,003 SMEs from Peru. Accelerated internationalization, has been defined in terms of the length of time between inception and first international sales (speed); the number of foreign countries in which sales are generated (scope), and the percentage of foreign on total sales (extent; Kuivalainen, et al., 2007; Weerawardena et al., 2007; Zahra \& George, 2002). This measurement secure higher comparability between studies (Madsen, 2013). Therefore, we construct an ordinal variable, which equals 0 if the company is not internationalize. It equals 1 if the firm is internationalized but does not meet any of the above mentioned characteristics for accelerated internationalization. It equals 2 , if the firm meets one characteristic. It equals 3 , if the firm meets two characteristics. Finally, it equals 4 , if the firm meets the three characteristics of accelerated internationalization. Considering that the dependent variable is on an ordinal scale, an ordered logistic regression was used (Greene, 2011).

\subsubsection{Independent variables}

This study includes four set of main independent variables: effectual networking, strength of the network ties, institutional voids and location. Following similar studies, we measure effectual networking based on the pre-commitment sub-dimension (Galkina \& Chetty, 2015) and Chandler et al.'s (2011) measurement approach. However, because Chandler et al. (2011) had found only marginal reliability (i.e., Cronbach's $\alpha$ of 0.62 ) in their pre-commitment subscale, our measure departs from it by adhering more closely to the original understanding of the effectual networking concept. In particular, Prashantham et al. (2019, pp 6) state that the corresponding effectual networking actions of pre-commitment is "forming partnerships with people and organizations willing to make a genuine commitment to jointly co-creating the future - product, firm, market". Similar, Frese, et al. (2019, pp 7) "observed precommitments in the form of early customer involvement in product development, 
including customer obligations to purchase the cooperatively developed product". Finally, Read et al. (2009, pp 2) suggest that effectual firms "co-create it through commitments with a network of partner, investor, and customer stakeholders. Effectuation also specifies three types of intangible resources with which the effectuator co-creates new ends (i.e., new firms, products/services, and markets) through an iterative and interactive process of stakeholder acquisition". Therefore, our measure of effectual networking is related with the co-creation process with customers. Specifically, the survey asks respondents whether any of the new or significantly improved products or services were introduced because of specific customer requests or direct demands? We use a dummy variable that takes the value of " 1 " if a firm has shown effectual networking and " 0 " if otherwise.

Following Söderqvist and Chetty (2013), we measure the strength of the network ties by identifying whether the firm has active participation and commitment (strong ties) or not (weak ties). Industry. Specifically, Granovetter (1973, pp1362) explains that "Stronger ties involve larger time commitment" while "weak ties involve short time commitment". Therefore, we use the following question: Does the senior management of this establishment (or the firm to which it belongs) regularly spend time interacting with the industry organization or business association? Based on the answer we construct a dummy variable, where $1=$ strong domestic ties and $0=$ weak domestic ties.

Following Stephan, et al., (2015), this study uses the 2017 Worldwide Governance Indicators to measure institutional voids. Even though Argentina, Colombia and Peru suffer from institutional voids (Pawęta, 2016), Argentina has tended to experience higher institutional voids, while Colombia and Peru have lower institutional voids (Carneiro \& Brenes, 2014). It means that the selected countries have different business environments, thus contributing to the research purpose. Therefore, Argentina, which has the highest institutional voids (ranked 60) was coded with 0 , while Colombia and Peru which have lower institutional voids (ranked 51 and 49 respectively) were coded with 1 . 
Finally, to capture the location of the firm, similar to Agnoletti, et al., (2015) and ESPON (2007), we create an ordinal variable that combines the size of the city (population) and whether or not the firm is in the main business city of the country. We coded 2 for firms that are located in first-tier city. We coded 1 for firms that are located in second-tier city. Finally, we coded 0 for firms that are located in small cities (population under 1 million people) which are called rural cities (Chevassus-Lozza \& Galliano, 2003).

\subsubsection{Control variables}

We controlled for the firm's size, foreign ownership, trade regulations, government contract, informal competition and sector. Firm size (measured by the number of employees) is an important control variable because the size of the firm might determine its resources (Torkkeli et al., 2019). Size might also moderated the impact of strong domestic ties on the likelihood of accelerated internationalization (Cardoza, et al., 2016; Galkina \& Chetty, 2015). Previous studies suggest that foreign-owned firms are more likely to internationalize because they might have international networks and internationalization knowledge (Deng \& Zhang, 2018; Filatotchev, et al, 2008; Yi, et al., 2013). Consequently, we controlled if the firm was foreign-owned. We also controlled if trade regulations have hindered the firm's current operations, which is important because it can influence the firm's strategy and its internationalization process (Wilson, et al., 2005). Likewise, access to government contracts seems to accelerate the internationalization process (Cardoza, , et al., 2016). Moreover, informal competition might push firms to seek opportunities in foreign markets (Krammer et al., 2018). Finally, we control the sector to which the firm belongs since it may play an important role in the internationalization process of the firm (Amorós, et al., 2016).

\subsection{Results and discussion}

The correlation matrix allows the identification of any potential problems of multicollinearity that interfere with the analysis. Table 11 shows the means, the standard 
deviations, the correlation coefficients and the VIF scores. As can be seen, multicollinearity is not a problem because none of the correlations appear to be large (Hair, et al., 2010).

Table 12, shows the probability estimations of the ordinal logistic regression model. The aim of this analysis was to establish associations between location, institutional voids, effectual networking and network strength on the accelerated internationalization of Latin American SMEs. To test the hypotheses, the logistic regression was run in three steps as seen in Table 12. First, Model 1 shows the fundamental model, which only includes the control variables. Model 2 includes the fourth main independent variables of the study to test hypotheses 1, 2, 3 and 5 . Model 3 show the results of the interaction effects included in hypotheses 4, 6 and 7. The chi-square test of Model 3 is significant $(p<.01)$ and the Nagelkerke pseudo $\mathrm{R}^{2}$ shows that the model improves with the independent variables and moderator variables. To interpret our results, we used the odds ratio, which shows the probability of an event occurring (Amorós et al., 2016; Ciravegna, et al., 2014; Ellis, 2011).

Table 11. Descriptive statistics and Correlation Matrix

\begin{tabular}{|c|c|c|c|c|c|c|c|c|c|c|c|c|c|c|}
\hline & Mean & S.D. & VIF & 1 & 2 & 3 & 4 & 5 & 6 & 7 & 8 & 9 & 10 & 11 \\
\hline $\begin{array}{l}\text { 1. Institutional } \\
\text { voids }\end{array}$ & 1 & 0,817 & 1,129 & 1 & & & & & & & & & & \\
\hline 2. City-tier & 1,39 & 0,637 & 1,076 & $0,227^{* *}$ & 1 & & & & & & & & & \\
\hline 3. Sector & 2,21 & 0,768 & 1,074 & $0,099^{* *}$ & $0,041^{*}$ & 1 & & & & & & & & \\
\hline 4. Size & 1,79 & 0,815 & 1,246 & $0,-\bar{c}$ & 0,022 & $0,114^{* *}$ & 1 & & & & & & & \\
\hline $\begin{array}{l}\text { 5. Foreign } \\
\text { ownership }\end{array}$ & 0,08 & 0,268 & 1,121 & $0,081^{* *}$ & $0,101^{* * *}$ & $-0,015$ & $0,231^{* *}$ & 1 & & & & & & \\
\hline $\begin{array}{l}6 . \\
\text { Internationally } \\
\text { recognized } \\
\text { quality } \\
\text { certification } \\
\end{array}$ & 0,22 & 0,414 & 1,268 & $-0,018$ & $0,046^{*}$ & $0,130^{* *}$ & $0,373^{* *}$ & $0,218^{* * *}$ & 1 & & & & & \\
\hline $\begin{array}{l}\text { 7. Trade } \\
\text { regulations }\end{array}$ & 0,4 & 0,49 & 1,094 & $\begin{array}{c}- \\
0,120^{* *}\end{array}$ & $0,055^{* * *}$ & 0,031 & $0,181^{* *}$ & $0,132^{* * *}$ & $0,177^{* *}$ & 1 & & & & \\
\hline $\begin{array}{l}\text { 8. Informal } \\
\text { competition }\end{array}$ & 0,74 & 0,439 & 1,044 & 0,027 & $-0,026$ & $-0,028$ & $0,083^{* *}$ & $0, \overline{124^{* *}}$ & $0,150^{* *}$ & 0,016 & 1 & & & \\
\hline $\begin{array}{l}\text { 9. Effectual } \\
\text { networking }\end{array}$ & 0,41 & 0,492 & 1,047 & $0,133^{* *}$ & 0,02 & $-0,01$ & 0,035 & $0,041^{*}$ & $0,063^{* *}$ & $0,058^{* *}$ & $0,046^{*}$ & 1 & & \\
\hline $\begin{array}{l}10 . \\
\text { Government } \\
\text { contract }\end{array}$ & 0,18 & 0,387 & 1,054 & $0,090^{* *}$ & $0,040^{*}$ & $0,136^{* *}$ & 0,01 & $-0,002$ & $0,088^{* *}$ & $0,052^{* *}$ & $\begin{array}{c}- \\
0,016\end{array}$ & $0,121^{* *}$ & 1 & \\
\hline $\begin{array}{l}\text { 11. Strong } \\
\text { Domestic Ties }\end{array}$ & 0,32 & 0,466 & 1,101 & $\overline{-}^{-}$ & $-0,018$ & $\overline{-}^{*}$ & $0,232^{* *}$ & $0,129^{* *}$ & $0,220^{* *}$ & $0,076^{* *}$ & $\begin{array}{c}- \\
0,035\end{array}$ & $0,075^{* *}$ & 0,032 & 1 \\
\hline
\end{tabular}


${ }^{*}$ po.05, ${ }^{* *}$ po.01, ${ }^{* * *}$ po.001. Pearson's correlation, two-tailed significant.

In model 1, we find a significant positive association between the sector and the size of the firm on the accelerated internationalization. Our analysis shows that the primary sector proves to be very effective in increasing the odds of accelerating internationalization by a factor of 2.72. Similar to other studies (e.g. Amorós, et al., 2016), we found that, because exports of Latin American countries are mainly related to the primary sector, firms located in such exporting sectors are more likely to experience accelerated internationalization. This confirms that, unlike developed economies, in developing economies, accelerated internationalization is not necessarily linked to high-tech sectors (Rialp, et al., 2005). Regarding the size of the firm, we confirm that in general terms, bigger companies tend to reach accelerated internationalization and to a greater degree than smaller firm (Bernard, et al., 2007).

Similarly, the existence of an internationally recognized quality certification, government contracts and foreign ownership, increases the adds of accelerated internationalization. Quality certifications help firms from developing economies to develop domestic and international ties with other legitimate players and convince consumers of the quality of their products and services (Qi et al., 2011; Sui \& Baum, 2014). Likewise, access to government contracts positively affect firms' competitiveness and behavior, and therefore, promote international expansion (Cardoza, et al., 2016). Foreign-owned firms are also more likely to experience accelerated internationalization, which is in line with the literature (Deng \& Zhang, 2018; Krammer et al., 2018). It seems that the presence of foreign capital in the ownership of the firm, may provide access to international ties and internationalization knowledge (Deng \& Zhang, 2018; Yi et al., 2013).

Finally, we found that firms in which trade regulations and informal competition are not an obstacle to their operations have more probabilities to reach a accelerated internationalization. It seems that companies that are capable of overcoming trade regulations and informal competition, have a better managerial practices that help them to internationalize faster (Kahiya, 2013). 
Table 12. Estimates of ordinal logistic regression model

\begin{tabular}{|c|c|c|c|c|c|c|}
\hline & \multicolumn{2}{|c|}{ Model 1} & \multicolumn{2}{|c|}{ Model 2} & \multicolumn{2}{|c|}{ Model 3} \\
\hline & $\beta$ & $\begin{array}{c}\operatorname{Exp}( \\
\beta)\end{array}$ & $\beta$ & $\begin{array}{c}\operatorname{Exp}( \\
\beta)\end{array}$ & $\beta$ & $\begin{array}{c}\operatorname{Exp}( \\
\beta)\end{array}$ \\
\hline Size & $\underset{*}{0,399^{* *}}$ & 1,490 & $\underset{*}{0,349^{* *}}$ & 1,418 & $0,488^{\star \star *}$ & 1,629 \\
\hline Foreign_ownership & $1,01^{* * *}$ & 2,746 & $\underset{*}{0,719^{* *}}$ & 2,052 & $0,717^{* * *}$ & 2,048 \\
\hline $\begin{array}{l}\text { Internationally_recognized_quality_certi } \\
\text { fication }\end{array}$ & $\underset{*}{0,545^{* *}}$ & 1,725 & $\underset{*}{0,478^{* *}}$ & 1,613 & $0,486^{* * *}$ & 1,626 \\
\hline Trade_regulations & $\underset{*}{0,814^{* *}}$ & 2,257 & $\underset{*}{0,904^{* *}}$ & 2,469 & $0,909^{* * *}$ & 2,482 \\
\hline Informal_competition & $\underset{*}{0,308^{* *}}$ & 0,735 & $0,434^{* *}$ & 0,648 & $0,425^{\star \star *}$ & 0,654 \\
\hline Government_contract & $0,076^{*}$ & 0,927 & $0,292^{\star *}$ & 0,747 & $0,284^{* *}$ & 0,753 \\
\hline Primary_sector & $1,004^{* *}$ & 2,729 & $\underset{*}{0,999 * *}$ & 2,716 & $1,030^{\star * *}$ & 2,801 \\
\hline Secondary_sector & $\underset{*}{1,383^{* *}}$ & 3,987 & $\underset{*}{1,328^{* *}}$ & 3,773 & $1,346^{\star * *}$ & 3,842 \\
\hline Effectual_networking & & & $0,374^{* *}$ & 1,454 & $0,809^{* * *}$ & 2,246 \\
\hline Strong_Domestic_Ties & & & $\underset{*}{0,626^{* *}}$ & 1,870 & $1,662^{* * *}$ & 5,270 \\
\hline Institutional_voids & & & $\underset{*}{0,521^{* *}}$ & 1,684 & $0,703^{\star \star *}$ & 2,020 \\
\hline First-tier_city & & & $-0,232$ & 0,793 & $\stackrel{-}{0,757^{* *}}$ & 0,579 \\
\hline Second-tier_city & & & $\underset{*}{-}{ }^{-}$ & 0,704 & $\frac{-}{0,489^{* * *}}$ & 0,613 \\
\hline Mod_Effectuation_Institutional_voids & & & & & $0,388^{-}$ & 0,678 \\
\hline Mod_Strong_first_tier_cities & & & & & $-0,28^{\star}$ & 0,756 \\
\hline Mod_Strong_Size & & & & & $0,293^{-}$ & 0,746 \\
\hline Nagelkerke & 21 & & 26 & & $26^{\circ}$ & \\
\hline Chi2 & 1.0 & & 5.7 & & 5.72 & \\
\hline $\mathrm{n}$ total & 2.9 & & 2.9 & & 2.98 & \\
\hline
\end{tabular}

Significance at ${ }^{*} p<0.10 ;{ }^{* *} p<0.05 ;{ }^{* * *} p<0.01$

Contrary to our prediction, the result of model 2 shows that first- and second-tier cities are significantly negative, suggesting that rural cities, as opposed to urban cities, accelerated the firm's internationalization process. This is probably due to the following reasons. First, given the importance of the primary sector on performing accelerated internationalization, and that this sector is mainly located in rural areas, 
it is reasonable that rural areas provide the benefits from agglomeration economies. Research on this topic has found that both location and sectoral contiguity are important factors for agglomeration economies (Combes, 2000; Meliciani \& Savona, 2015). Indeed, in countries with exporting sectors located in rural areas, specialized infrastructure, inter-firm knowledge exchange and development of innovation capability are also found there (Hervas-Oliver, et al., 2018; Westhead, et al, 2004). This finding might complement why Amorós et al., (2016) found that first- and second-tier cities agglomeration is not a significant variable for early internationalization. Second, first- and second-tier cities might act as an inhibitor to accelerated internationalization. For instance, Fillis (2002) found that one of the main reasons for not exporting is having satisfactory performance in the local market. Similarly, Julian and Ahmed (2005) and more recently, Kyvik et al., (2013) suggest that the demand of big cities negatively affects the orientation of the firm towards the discovery of international opportunities.

Model 2 also support hypothesis 2. The coefficients for institutional voids are significantly positive. This result suggests that institutional voids positively influence the acceleration of the internationalization process. This finding is in line with the institutional escapism view. This view suggests that SMEs from developing economies internationalize to escape institutional voids (Doh, et al., 2017; Xiao, et al., 2017). The reason is that firms in such a context, develop advantages from their exposure to uncertainty (Khanna \& Palepu, 2010), becoming flexible, adaptable and resilient (Ciravegna \& Brenes, 2016), and thus achieve accelerated internationalization easier (Cuervo-Cazurra, et al., 2018).

The results of model 2 also confirm that firms that use effectual networks have a higher likelihood of accelerated internationalization. In line with recent studies (eg. Kalinic et al., 2014; Prashantham et al., 2019), effectual networking seems to be appropriate in a context of uncertainty. Being open to a variety of new potential partners, and selecting those who are willing to co-create opportunities, such as new products, increase the odds for accelerated internationalization. Thus, hypothesis 3 is accepted. Finally, we found evidence to support hypothesis 5. As expected, it 
seems that strong domestic ties are more relevant than weak domestic ties in the early phases of a firm's accelerated internationalization process (Gulati, et al., 2011; Söderqvist \& Chetty, 2013). The close proximity of strong domestic ties motivates knowledge sharing and resource exchanging, and therefore, accelerated internationalization (Westhead et al., 2004).

Model 3 shows that firms located in a context of significant institutional voids which also have effectual networking, have a higher likelihood of accelerated internationalization. Effectual networking is appropriate in context of significant institutional voids because it help firm to cope with uncertainty. In other words, it seems that effectual networking decreases uncertainty by co-creating new opportunities and transforming accessible means into new goals (Kerr \& Coviello, 2019b; Kubberød, et al., 2019). Thus, hypothesis 4 is accepted. Similarly, we found that the size of the firm moderated the impact of strong domestic ties on the likelihood of accelerated internationalization. Smaller firms that rely on strong ties have higher probabilities to achieved accelerated internationalization. One possible explanation is that weak domestic ties are costly to build and maintain. Consequently, smaller firms rely more in strong domestic ties than in weak domestic ties (Agndal, et al., 2008). Moreover, by engaging in strong domestic ties, smaller firms can overcome the uncertainty engendered by institutional voids, can take advantages of the agglomeration effects and develop co-creation activities with their partners.

Results of model 3 also shows that firms that have strong domestic ties and are located in rural cities have a higher likelihood of accelerated internationalization. In other words, it seems that rural cities facilitate access to nearby resources and ease the creation of strong network ties. In turn, these strong domestic networks allow knowledge sharing and resource exchanging. This finding confirms the importance of the primary sector which is mainly located in rural areas. Consequently, firms located in rural cities that have strong domestic ties, enhance the degree of accelerated internationalization. 
Figure 12. Conceptual model of accelerated internationalization

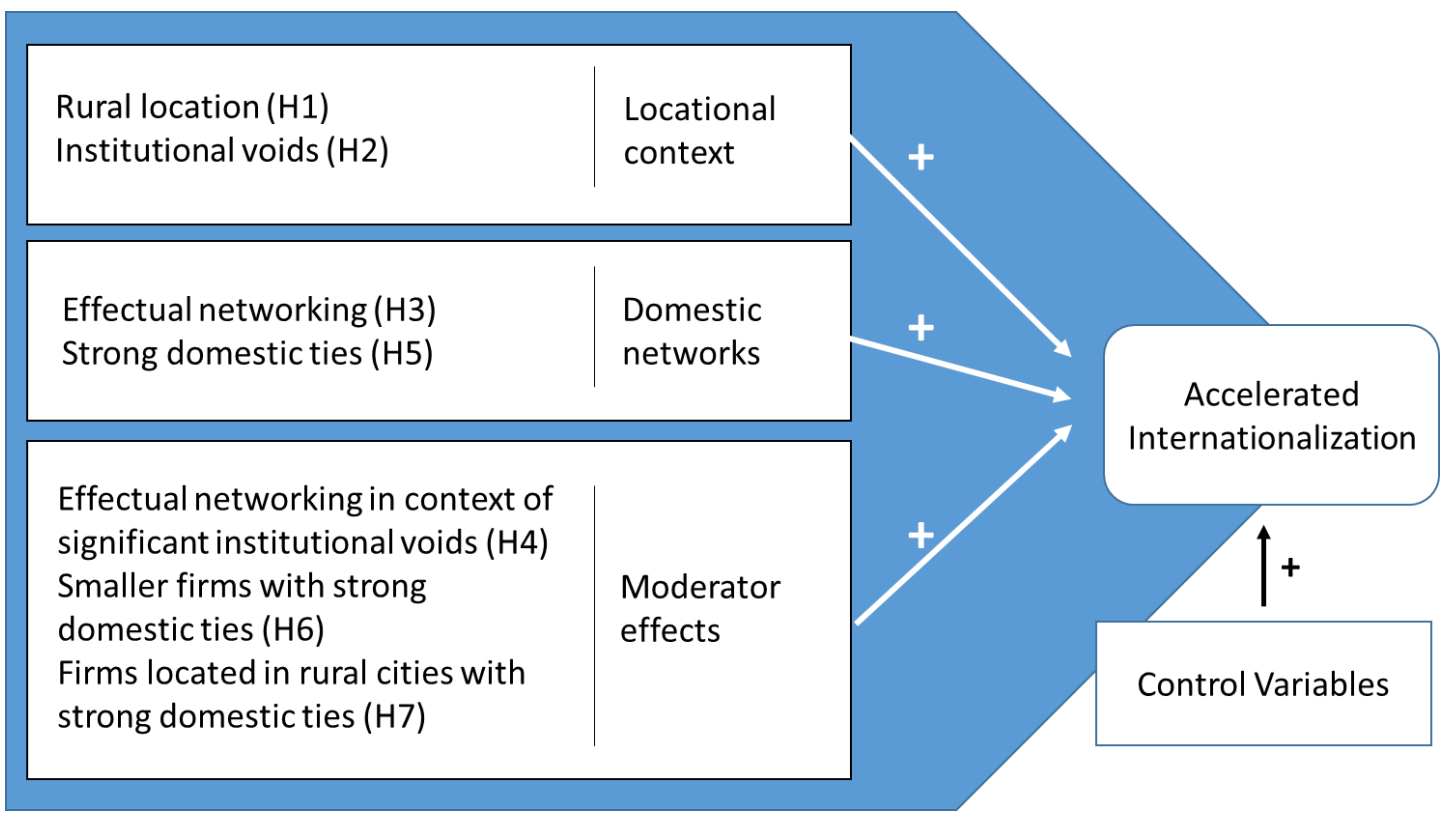

Source. Prepared by the author

Summing up, Fig. 12 presents the conceptual model and the relationship between locational context, domestic networks, and the moderating effects of location, institutional voids, effectual networking and domestic network strength. The first group of hypotheses analyses the influence of the locational context on the accelerated internationalization. This group suggests that rural location and institutional voids, increase the probabilities to reach accelerated internationalization. The second group of hypotheses argues that firms use effectual networking and strong domestic ties to achieve accelerated internationalization. It also shows the importance of domestic networks in this process. Finally, the third group of hypothesis show that effectual networking in context of significant institutional voids, increases the odds for accelerated internationalization. Likewise, smaller firms that have strong domestic ties have a greater likelihood of accelerated internationalization. Finally, firms that have strong domestic ties and are also located in rural cities have a higher likelihood of accelerated internationalization. 


\subsection{Conclusions}

From a theoretical standpoint, our study extends the literature by clarifying the micromechanisms that connect the impact of location, institutional voids, effectual networking and domestic network strength on the accelerated internationalization of Latin American SMEs. Although some research has taken important first steps to understand the individual impact of location (cf. Chevassus-Lozza \& Galliano, 2003), institutional voids (cf. Cardoza et al., 2016; Cuervo-Cazurra, et al,, 2018), effectual networking (cf. Kalinic, et al., 2014; Prashantham, et al., 2019), and network strength (cf. Srivastava, et al., 2018) on the accelerated internationalization of firms, no studies have investigated the combined effect of these factors. In response, we have analyzed how first-tier cities, second-tier cities and rural cities, level of country institutional voids, effectual networking and strong (weak) domestic ties contribute to a higher likelihood of accelerated internationalization and the moderator effect of interaction between location, institutional voids and effectual networking and network strength.

Our research, therefore, responds to recent calls to incorporate effectuation research into institutional voids (Read, et al., 2016; Reuber, et al., 2016), the influence of effectual networking on accelerated internationalization (Prashantham, et al., 2019), the impact of location on accelerated internationalization (Bianchi \& Wickramasekera, 2016; Torkkeli et al., 2019) and more studies on Latin American SMEs (Torkkeli \& Fuerst, 2018). Our study reveals that rural cities, as opposed to first- and second-tier cities, have characterized firms' accelerated internationalization processes. Because Latin American exports are mainly related to the primary sector, firms located in such rural exporting sectors, are more likely to experience accelerated internationalization (Amorós, et al., 2016). It also seems that the demand of first- and second-tier cities might create an inhibitory effect (Julian \& Ahmed, 2005; Kyvik, et al., 2013).

In addition, our findings enhance our understanding of how institutional voids influence the acceleration of the internationalization process. This problematic context, may push firms to develop advantages from their exposure to uncertainty, 
becoming flexible, adaptable and resilient (Ciravegna \& Brenes, 2016; CuervoCazurra, et al., 2018; Khanna \& Palepu, 2010). These advantages help firms to escape institutional voids by entering into foreign markets (Doh, et al., 2017; Xiao, et al., 2017). Therefore, policy makers and managers need to consider the firm' location decision, because the setting of the firm might determine its internationalization process.

We find that firms that use effectual networks have a higher likelihood of accelerated internationalization. We also find that effectual networking seems to be appropriate in a context of significant institutional voids (Kalinic et al., 2014). It happens because firms that are open to a variety of new potential partners, and work with the ones that are willing to co-create opportunities, have a better chance of reducing uncertainty and consequently, achieve accelerated internationalization (Prashantham et al., 2019). From a managerial point of view, this means that firms should collaborate with their partners, with particular emphasis on their customers, to co-create opportunities, such as new products.

The results show that firms that have strong domestic ties have a higher likelihood of accelerated internationalization. When testing the interaction effect between the strength of the domestic tie with the size of the firm and its location, we found that the combined effect of strong domestic ties with these variables significantly accelerated the internationalization process. This significant relationship indicates that smaller firms use the trust atmosphere of strong domestic ties to overcome their resource constraint. It also shows that strong domestic ties may favor approachability to the agglomeration effects of rural cities, where firms of the primary sector is located (Berrou \& Combarnous, 2012). Finally, this significant relationship demonstrates that strong domestic ties motivate firms to share valuable information and resources, promoting co-creation activities which in turn support accelerated internationalization (Kalinic, et al., 2014; Prashantham, et al., 2019).

Finally, consistent with the literature on international entrepreneurship (eg. Cardoza, et al., 2016; Deng \& Zhang, 2018; Krammer et al., 2018) we found that size, foreign ownership, having internationally recognized quality certification, not been affected 
by trade regulations and informal competition, access to government contracts and sector increase the odds of reaching accelerated internationalization. Our findings encourage firms to strategically harness foreign capital to gain access to international ties and internationalization knowledge. In addition, our findings encourage policymakers to promote the access of SMEs to government contracts and international quality certifications.

Our study that may lead to future research avenues. For one, since this research is based on a large set of cross-sectional data, longitudinal studies would further enhance this research. For example, by analyzing how changes in the level of institutional voids affect the networking behavior of the firm. Second, our study includes data from three Latin American countries. The research of SMEs in a different context of institutional voids may try to extrapolate the findings of this research to other national settings. In addition, and due to the available data from the World Bank's Enterprise Surveys (ES) database, our measurement of effectual networking, measured by the co-creation process with customers, did not capture the full complexity of the concept. We did not capture the co-creation process with other partners such as investors, or suppliers. We leave these, however, to future research. Finally, future research can analyze how different behavioral norms or cultural differences (collective and societal) affect the accelerated internationalization of the firm. 


\section{Chapter five - General discussion of the research results}

The bibliometric analysis show the first influential articles that used the effectuation theory to analyse the internationalization of born global firms were the articles of Andersson (2011) and Harms and Schiele (2012). Both articles affirm that effectuation decision-making logic and networks explain the accelerated internationalization of born global firms. Since the publication of these articles, the number of publications per year, as well as the number of citations has grown. Reflecting the importance that this field of research has acquired and the efforts of the academic community to further it and develop it. The bibliometric analysis also show that this research field is structured into five areas. Those areas are: 1) The decision-making process of entrepreneurs during the internationalisation of the company; 2) The development of international entrepreneurship based on the theory of effectuation; 3) The analysis of entrepreneurial marketing using the theory of effectuation; 4) The impact of effectuation logic on knowledge acquisition, international opportunity identification and network creation; and 5) The impact of effectuation logic on the growth and survival of SMEs in international markets.

The bibliometric analysis also helped to identify literature gaps and research questions, which were addressed in this doctoral dissertation. For instance, regarding the first area, Chetty et al. (2015) found that firms that use effectuation logic, rely on their foreign networks and suggest for future research directions to include a qualitative study using other countries to test this finding. Similarly, Kalinic, et al. (2014) found that firms that change causation logic to effectuation logic can speed their internationalization. They also call for studies in different countries. Moreover, Nummela et al. (2014) argue that firms can internationalise using causation or effectuation logic. Therefore, further studies should contribute to understand why decision-making logic may change. Finally, Laine and Galkina (2017) propose that institutional voids might boosts effectuation instead of causation.

Finally, the bibliometric analysis revels that this research field is in a nascent stage. 
An additional literature review allow to identify mixed and contrary results among studies about the individual effect of domestic networks strength, decision-making logic and institutional voids on accelerated internationalisation. As explained before, a possible explanation for the discrepancies may be that accelerated internationalization is a complex phenomenon that should be studied by identifying the complex relations among variables, instead of individual relations (Bell, Filatotchev, \& Aguilera, 2014; Chetty, Johanson, \& Martín, 2014; Woodside, 2013).

Given these research gaps, and the discrepancies among researchers, the purpose of the third chapter was to combines theoretically relevant antecedents to explore when and under what circumstances the internationalization process of SMEs with institutional voids is accelerated. The result from the fuzzy-set qualitative comparative analysis of the 33 contrarian cases of micro and small-enterprises reveal that overall, accelerated internationalization is fostered by the strength of the domestic relationship with a combination of the decision-making logic. The results indicate that in most cases, weak domestic ties and effectuation logic behaviour lead to accelerated internationalization of SMEs with fewer resource constraints. In contrast, strong domestic ties and causation behaviour lead to accelerated internationalization of SMEs with greater resource constraints. These paths were found in Colombian and in Peru cases.

Results reveal that resource-constrained SMEs that do not have internal barriers can take advantage of their weak domestic connections in order to identify foreign opportunities using effectuation logic. It contrast, strong domestic ties combined with causation logic accelerate internationalization. It seems that SMEs that rely on strong domestic networks tend to use only causation logic to overcome their internal barriers to export. The difference between the accelerating path that should follow SMEs might be explained for by difference in the capabilities of the SMEs. The resources constraints and internal barriers of the firm can lead to a different type of network strength and decision-making logic. Due to the lack of resources, there are lower chances that SMEs with greater resource constraints are able to consolidated weak domestic ties. Therefore, they develop strong domestic ties. In opposite 
direction, SMEs with fewer resource constraints can use their resources to create, manage, and sustain weak domestic ties to access to novel information and identify international opportunities. Moreover, SMEs with greater resource constraints use causation as a mean to reduce risk. In contrast, SMEs with fewer resource constraints use effectuation logic to overcome the uncertainty instead of avoiding risk. This finding contribute to the clarification of why decision-making logic may change. Finally, thanks to the fsQCA, this chapter shows a dynamic perspective of the complex relations that can explain the accelerated internationalization of SMEs located in Latin America.

As mentioned, the difference on the resource constraints of the firm helps to explain the combination of factors that lead accelerated internationalization of SMEs located in context with institutional voids. However, there was still need for a better understanding about the discrepancy on the impact of the institutional voids (Laine \& Galkina, 2017). Moreover, even though networks are a central concept in the effectuation theory, there is scant evidence about the impact of effectual networking on accelerated internationalization (Prashantham, et al., 2019). Consequently, the emphasis of the fourth chapter was to establish associations between location, institutional voids, effectual networking and network strength on the accelerated internationalization of Latin American SMEs. Therefore, data from Argentina was included, to be able to compare the impact of the different levels of institutional voids that Colombia, Peru and Argentina have. This variable was complemented with the analysis of the firm's location (first- and second-tier cities vs rural cities). It also include a variable that measure if the SMEs implement or not effectual networking, and the type of domestic network strength (weak or strong). Moreover, the following control variables were included: firm's size, foreign ownership, trade regulations, government contract, informal competition and sector.

The result of the ordered logistic regression shows that that institutional voids increase the odds for accelerated internationalization. This finding is in line with the institutional escapism view which suggests that SMEs from developing economies internationalize to escape from this voids (Doh, et al., 2017; Xiao, et al., 2017). 
Result also indicate that firms that use effectual networks have a higher likelihood of accelerated internationalization. Moreover, SMEs that have strong domestic ties have better chances to reach accelerated internationalization.

In relation with the firm's location, results shows that rural cities accelerated the firm's internationalization process. Latin American exports are mainly related to the primary sector which is mostly located in rural areas, therefore, it is reasonable that rural areas provide the benefits from agglomeration economies (Amorós, et al., 2016). When testing the interaction effect between the strength of the local tie with the size of the firm and its location, we found that the combined effect of strong local ties with these variables significantly accelerated the internationalization process. This significant relationship indicates that smaller firms use the trust atmosphere of strong local ties to overcome their resource constraint. It also shows that strong local ties may favor approachability to the agglomeration effects of rural cities, where firms of the primary sector is located (Berrou \& Combarnous, 2012).

Finally, consistent with the literature on international entrepreneurship (eg. Cardoza, et al., 2016; Deng \& Zhang, 2018; Krammer, et al. 2018) it was found that size, foreign ownership, having internationally recognized quality certification, access to government contracts, ot been affected by trade regulations and informal competition increase the odds of reaching accelerated internationalization.

Although the fsQCA and the ordinal logistic regression have different methodological aims and data, results have the following similarities. First, effectuation logic and effectual networking help firms to overcome the uncertainty created by the institutional voids. The results from the fsQCA show that firms implement effectuation logic to cope with institutional voids. Likewise, the result from the ordinal regression evidence that effectual networking in context of significant institutional voids, enhance the probabilities of achieve accelerated internationalization.

Second, both studies also reveals that strong domestic ties are relevant for reaching accelerated internationalization, especially for smaller firms. The result from the fsQCA suggest that the atmosphere of trust embedded in domestic strong networks 
help firms to overcome their internal barriers to export. Similarly, the result from the ordinal logistic regression propose that strong domestic ties potentiate the benefits of effectual networking, the agglomeration effects of rural cities and lessen the institutional voids. Moreover, it seems that strong domestic networks have a greater positive impact on SMEs with greater resource constraints. In the integrative model for accelerated internationalization (chapter 3), the second path to achieved accelerated internationalization was identified as a suitable route for microenterprises. Similarly, result of the ordinal regression model shows that smaller firms that have strong domestic ties have more probabilities to reach accelerated internationalization.

Finally, both studies identified the absence of external barriers as a factor that explain the accelerated internationalization of SMEs in Latin America. In the first study, absence of external barriers is a characteristic of the two internationalization paths. Alike, in the second study, firms in which trade regulations are not an obstacle have greater probabilities to accelerated internationalization. 


\section{Chapter six - Conclusion}

This doctoral thesis identify the complex relations and micro-mechanisms that connect the impact institutional voids, effectuation and networks strength on the accelerated internationalization of SMEs from Latin America. For this purpose, three different research methodologies were performed. First, a bibliometric analysis was implemented to have a better understanding about structure and key trends of the theory of effectuation and the internationalization. The bibliometric analysis was based on 30 articles collected from the Web of Science database, and analyze using Bibexcel, VOSviewer, Pajek and Tree of Science. To test the robustness of the results, an additional analysis of 25 articles collected from Scopus database was performed. The analysis show that the conceptual and theoretical basis of this research field is based on the theory of effectuation, born global model, the Uppsala model, international entrepreneurship and theory creation based on case studies. It also display that this research field is structured into the following five areas: Decision-making process; international entrepreneurship; marketing, knowledge acquisition, international opportunity identification and network creation; and growth and survival of SMEs in international markets. Finally, the bibliometric analysis revels that the explanation of internationalization using the theory of effectuation is in a nascent stage that need further advances.

The second research methodology was a fuzzy-set qualitative comparative analysis (fsQCA). The data was obtain through face to face interviews. It contains 33 contrarian cases from Colombia and Peru. The analyzed variables were domestic networks relationships (weak or strong domestic ties), decision-making logic (effectuation or causation), barriers to trade (internal or external), export promotion programs (beneficiary or non-beneficiary) and size of the company (micro or small enterprises). Findings show that the combination of weak domestic ties and effectuation logic accelerated the internationalization of SMEs with fewer resource constraints. In contrast, strong domestic ties and causation behavior lead to accelerated internationalization of SMEs with greater resource constraints. 
The primary contribution to the literature of this study relates to the identification of the causal conditions that are the most promising for explaining accelerated internationalization SMEs from context with institutional voids. By doing this, it was provide empirical evidence to contribute to clarify the mixed results regarding the impact of strong and weak domestic ties and decision-making logic in the accelerated internationalization of SMEs (Casillas \& Acedo, 2013; Coviello, 2015; Madsen, 2013). Second, the results of this study contribute to the literature by expanding the scant research on domestic networks and cases with institutional voids contexts (Haddoud, Jones, \& Newbery, 2017; Knight \& Liesch, 2016; Prashantham \& Birkinshaw, 2015). Finally, the study provides a novel approach that allows identifying complex relations of cases with asymmetric relationships (Chetty et al., 2014).

The third research methodology was an ordinal logistic regression was develop on data about effectual networking (presence or absence); domestic networks relationships (weak or strong ties); size of the company, level of institutional voids; sector (primary, secondary or tertiary); location (first- and second-tier or rural cities); foreign ownership (presence or absence); Internationally recognized quality certification (presence or absence); trade regulations (presence or absence); government contract (presence or absence); and informal competition (obstacle or not). The data from Argentina, Colombia and Peru was obtain from the World Bank's Enterprise Surveys.

The aim of this study was to examine the micro-mechanisms that connect these variables on the accelerated internationalization of Latin American SMEs, and the moderator effect of network strength. Synthesizing the findings, effectual networking, strong domestic ties, significant institutional voids, rural cities, informal competition, foreign ownership, informal competition, internationally recognized quality certification, and the fact that trade regulations are not an obstacle, increases the probability of reaching accelerated internationalization. Results also show that combined effect of strong local ties with size of the firm and its rural location significantly accelerated the internationalization process. 
The findings of this study mainly contribute by identifying micro-mechanisms behind the accelerated internationalization process of SMEs located in Latin American countries, which has received limited attention in previous research. Therefore, our research deepened discussions about effectual networking, institutional voids and the impact of location on accelerated internationalization (Bianchi \& Wickramasekera, 2016; Prashantham et al., 2019; Read, et al., 2016; Reuber, et al., 2016; Torkkeli, et al., 2019). 


\section{References}

Adomako, S., Amankwah-Amoah, J., Dankwah, G. O., Danso, A., \& Donbesuur, F. (2019). Institutional voids, international learning effort and internationalization of emerging market new ventures. Journal of International Management, In press. https://doi.org/10.1016/j.intman.2019.04.001

Adriaanse, L.S. and Rensleigh, C. (2013) 'Web of science, Scopus and Google Scholar a content comprehensiveness comparison', Electronic Library, Vol. 31, No. 6, pp.727-744. Available online at: http://doi.org/10.1108/EL-12-2011-0174

Agndal, H., Chetty, S., \& Wilson, H. (2008). Social capital dynamics and foreign market entry. International Business Review, 17(6), 663-675. https://doi.org/10.1016/j.ibusrev.2008.09.006

Agnoletti, C., Bocci, C., lommi, S., Lattarulo, P., \& Marinari, D. (2015). First- and Second-Tier Cities in Regional Agglomeration Models. European Planning Studies, 23(6), 1146-1168. https://doi.org/10.1080/09654313.2014.905006

Ahi, A., Baronchelli, G., Kuivalainen, O. and Piantoni, M. (2017) 'International market entry: how do small and medium-sized enterprises make decisions?', Journal of International Marketing, Vol. 25, No. 1, pp.1-21.

Amorós, J. E., Basco, R., \& Romaní, G. (2016). Determinants of early internationalization of new firms: the case of Chile. International Entrepreneurship and Management Journal, 12(1), 283-307. https://doi.org/10.1007/s11365-014-0343-2

Andersen, O. (1993) 'On the internationalization process of firms: a critical analysis', Journal of International Business Studies, Vol. 24, No. 2, pp.209-231. Available online at: http://doi.org/10.1057/palgrave.jibs.8490230

Andersson, S. (2011). International entrepreneurship, born globals and the theory of effectuation. Journal of Small Business and Enterprise Development, 18(3), 627-643. https://doi.org/10.1108/14626001111155745

Arend, R. J., Sarooghi, H., \& Burkemper, A. (2015). Effectuation as ineffectual? Applying the 3E theory-assessment framework to a proposed new theory of entrepreneurship. Academy of Management Review, 40(4), 630-651. https://doi.org/10.5465/amr.2014.0455

Asheim, B. T., \& Gertler, M. S. (2005). The Geography of Innovation: Regional Innovation Systems. In J. Fagerberg, D. C. Mowery, \& R. R. Nelson (Eds.), The Oxford Handbook of Innovation (pp. 291-317). Oxford University Press.

Audretsch, D., \& Feldman, M. (2004). Knowledge spillovers and the geography of innovation. In A. KL \& I. MD (Eds.), Handbook of regional and urban economics (Vol. 4, pp. 2713-2739).

Aulakh, P. S., \& Kotabe, M. (2008). Institutional changes and organizational transformation in developing economies. Journal of International Management, 
14(3), 209-216. https://doi.org/10.1016/j.intman.2008.04.001

Autio, E. (2005). Creative tension: The significance of Ben Oviatt's and Patricia McDougall's article 'toward a theory of international new ventures. Journal of International Business Studies, 36(1), 9-19. https://doi.org/10.1057/palgrave.jibs.8400117

Autio, E., Sapienza, H. J., \& Almeida, J. G. (2000). Effects of age at entry, knowledge, intensity, and immutability on international growth. Academy of Management Journal, 43(5), 909. https://doi.org/10.2307/1556419

Baier-Fuentes, H., Merigó, J. M., Amorós, J. E., \& Gaviria-Marín, M. (2019). International entrepreneurship: a bibliometric overview. International Entrepreneurship and Management Journal, 15(2), 385-429. https://doi.org/10.1007/s11365-017-0487-y

Balland, P. A., Belso-Martínez, J. A., \& Morrison, A. (2016). The dynamics of technical and business knowledge networks in industrial clusters: Embeddedness, status, or proximity? Economic Geography, 92(1), 35-60. https://doi.org/10.1080/00130095.2015.1094370

Bell, R. G., Filatotchev, I., \& Aguilera, R. V. (2014). Corporate governance and investors' perceptions of foreign ipo value: An institutional perspective. Academy of Management Journal, 57(1), 301-320. https://doi.org/10.5465/amj.2011.0146

Belso-Martínez, J. A. (2006). Why are some Spanish manufacturing firms internationalizing rapidly? The role of business and institutional international networks. Entrepreneurship and Regional Development, 18(3), 207-226. https://doi.org/10.1080/08985620600565409

Bernard, A. B., Bradford Jensen, J., Redding, S. J., \& Schott, P. K. (2007). Firms in international trade. Journal of Economic Perspectives, 21(3), 105-130. https://doi.org/10.1257/jep.21.3.105

Berrou, J. P., \& Combarnous, F. (2012). The Personal Networks of Entrepreneurs in an Informal African Urban Economy: Does the "Strength of Ties" Matter? Review of Social Economy, 70(1), 1-30. https://doi.org/10.1080/00346764.2011.577347

Bianchi, C., \& Wickramasekera, R. (2016). Antecedents of SME export intensity in a Latin American Market. Journal of Business Research, 69(10), 4368-4376. https://doi.org/10.1016/j.jbusres.2016.02.041

Boehe, D. (2013). Collaborate at Home to Win Abroad: How Does Access to Local Network Resources Influence Export Behavior? Journal of Small Business Management, 51(2), 167-182. https://doi.org/10.1111/jsbm.12013

Brache, J., \& Felzensztein, C. (2019). Exporting firm's engagement with trade associations: Insights from Chile. International Business Review, 28(1), 25-35. https://doi.org/10.1016/j.ibusrev.2018.07.001 
Brewer, P. (2001). International market selection: developing a model from Australian case studies. International Business Review, 10(2), 155-174.

Brouthers, L. E., \& Nakos, G. (2005). The role of systematic international market selection on small firms' export performance. Journal of Small Business Management, 43(4), 363-381. https://doi.org/10.1111/j.1540627X.2005.00142.x

Calvo, B. G. A., Izquierdo, A., \& Talvi, E. (2006). American Economic Association Sudden Stops and Phoenix Miracles in Emerging Markets. The American Economic Review, 96(2), 405-410.

Cao, Q., Gedajlovic, E., \& Zhang, H. (2009). Unpacking Organizational Ambidexterity: Dimensions, Contingencies, and Synergistic Effects. Organization Science, 20(4), 781-796. https://doi.org/10.1287/orsc.1090.0426

Cardoza, G., Fornes, G., Farber, V., Gonzalez Duarte, R., \& Ruiz Gutierrez, J. (2016). Barriers and public policies affecting the international expansion of Latin American SMEs: Evidence from Brazil, Colombia, and Peru. Journal of Business Research, 69(6), 2030-2039. https://doi.org/10.1016/j.jbusres.2015.10.148

Carneiro, J., \& Brenes, E. R. (2014). Latin American firms competing in the global economy. Journal of Business Research, 67(5), 831-836. https://doi.org/10.1016/j.jbusres.2013.07.001

Casillas, J. C., \& Acedo, F. J. (2013). Speed in the Internationalization Process of the Firm. International Journal of Management Reviews, 15(1), 15-29. https://doi.org/10.1111/j.1468-2370.2012.00331.x

Cavusgil, S. T., \& Knight, G. A. (2009). Born Global Firms Georgia State University (First). USA: Business Expert Press.

Cesinger, B., Bouncken, R., Fredrich, V. and Kraus, S. (2014) 'The alchemy of family enterprises' internationalisation: dexterous movers or prodigal laggards?', European Journal of International Management, Vol. 8, No. 6, pp.671-696. Available online at: https://doi.org/10.1504/ejim.2014.064902

Chabowski, B.R., Samiee, S. and Hult, G.T.M. (2017) 'Cross-national research and international business: an interdisciplinary path', International Business Review, Vol. 26, No. 1, pp.89-101. Available online at: http://doi.org/10.1016/j.ibusrev.2016.05.008

Chandler, G. N., DeTienne, D. R., McKelvie, A., \& Mumford, T. V. (2011). Causation and effectuation processes: A validation study. Journal of Business Venturing, 26(3), 375-390. https://doi.org/10.1016/j.jbusvent.2009.10.006

Chandra, Y. (2017) 'A time-based process model of international entrepreneurial opportunity evaluation', Journal of International Business Studies, Vol. 48, No. 4, pp.423-451. Available online at: http://doi.org/10.1057/s41267-017-0068-x

Chandra, Y., Styles, C., \& Wilkinson, I. (2009). The recognition of first time 
international entrepreneurial opportunities. International Marketing Review, 26(1), 30-61. https://doi.org/10.1108/02651330910933195

Chandra, Y., Styles, C. and Wilkinson, I.F. (2015) 'Opportunity portfolio: moving beyond single opportunity explanations in international entrepreneurship research', Asia Pacific Journal of Management, Vol. 32, No. 1, pp.199-228. Available online at: http://doi.org/10.1007/s10490-014-9400-1

Chen, G. and Xiao, L. (2016) 'Selecting publication keywords for domain analysis in bibliometrics : a comparison of three methods', Journal of Informetrics, Vol. 10, No. 1, pp.212-223. Available online at: http://doi.org/10.1016/j.joi.2016.01.006

Chetty, S., \& Agndal, H. (2007). Social Capital and Its Influence on Changes in Internationalization Mode Among Small and Medium-Sized Enterprises. Journal of International Marketing, 15(1), 1-29.

Chetty, S., \& Blankenburg Holm, D. (2000). The Role of Business Networks in the Internationalisation of Manufacturing Firms: A Longitudinal Case Study. Advances in International Marketing, (4), 333-355.

Chetty, S., Johanson, M., \& Martín, M. O. (2014). Speed of internationalization: Conceptualization, measurement and validation. Journal of World Business, 49(4), 633-650. https://doi.org/10.1016/j.jwb.2013.12.014

Chetty, S., Ojala, A., \& Leppäaho, T. (2015). Effectuation and foreign market entry of entrepreneurial firms. European Journal of Marketing, 49(9/10), 1436-1459. https://doi.org/https:// doi.org/10.1108/EJM-11-2013-0630

Chevassus-Lozza, E., \& Galliano, D. (2003). Local spillovers, firm organization and export behaviour: Evidence from the French food industry. Regional Studies, 37(2), 147-158. https://doi.org/10.1080/0034340022000057505

Ciravegna, L., Lopez, L. E., \& Kundu, S. K. (2016). The internationalization of Latin American enterprises-Empirical and theoretical perspectives. Journal of Business Research, 69(6), 1957-1962. https://doi.org/10.1016/j.jbusres.2015.10.141

Ciravegna, L., Majano, S. B., \& Zhan, G. (2014). The inception of internationalization of small and medium enterprises: The role of activeness and networks. Journal of Business Research, 67, 1081-1089. https://doi.org/10.1016/j.jbusres.2013.06.002

Cobo, M. J., Martínez, M. A., Gutiérrez-Salcedo, M., Fujita, H., \& Herrera-Viedma, E. (2015). 25 years at Knowledge-Based Systems: A bibliometric analysis. Knowledge-Based Systems, $\quad 80, \quad 3-13$. https://doi.org/10.1016/j.knosys.2014.12.035

Combes, P. (2000). Economic Structure and Local Growth: Journal of Urban Economics, 47, 329-355. https://doi.org/10.1006/juec.1999.2143

Coviello, N. E. (2006). The network dynamics of international new ventures. Journal of International Business Studies, 37(37), 713-731. Retrieved from 
http://www.jstor.org

Coviello, N. E. (2015). Re-thinking research on born globals. Journal of International Business Studies, 46(1), 17-26. https://doi.org/10.1057/jibs.2014.59

Coviello, N. E., \& Cox, M. P. (2006). The resource dynamics of international new venture networks. Journal of International Entrepreneurship, 4(2-3), 113-132. https://doi.org/10.1007/s10843-007-0004-4

Coviello, N. E., \& Joseph, R. M. (2012). Creating Major Innovations with Customers: Insights from Small and Young Technology Firms. Journal of Marketing, 76(6), 87-104. https://doi.org/10.1509/jm.10.0418

Coviello, N.E. and Munro, H. (1997) 'Network relationships and the internationalization process of small software firms', International Business Review, Vol. 6, No. 4, pp.361-386.

Crick, D. and Crick, J. (2014) 'The internationalization strategies of rapidly internationalizing high-tech UK SMEs: planned and unplanned activities', European Business Review, Vol. 26, No. 5, pp.421-448. Available online at: https://doi.org/10.1108/JHOM-09-2016-0165

Crick, D. and Crick, J. (2016) 'An appreciative inquiry into the first export order', Qualitative Market Research: An International Journal, Vol. 19, No. 1, pp.84100.

Cuervo-Cazurra, A. (2012). Extending theory by analyzing developing country multinational companies: Solving the Goldilocks debate. Global Strategy Journal, 2(3), 153-167. https://doi.org/10.1111/j.2042-5805.2012.01039.x

Cuervo-Cazurra, A., Ciravegna, L., Melgarejo, M., \& Lopez, L. (2018). Home country uncertainty and the internationalization-performance relationship: Building an uncertainty management capability. Journal of World Business, 53(2), 209-221. https://doi.org/10.1016/j.jwb.2017.11.002

Cuervo-Cazurra, A., Luo, Y., Ramamurti, R., \& Ang, S. H. (2018). The Impact of the home country on internationalization. Journal of World Business, 53(5), 593604. https://doi.org/10.1016/j.jwb.2018.06.002

De Clercq, D., \& Bowen, H. P. (2008). Institutional context and effort the allocation of entrepreneurial. Journal of International Business Studies, 39(4), 747-768. https://doi.org/10.1057/palgnave.jibs.8400343

Deligianni, I., Voudouris, I. and Lioukas, S. (2017) 'Do effectuation processes shape the relationship between product diversification and performance in new ventures ?',Entrepreneurship: Theory and Practice, Vol. 41, No. 3, pp.1-29. Available online at: http://doi.org/10.1111/etap.12210

Deng, P., \& Zhang, S. (2018). Institutional quality and internationalization of emerging market firms: Focusing on Chinese SMEs. Journal of Business $\begin{array}{lll}\text { Research, 2018), 279-289. } & \text { 20vember }\end{array}$ https://doi.org/10.1016/j.jbusres.2018.07.014 
Dettmann, A., \& Brenner, T. (2010). Proximity Is a Social Process : a Conceptual Modification (Vol. 39).

Dimitratos, P., Amorós, J. E., Etchebarne, M. S., \& Felzensztein, C. (2014). Micromultinational or not? International entrepreneurship, networking and learning effects. Journal of Business Research, 67, 908-915. https://doi.org/10.1016/j.jbusres.2013.07.010

Ding, Y., Chowdhury, G. and Foo, S. (1999) 'Mapping the intellectual structure of information retrieval studies : an author co-citation analysis, 1987-1997', Journal of Information Science, Vol. 25, No. 1, pp.67-78.

Doh, J., Rodrigues, S., Saka-Helmhout, A., \& Makhija, M. (2017). International business responses to institutional voids. Journal of International Business Studies, 48(3), 293-307. https://doi.org/10.1057/s41267-017-0074-z

Durán-Sánchez, A., Del Río-Rama, M. de la C. and Álvarez-García, J. (2017) 'Bibliometric analysis of publications on wine tourism in the databases Scopus and WoS', European Research on Management and Business Economics, Vol. 23, No. 1, pp.8-15. Available online at: https://doi.org/10.1016/J.IEDEEN.2016.02.001

Duranton, G., \& Puga, D. (2001). Nursery cities: Urban diversity, process innovation, and the life cycle of products. American Economic Review, 91(5), 1454-1477. https://doi.org/10.1257/aer.91.5.1454

Dzikowski, P. (2018) 'A bibliometric analysis of born global firms', Journal of Business Research, Vol. 85(November 2016), pp.281-294. Available online at: http://doi.org/10.1016/j.jbusres.2017.12.054

Edmondson, A.C. and McManus, S.E. (2007) 'Methodological fit in management field research', Academy of Management Review, Vol. 32, No. 4, pp.11551179. Available online at: http://doi.org/10.5465/AMR.2007.26586086

Eisenhardt, K. M. (1989). Building Theories from Case Study Research. The Academy of Management Review, 14(4), 532-550.

Ellis, P. D. (2000). Social ties and foreign market entry. Journal of International Business Studies, 31(3), 443-469.

Ellis, P. D. (2011). Social ties and international entrepreneurship: Opportunities and constraints affecting firm internationalization. Journal of International Business Studies, 42(1), 99-127. https://doi.org/10.1057/jibs.2010.20

Ellis, P. D., \& Pecotich, A. (2001). Social Factors Influencing Export Initiation in Small and Medium-Sized Enterprises. Journal of Marketing Research, 38(1), 119130. https://doi.org/10.1509/jmkr.38.1.119.18825

ESPON. (2007). Study of urban function ESPON project 1.4.3. Final Report. Retrieved from https://www.espon.eu/sites/default/files/attachments/fr1.4.3_April2007-final.pdf 
Evers, N., Andersson, S. and Hannibal, M. (2012) 'Stakeholders and marketing capabilities in international new ventures: evidence from Ireland, Sweden and Denmark', Journal of International Marketing, Vol. 20, No. 4, pp.46-71. Available online at: http://doi.org/10.1509/jim.12.0077

Evers, N. and O'Gorman, C. (2011) 'Improvised internationalization in new ventures: the role of prior knowledge and networks', Entrepreneurship \& Regional Development, Vol. 23, No. 7/8,pp.549-574. Available online at: http://doi.org/10.1080/08985621003690299

Fernhaber, S. A., \& Li, D. (2013). International exposure through network relationships: Implications for new venture internationalization. Journal of Business Venturing, 28(2), 316-334. https://doi.org/10.1016/j.jbusvent.2012.05.002

Fiedler, A., Fath, B. P., \& Whittaker, D. H. (2016). Overcoming the liability of outsidership in institutional voids: Trust, emerging goals, and learning about opportunities. International Small Business Journal, 35(3), 1-23. https://doi.org/10.1177/0266242616662510

Filatotchev, I., Stephan, J., \& Jindra, B. (2008). Ownership structure, strategic controls and export intensity of foreign-invested firms in transition economies. Journal of International Business Studies, 39(7), 1133-1148. https://doi.org/10.1057/palgrave.jibs.8400404

Fillis, I. (2002). Barriers to internationalisation: An investigation of the craft microenterprise. European Journal of Marketing, 36(7/8), 912-927. https://doi.org/10.1108/03090560210430872

Fischer, E., \& Reuber, A. R. (2011). Social interaction via new social media: (How) can interactions on Twitter affect effectual thinking and behavior? Journal of Business Venturing, 26(1), 1-18. https://doi.org/10.1016/j.jbusvent.2010.09.002

Forsgren, M., Holm, U. and Johanson, J. (Eds) (2015) Knowledge, Networks and Power The Uppsala School of International Business, Palgrave Macmillan

Frechette, M. (2006). Rethinking Latin America: A new approach in US foreign policy. Harvard International Review, 28(2), 28-31.

Freeman, J., Styles, C., \& Lawley, M. (2012). Does firm location make a difference to the export performance of SMEs? International Marketing Review, 29(1), 88113. https://doi.org/10.1108/02651331211201552

Frese, T., Geiger, I., \& Dost, F. (2019). An empirical investigation of determinants of effectual and causal decision logics in online and high-tech start-up firms. Small Business Economics, 1(24), 1-24.

Fuerst, S. and Zettinig, P. (2015) 'Knowledge creation dynamics within the international new venture', European Business Review, Vol. 27, No. 2, pp.182- 
213. Available online at: http://doi.org/https://doi.org/10.1108/ EBR-03-20130036

Fuller-Love, N., Midmore, P., Thomas, D., \& Henley, A. (2006). Entrepreneurship and rural economic development: A scenario analysis approach. International Journal of Entrepreneurial Behaviour and Research, 12(5), 289-305. https://doi.org/10.1108/13552550610687655

Gabrielsson, P. and Gabrielsson, M. (2013) 'A dynamic model of growth phases and survival in international business-to-business new ventures: the moderating effect of decision-making logic', Industrial Marketing Management, Vol. 42, No. 8, pp.1357-1373. Available online at: http://doi.org/10.1016/j.indmarman.2013.07.011

Galkina, T., \& Chetty, S. (2015). Effectuation and Networking of Internationalizing SMEs. Management International Review, 55(5), 647-676. https://doi.org/10.1007/s11575-015-0251-x

Gil-Barragan, J. M., Belso-Martínez, J. A., \& Mas-Verdú, F. (2020a). Bibliometric analysis of the theory of effectuation and the internationalisation of small and medium-sized enterprises. European Journal of International Management, inpress. https://doi.org/10.1504/EJIM.2020.10026119

Gil-Barragan, J. M., Belso-Martínez, J. A., \& Mas-Verdú, F. (2020b). When do domestic networks cause accelerated internationalization under different decision-making logic? Evidence from weak institutional environment. European Business Review, 32(4), in-press. https://doi.org/10.1108/EBR-112018-0191

Goel, S., \& Karri, R. (2006). Entrepreneurs, effectual logic, and over-trust. Entrepreneurship Theory and Practice, 30(4), 477-493. https://doi.org/10.1111/j.1540-6520.2006.00131.x

Granovetter, M. S. (1973). The Strength of Weak Ties. American Journal of Sociology, 78(6 (May 1973)), 1360-1380.

Granovetter, M. S. (1985). Economic action and social structure: The problem of embeddedness. American Journal of Sociology, 91(3), 481-510. https://doi.org/10.1086/228311

Grant, R.M. (1996) 'Toward a knowledge-based theory of the firm', Strategic Management Journal, Vol. 17, pp.109-122.

Greene, W. H. (2011). Econometric Analysis (7th ed.). Pearson.

Gulati, R., Lavie, D., \& Madhavan, R. (2011). How do networks matter? The performance effects of interorganizational networks. Research in Organizational Behavior, 31, 207-224. https://doi.org/10.1016/j.riob.2011.09.005

Haddoud, M. Y., Jones, P., \& Newbery, R. (2017). Export promotion programmes and SMEs' performance: Exploring the network promotion role. Journal of Small Business and Enterprise Development, 24(1), 68-87. 
https://doi.org/10.1108/JSBED-07-2016-0116

Hair, J. F., Black, W. C., Babin, B. J., \& Anderson, R. E. (2010). Multivariate data analysis (7th ed.). Upper Saddle River: Pearson.

Harms, R., \& Schiele, H. (2012). Antecedents and consequences of effectuation and causation in the international new venture creation process. Journal of International Entrepreneurship, 10(2), 95-116. https://doi.org/10.1007/s10843012-0089-2

Hayton, J., Chandler, G. N., \& DeTienne, D. R. (2011). Entrepreneurial opportunity identification and new firm development processes: a comparison of family and non-family new ventures. International Journal of Entrepreneurship and Innovation Management, 13(1), 12. https://doi.org/10.1504/IJEIM.2011.038445

He, X., \& Cui, L. (2012). Can strong home country institutions foster the internationalization of MNEs? Multinational Business Review, 20(4), 352-375. https://doi.org/10.1108/15253831211286264

Herstad, S. J., \& Ebersberger, B. (2015). On the Link between Urban Location and the Involvement of Knowledge-Intensive Business Services Firms in Collaboration Networks. Regional Studies, 49(7), 1160-1175. https://doi.org/10.1080/00343404.2013.816413

Hervas-Oliver, J. L., Sempere-Ripoll, F., Rojas Alvarado, R., \& Estelles-Miguel, S. (2018). Agglomerations and firm performance: who benefits and how much? Regional Studies, 52(3), 338-349. https://doi.org/10.1080/00343404.2017.1297895

Hiatt, S. R., \& Sine, W. D. (2014). Clear and present danger: Planning and new venture survival amid political and civil violence. Strategic Management Journal, 35, 773-785. https://doi.org/10.1002/smj

Hilmersson, M., \& Jansson, H. (2012). International network extension processes to institutionally different markets: Entry nodes and processes of exporting SMEs. International Business Review, 21(4), 682-693. https://doi.org/10.1016/j.ibusrev.2011.08.003

Hite, J. M., \& Hesterly, W. S. (2001). The evolution of firm networks: From emergence to early growth of the firm. Strategic Management Journal, 22(3), 275-286. https://doi.org/10.1002/smj.156

Hitt, M. A., Li, H., \& Iv, W. J. W. (2005). Emerging Markets as Learning Laboratories: Learning Behaviors of Local Firms and Foreign The Internationalization of Chinese Firms : A Case for Theoretical Extension? John Child and Suzana B . Rodrigues. Management and Organization Review, 1(3), 353-380.

Johanson, J., \& Vahlne, J. E. (1977). The internationalization process of the firm: A model knowledge development and increasing foreign market commitments. Journal of International Business Studies, 8(1), 23-32. https://doi.org/10.2307/254397 
Johanson, J., \& Vahlne, J. E. (2006). Commitment and Opportunity Development in the Internationalization Process: A Note on the Uppsala Internationalization Process Model. Management International Review, 46(2), 165-178.

Johanson, J., \& Vahlne, J. E. (2009). The Uppsala internationalization process model revisited: From liability of foreignness to liability of outsidership. Journal of International Business Studies, 40(9), 1411-1431. https://doi.org/10.1057/jibs.2009.24

Jones, G. (2012). The Growth Opportunity That Lies Next Door. Harvard Business Review, (July-August), 1-11.

Jones, M.V. and Coviello, N.E. (2005) 'Internationalisation: conceptualising an entrepreneurial process of behaviour in time', Journal of International Business Studies, Vol. 36, No. 3, pp.284-303.

Jones, M. V, Coviello, N. E., \& Tang, Y. K. (2011). International Entrepreneurship research (1989-2009): A domain ontology and thematic analysis. Journal of Business Venturing, 26(6), 632-659. https://doi.org/10.1016/j.jbusvent.2011.04.001

Julian, C. C., \& Ahmed, Z. U. (2005). The impact of barriers to export on export marketing performance. Journal of Global Marketing, 19(1), 71-94. https://doi.org/10.1300/J042v19n01_05

Kalinic, I., Sarasvathy, S. D., \& Forza, C. (2014). "Expect the unexpected": Implications of effectual logic on the internationalization process. International Business Review, 23(3), 635-647. https://doi.org/10.1016/j.ibusrev.2013.11.004

Kallmuenzer, A., Hora, W. and Peters, M. (2018) 'Strategic decision-making in family firms: an explorative study', European Journal of International Management, Vol. 12, No. 5/6, pp.655-675. Available online at: https://doi.org/10.1504/ejim.2018.10014765

Karami, M., Wooliscroft, B., \& Mcneill, L. (2019). Effectuation and internationalisation: a review and agenda for future research. Small Business Economics.

Kaur, S., \& Sandhu, M. S. (2014). Internationalisation of born global firms: Evidence from Malaysia. Journal of the Asia Pacific Economy, 19(1), 101-136. https://doi.org/10.1080/13547860.2013.818426

Keng, K. A., \& Jiuan, T. S. (1989). Differences between Small and Medium Sized Exporting and Non-Exporting Firms: Nature or Nurture. International Marketing Review, 6(1).

Kerr, J., \& Coviello, N. (2019). Formation and Constitution of Effectual Networks: A Systematic Review and Synthesis. International Journal of Management Reviews, 21(3), 1-28. https://doi.org/10.1111/ijmr.12194

Keupp, M.M. and Gassmann, O. (2009) 'The past and the future of international 
entrepreneurship: a review and suggestions for developing the field', Journal of Management, Vol. 35, No. 3, pp.600-633. Available online at: http://doi.org/10.1177/0149206308330558

Khanna, T., \& Palepu, K. (2000). The Future of Business Groups in Emerging Markets: Long-Run Evidence from Chile. The Academy of Management Journal, 43(3), 268-285.

Khanna, T., \& Palepu, K. G. (2010). Winning in Emerging Markets : A Road Map for Strategy and Execution. Boston, MA: Harvard Business School Press. https://doi.org/10.1177/0974173920100316

Khanna, T., Palepu, K. G., \& Sinha, J. (2005). Strategies that fit emerging markets. Harvard Business Review, 83(6), 63-74. Retrieved from http://www.ncbi.nlm.nih.gov/pubmed/15938439

Kiss, A. N., \& Danis, W. M. (2008). Country institutional context, social networks, and new venture internationalization speed. European Management Journal, 26(6), 388-399. https://doi.org/10.1016/j.emj.2008.09.001

Knight, G. A., \& Cavusgil, S. T. (2004). Innovation, organizational capabilities, and the born-global firm. Journal of International Business Studies, 35(2), 124-141. https://doi.org/10.1057/palgrave.jibs.8400071

Knight, G. A., \& Liesch, P. W. (2016). Internationalization: From incremental to born global. Journal of World Business, 51(1), 93-102. https://doi.org/10.1016/j.jwb.2015.08.011

Kontinen, T., \& Ojala, A. (2011). Network ties in the international opportunity recognition of family SMEs. International Business Review, 20(4), 440-453. https://doi.org/10.1016/j.ibusrev.2010.08.002

Krammer, S. M. S., Strange, R., \& Lashitew, A. (2018). The export performance of emerging economy firms: The influence of firm capabilities and institutional environments. International Business Review, 27(1), 218-230. https://doi.org/10.1016/j.ibusrev.2017.07.003

Kuivalainen, O., Saarenketo, S., \& Puumalainen, K. (2012). Start-up patterns of internationalization: A framework and its application in the context of knowledge-intensive SMEs. European Management Journal, 30(4), 372-385. https://doi.org/10.1016/j.emj.2012.01.001

Kuivalainen, O., Sundqvist, S., \& Servais, P. (2007). Firms' degree of bornglobalness, international entrepreneurial orientation and export performance. Journal of World Business, 42(3), 253-267. https://doi.org/10.1016/j.jwb.2007.04.010

Kujala, I., \& Törnroos, J. Å. (2018). Internationalizing through networks from emerging to developed markets with a case study from Ghana to the U.S.A. Industrial Marketing Management, 69(February), 98-109. https://doi.org/10.1016/j.indmarman.2018.01.015 
Kyvik, O., Saris, W., Bonet, E., \& Felício, J. A. (2013). The internationalization of small firms: The relationship between the global mindset and firms' internationalization behavior. Journal of International Entrepreneurship, 11(2), 172-195. https://doi.org/10.1007/s10843-013-0105-1

Lages, L. F., \& Montgomery, D. B. (2004). Export performance as an antecedent of export commitment and marketing strategy adaptation: Evidence from small and medium-sized exporters. European Journal of Marketing, 238(9/10), 11861214. https://doi.org/https:// doi.org/10.1108/03090560410548933

Laine, I., \& Galkina, T. (2017). The interplay of effectuation and causation in decision making: Russian SMEs under institutional uncertainty. International Entrepreneurship and Management Journal, 13(3), 905-941. https://doi.org/10.1007/s11365-016-0423-6

Leeuwen, T. Van. (2006). The application of bibliometric analyses in the evaluation of social science research. Who benefits from it, and why it is still feasible. Scientometrics, 66(1), 133-154.

Leppäaho, T., Chetty, S., \& Dimitratos, P. (2018). Network embeddedness in the internationalization of biotechnology entrepreneurs. Entrepreneurship \& Regional Development, 30(5-6), 562-584. https://doi.org/10.1080/08985626.2017.1408697

Levitsky, S., \& Murillo, M. V. (2013). Building Institutions on Weak Foundations. Journal of Democracy, 24(2), 93-107.

Lingelbach, D., Sriram, V., Mersha, T., \& Saffu, K. (2015). The innovation process in emerging economies: An effectuation perspective. International Journal of Entrepreneurship and Innovation, 16(1), 5-17. https://doi.org/10.5367/ijei.2015.0172

Lukas, B. A., Whitwell, G. J., \& Hill, P. (2007). Export planning orientation and its antecedents: Evidence from exporting IT products. Journal of Business Research, 60(12), 1282-1289. https://doi.org/10.1016/j.jbusres.2007.05.002

Luo, Y., Xue, Q., \& Han, B. (2010). How emerging market governments promote outward FDI: Experience from China. Journal of World Business, 45(1), 68-79. https://doi.org/10.1016/j.jwb.2009.04.003

Madsen, T. K. (2013). Early and rapidly internationalizing ventures: Similarities and differences between classifications based on the original international new venture and born global literatures. Journal of International Entrepreneurship, 11(1), 65-79. https://doi.org/10.1007/s10843-012-0099-0

Mair, J., \& Marti, I. (2009). Entrepreneurship in and around institutional voids: A case study from Bangladesh. Journal of Business Venturing, 24(5), 419-435. https://doi.org/10.1016/j.jbusvent.2008.04.006

Mair, J., Martí, I., \& Ventresca, M. J. (2012). Building inclusive markets in rural Bangladesh: How intermediaries work institutional voids. Academy of 
Management Journal, 55(4), 819-850. https://doi.org/10.5465/amj.2010.0627

Manolova, T. S., Manev, I. M., \& Gyoshev, B. S. (2010). In good company: The role of personal and inter-firm networks for new-venture internationalization in a transition economy. Journal of World Business, 45(3), 257-265. https://doi.org/10.1016/j.jwb.2009.09.004

Martínez, M.A., Herrera, M., López-Gijón, J. and Herrera-Viedma, E. (2014) 'HClassics: characterizing the concept of citation classics through $\mathrm{H}$-index', Scientometrics, Vol. 98, No. 3, pp.1971-1983. Available online at: http://doi.org/10.1007/s11192-013-1155-9

Matalamäki, M. J. (2017). Effectuation, an emerging theory of entrepreneurship towards a mature stage of the development. Journal of Small Business and Enterprise Development, 24(4), 928-949. https://doi.org/https://doi.org/10.1108/JSBED-02-2017-0030

Matteis, P., Pietrovito, F., \& Pozzolo, A. F. (2019). Local context and exports: an analysis with a matched sample of firm-province data. Regional Studies, 53(4), 550-561. https://doi.org/10.1080/00343404.2018.1462482

McCann, B. T., \& Folta, T. B. (2011). Performance differentials within geographic clusters. Journal of Business Venturing, 26(1), 104-123. https://doi.org/10.1016/j.jbusvent.2009.04.004

McDougall, P.P. (1989) 'International versus domestic entrepreneurship: new venture strategic behavior and industry structure', Journal of Business Venturing, Vol. 4, No. 6, pp.387-400.

McDougall, P.P., Shane, S. and Oviatt, B.M. (1994) 'Explaining the formation of international new ventures: the limits of theories from international business research', Journal of Business Venturing, Vol. 9, No. 6, pp.469-487.

Merigó, M. and Urbano, D. (2016) Academic research in innovation : a country analysis. Available online at: http://doi.org/10.1007/s11192-016-1984-4.

Meliciani, V., \& Savona, M. (2015). The determinants of regional specialisation in business services: Agglomeration economies, vertical linkages and innovation. Journal of Economic Geography, 15(2), 387-416. https://doi.org/10.1093/jeg/lbt038

Mesquita, L. F., \& Lazzarini, S. G. (2008). Horizontal and Vertical Relationships in Developing Economies: Implications for SMEs' Access to Global Markets. Academy of Management Journal, 51(2), 359-380. https://doi.org/10.1007/9783-642-34289-9_70

Milanov, H., \& Fernhaber, S. A. (2014). When do domestic alliances help ventures abroad? Direct and moderating effects from a learning perspective. Journal of Business Venturing, 29(3),

377-391. https://doi.org/10.1016/j.jbusvent.2013.05.004

Miles, M., Huberman, A. and Saldaña, J. (1994) 'Designing matrix and network 
displays', Qualitative Data Analysis A Methods Sourcebook. Available online at: http://doi.org/10.1136/ebnurs.2011.100352

Mittelstaedt, J. D., Ward, W. A., \& Nowlin, E. (2006). Location, industrial concentration and the propensity of small US firms to export: Entrepreneurship in the international marketplace. International Marketing Review, 23(5), 486503. https://doi.org/10.1108/02651330610703418

Molina-Morales, F. X., Belso-Martínez, J. A., \& Más-Verdú, F. (2015). Formation and dissolution of inter-firm linkages in lengthy and stable networks in clusters. Journal of Business Research, 68, 1557-1562. https://doi.org/10.1016/j.jbusres.2015.01.051

Montoro-Sanchez, A., Diez-Vial, I., \& Belso-Martínez, J. A. (2018). The evolution of the domestic network configuration as a driver of international relationships in SMEs. International Business Review, (in press). https://doi.org/10.1016/j.ibusrev.2017.08.003

Mort, G.S., Weerawardena, J. and Liesch, P. (2012) 'Advancing entrepreneurial marketing: evidence from born global firms', European Journal of Marketing, Vol. 46, No. 3/4, pp.542-561. Available online at: http://doi.org/10.1108/03090561211202602

Mrvar, A. and Batagelj, V. (2016) 'Analysis and visualization of large networks with program package Pajek', Complex Adaptive Systems Modeling. Available online at: http://doi.org/10.1186/s40294-016-0017-8

Narooz, R., \& Child, J. (2017). Networking responses to different levels of institutional void: A comparison of internationalizing SMEs in Egypt and the UK. International Business Review, 26(4), 683-696. https://doi.org/10.1016/j.ibusrev.2016.12.008

Nemkova, E. (2017) 'The impact of agility on the market performance of born-global firms: an exploratory study of the "Tech City" innovation cluster', Journal of Business Research, Vol. 80 (November 2016), pp.257-265. Available online at: http://doi.org/10.1016/j.jbusres.2017.04.017

North, D., \& Smallbone, D. (2000). The innovativeness and growth of rural SMEs during the 1990s. Regional Studies, 34(2), 145-157. https://doi.org/10.1080/00343400050006069

Nowiński, W. and Rialp, A. (2013) 'Drivers and strategies of international new ventures from a Central European transition economy', Journal of East European Management Studies, Vol. 18, No. 2, pp.191-231.

Nummela, N., Saarenketo, S., Jokela, P., \& Loane, S. (2014). Strategic DecisionMaking of a Born Global: A Comparative Study From Three Small Open Economies. Management International Review, 54(4), 527-550. https://doi.org/10.1007/s11575-014-0211-x

Oviatt, B. M., \& McDougal, P. P. (1994). Toward a Theory of International New 
ventures. Journal of International Business Studies, 25(1), 45-64.

Oviatt, B. M., \& McDougal, P. P. (2005). Defining international entrepreneurship and modeling the speed of internationalization. Entrepreneurship: Theory and Practice, 29(5), 537-553. https://doi.org/10.1111/j.1540-6520.2005.00097.x

Pawęta, E. (2016). The Effectual Approach in Born Global Firms-Literature Review of the Current State of Research. Entrepreneurial Business and Economics Review, 4(2), 105-115. Retrieved from https://www.ceeol.com/search/articledetail $\mathrm{id}=411243$

Prashantham, S., \& Birkinshaw, J. (2015). Choose Your Friends Carefully: HomeCountry Ties and New Venture Internationalization. Management International Review, 55(2), 207-234. https://doi.org/10.1007/s11575-015-0244-9

Peiris, I.K., Akoorie, M.E.M. and Sinha, P. (2012) 'International entrepreneurship: a critical analysis of studies in the past two decades and future directions for research', Journal of International Entrepreneurship. Available online at: http://doi.org/10.1007/s10843-012-0096-3

Perry, J.T., Chandler, G.N. and Markova, G. (2011) 'Entrepreneurial effectuation: a review and suggestions for future research', Entrepreneurship: Theory \& Practice, Vol. 36, No. 4, pp.837-861. Available online at: http://doi.org/10.1111/j.1540-6520.2010.00435.x

Persson, O., Danell, R. and Schneider, J.W. (2009) 'How to use Bibexcel for various types of bibliometric analysis', in Åström, F., Danell, R., Larsen, B. and Schneider, J.W. (Eds): Celebrating Scholarly Communication Studies: A Festschrift for Olle Persson at his $60^{\text {th }}$ Birthday, International Society for Scientometrics and Informetrics, pp. 9-24.

Peters, H.P.F. and Raan, T.V. (1991) 'Structuring scientific activities by co-author analysis', Scientometrics, Vol. 20, No. 1, pp.235-255. Available online at: http://doi.org/10.1007/BF02018157

Prashantham, S., Kumar, K., Bhagavatula, S., \& Sarasvathy, S. D. (2019). Effectuation, network-building and internationalisation speed. International Small Business Journal: Researching Entrepreneurship, 37(1), 3-21. https://doi.org/10.1177/0266242618796145

Read, S., Dew, N., Sarasvathy, S. D., Song, M., \& Wiltbank, R. (2009). Marketing Under Uncertainty: The Logic of an Effectual Approach. Journal of Marketing, 73(3), 1-18.

Read, S., Sarasvathy, S. D., Dew, N., \& Robert, W. (2016). Straw Man At Sea: Positivist Critique of a Pragmatist Theory. Academy of Management Perspectives, 41(3), 528-536. https://doi.org/10.5465/amr.2015.0180

Reid, S. (1983) 'Firm internationalization, transaction costs and strategic choice', International Marketing Review, Vol. 1, No. 2, pp.44-56.

Reuber, A. R., Fischer, E., \& Coviello, N. (2016). Deepening the Dialogue: New 
Directions for the Evolution of Effectuation Theory. Academy of Management Review, 41(3), 536-540.

Rialp, A. and Rialp, J. (2007) 'Faster and more successful exporters : an exploratory study of born global firms from the resource-based view', Journal of Euromarketing, Vol. 41, No. 6, pp.37-41. Available online at: http://doi.org/10.1300/J037v16n01

Rialp, A., Rialp, J., \& Knight, G. A. (2005). The phenomenon of early internationalizing firms: What do we know after a decade (1993-2003) of scientific inquiry? International Business Review, 14(2), 147-166. https://doi.org/10.1016/j.ibusrev.2004.04.006

Rihoux, B., \& Ragin, C. C. (2009). Configurational Comparative Methods: Qualitative Comparative Analysis (QCA) and Related Techniques. London: SAGE Publications. https://doi.org/http://dx.doi.org/10.4135/9781452226569

Rindfleisch, A., \& Moorman, C. (2001). The Acquisition and Utilization of Information in New Product Alliances: A Strength-of-Ties Perspective. Journal of Marketing, 65(2), 1-18. https://doi.org/10.1509/jmkg.65.2.1.18253

Ripollés, M. and Blesa, A. (2017) 'Entry mode choices in the international new ventures context. A study from different theoretical perspectives', International Entrepreneurship and Management Journal, Vol. 13, No. 2, pp.465-485. Available online at: http://doi.org/10.1007/s11365-016-0410-y

Robledo Giraldo, S., Osorio Zuluaga, G. A., \& López Espinosa, C. (2014). Networking en pequeña empresa: una revisión bibliográfica utilizando la teoría de grafos. Revista Vinculos, 11(6), 2014.

Ryan, P., Evers, N., Smith, A., \& Andersson, S. (2019). Local horizontal network membership for accelerated global market reach. International Marketing Review, 36(1), 6-30. https://doi.org/10.1108/IMR-03-2017-0061

Santangelo, G. D., \& Meyer, K. E. (2011). Extending the internationalization process model: Increases and decreases of MNE commitment in emerging economies. Journal of International Business Studies, 42(7), 894-909. https://doi.org/10.1057/jibs.2011.25

Sarasvathy, S. D. (2001). Toward Causation and Effectuation: A Theoritical Shift From Inevitability to Economic Entrepreneurial Contingency. The Academy of Management Review, 26(2), 243-263. https://doi.org/10.2307/259121

Sarasvathy, S. D. (2008). Effectuation: elements of entrepreneurial expertise. Cheltenham: Edward Elgar Publishing Limited.

Sarasvathy, S. D. (2009). Effectuation: Elements of Entrepreneurial Expertise. Cheltenham: Edward Elgar.

Sarasvathy, S. D., \& Dew, N. (2005). New market creation through transformation. Journal of Evolutionary Economics, 15(5), 533-565. https://doi.org/10.1007/s00191-005-0264-x 
Sarasvathy, S. D., Kumar, K., York, J. G., \& Bhagavatula, S. (2014). An Effectual Approach to International Entrepreneurship: Overlaps, Challenges, and Provocative Possibilities. Entrepreneurship Theory and Practice, 38(1), 71-93. https://doi.org/https://doi.org/10.1111/etap.12088

Saxenian, A. (1994). Regional Advantage: Culture and Competition in Silicon Valley and Route 128. Cambridge MA. Cambridge, MA: Harvard University Press.

Schweizer, R., Vahlne, J. E., \& Johanson, J. (2010). Internationalization as an entrepreneurial process. Journal of International Entrepreneurship, 8(4), 343370. https://doi.org/10.1007/s10843-010-0064-8

Schwens, C., \& Kabst, R. (2011). Internationalization of young technology firms: A complementary perspective on antecedents of foreign market familiarity. International Business Review, 20(1), 60-74. https://doi.org/10.1016/j.ibusrev.2010.06.003

Scott, W. R. (2014). Institutions and Organizations Ideas, Interests, and Identities (4th ed.). SAGE.

Servantie, V., \& Rispal, M. H. (2018). Bricolage, effectuation, and causation shifts over time in the context of social entrepreneurship. Entrepreneurship and Regional Development, 30(3-4), 310-335. https://doi.org/10.1080/08985626.2017.1413774

Sharma, P. (2011). Country-of-origin effects in developed vs. emerging markets: Exploring the contrasting roles of materialism and value-consciousness. Journal of International Business Studies, 42(2), 285-306. https://doi.org/10.1057/jibs.2010.16

Shearmur, R., \& Doloreux, D. (2008). Urban hierarchy or local buzz? high-order producer service and (or) knowledge-intensive business service location in Canada, 1991-2001. Professional Geographer, 60(3), 333-355. https://doi.org/10.1080/00330120801985661

Söderqvist, A., \& Chetty, S. (2013). Strength of ties involved in international new ventures. European Business Review, 25(6), 536-552. https://doi.org/10.1108/EBR-03-2013-0034

Spence, M., \& Crick, D. (2006). A comparative investigation into the internationalisation of Canadian and UK high-tech SMEs. International Marketing Review, 23(5), 524-548. https://doi.org/https://doi.org/10.1108/02651330610703436

Spence, M., Orser, B., \& Riding, A. (2011). A comparative study of international and domestic new ventures. Management International Review, 51(1), 3-21. https://doi.org/10.1007/s11575-010-0065-9

Srivastava, M., Moser, R., \& Hartmann, E. (2018). The networking behavior of Indian executives under environmental uncertainty abroad: An exploratory analysis. Journal of Business Research, 82(September 2016), 230-245. 
https://doi.org/10.1016/j.jbusres.2017.09.036

Stephan, U., Uhlaner, L. M., \& Stride, C. (2015). Institutions and social entrepreneurship: The role of institutional voids, institutional support, and institutional configurations. Journal of International Business Studies, 46(3), 308-331. https://doi.org/10.1057/jibs.2014.38

Su, J., Zhai, Q., \& Karlsson, T. (2017). Beyond Red Tape and Fools: Institutional Theory in Entrepreneurship Research, 1992-2014. Entrepreneurship: Theory and Practice, 41(4), 505-531. https://doi.org/10.1111/etap.12218

Tang, J., Tang, Z., \& Katz, J. A. (2014). Proactiveness, Stakeholder-Firm Power Difference, and Product Safety and Quality of Chinese SMEs. Entrepreneurship: Theory and Practice, 38(5), 1129-1157. https://doi.org/10.1111/etap.12029

Teece, D.J., Pisano, G. and Shuen, A. (1997) 'Dynamic capabilities and strategic management', Strategic Management Journal, Vol. 18, No. 7, pp.509-533. Available online at: http://doi.org/10.1016/B978-0-7506-7088-3.50009-7

Torkkeli, L., \& Fuerst, S. (2018). Country institutional profiles: evidence from Colombian software exporters. Academia Revista Latinoamericana de Administración, 31(4), 663-678. https://doi.org/10.1108/ARLA-09-2015-0253

Torkkeli, L., Kuivalainen, O., Saarenketo, S., \& Puumalainen, K. (2019). Institutional environment and network competence in successful SME internationalisation. International Marketing Review, 36(1), 31-55.

Uzzi, B. (1997). Social Structure and Competition in Interfirm Networks: The Paradox of Embeddedness. Administrative Science Quarterly, 42(1), 35. https://doi.org/10.2307/2393808

Vaessen, P., \& Keeble, D. (1995). Growth-oriented SMEs in Unfavourable Regional Environments. Regional Studies, 29(6), 489-505. https://doi.org/10.1080/00343409512331349133

Vahlne, J. E., \& Johanson, J. (2017). From internationalization to evolution: The Uppsala model at 40 years. Journal of International Business Studies, 1, 1-16. https://doi.org/10.1057/s41267-017-0107-7

Van Eck, N.J. and Waltman, L. (2010) 'Software survey : VOSviewer , a computer program for bibliometric mapping', Scientometrics, Vol. 84, No. 2, pp.523-538. Available online at: http://doi.org/10.1007/s11192-009-0146-3

Van Eck, N.J. and Waltman, L. (2014) 'Visualizing bibliometric networks', in Ding, Y., Rousseau, R. and Wolfram, D. (Eds): Measuring Scholarly Impact: Methods and Practice, Springer International Publishing, pp. 285-320. Available online at: https://doi.org/10.1007/978-3-319-10377-8

Vassolo, R. S., De Castro, J. O., \& Gomez-Mejia, L. R. (2011). Managing in Latin America: Common issues and a research agenda. Academy of Management Perspectives, 25(4), 22-36. https://doi.org/10.5465/amp.2011.0129 
Verreynne, M., Meyer, D., \& Liesch, P. (2016). Beyond the Formal - Informal Dichotomy of Small Firm Strategy-Making in Stable and Dynamic Environments. Journal of Small Business Management, 54(2), 420-444. https://doi.org/10.1111/jsbm.12143

Volchek, D., Henttonen, K., \& Edelmann, J. (2013). Exploring the Role of a Country's Institutional Environment in Internationalization: Strategic Responses of SMEs in Russia. Journal of East-West Business, 19(4), 317-350. https://doi.org/10.1080/10669868.2013.851140

Weerawardena, J., Mort, G. S., Liesch, P. W., \& Knight, G. A. (2007). Conceptualizing accelerated internationalization in the born global firm: A dynamic capabilities perspective. Journal of World Business, 42(3), 294-306. https://doi.org/10.1016/j.jwb.2007.04.004

Wernerfelt, B. (1984) 'A resource-based view of the firm', Strategic Management Journal, Vol. 5, No. 2, pp.171-180. Available online at: http://doi.org/10.1002/smj.4250050207

Westhead, P., Ucbasaran, D., \& Binks, M. (2004). Internationalization strategies selected by established rural and urban SMEs. Journal of Small Business and Enterprise Development, 11(1), 8-22. https://doi.org/10.1108/14626000410519065

Westhead, P., Wright, M., \& Ucbasaran, D. (2001). The internationalization of new and small firms: a resource-based view. Journal of Business Venturing, 16(4), 333-358. https://doi.org/10.1016/S0883-9026(99)00063-4

Wilson, J. S., Mann, C. L., \& Otsuki, T. (2005). Assessing the potential benefit of trade facilitation: A global perspective. Quantitative Methods for Assessing the Effects of Non-Tariff Measures and Trade Facilitation, 121-160. https://doi.org/10.1142/9789812701350_0008

Wiltbank, R. E., \& Sarasvathy, S. D. (2010). What Effectuation is Not: Further Development of an Alternative to Rational Choice. Academy of Management Conference, (August), $40 . \quad$ Retrieved from http://www.effectuation.org/sites/default/files/research_papers/noteffectuation.pdf

Witt, M. A., \& Lewin, A. Y. (2007). Outward Foreign Direct Investment as Escape Response to Home Country Institutional Constraints. Journal of International Business Studies, 38(4), 579-594.

Woodside, A. G. (2013). Moving beyond multiple regression analysis to algorithms: Calling for adoption of a paradigm shift from symmetric to asymmetric thinking in data analysis and crafting theory. Journal of Business Research, 66(4), 463472. https://doi.org/10.1016/j.jbusres.2012.12.021

Wright, M., Westhead, P., \& Ucbasaran, D. (2007). Internationalization of small and medium-sized enterprises (SMEs) and international entrepreneurship: A critique and policy implications. Regional Studies, 41(7), 1013-1030. 
https://doi.org/10.1080/00343400601120288

Wu, C. W. (2016). Global entrepreneurship and innovation in management: Comparing MRA/SEM versus fuzzy-set QCA theory creation, data analysis, and findings. Journal of Business Research, 69(6), 2061-2066. https://doi.org/10.1016/j.jbusres.2015.12.009

Xiao, H., Wang, Y., Li, W., \& Ma, Z. (2017). Institutional contexts, institutional capability and accelerated internationalization of entrepreneurial firms from emerging economies. Nankai Business Review International, 8(1), 100-120. https://doi.org/10.1108/NBRI-10-2016-0035

Xu, Z., Lin, J., \& Lin, D. (2008). Networking and innovation in SMEs: evidence from Guangdong Province, China. Journal of Small Business and Enterprise Development, 15(4), 788-801. https://doi.org/10.1108/14626000810917861

Yang, M. and Gabrielsson, P. (2017) 'Entrepreneurial marketing of international high-tech business-to-business new ventures: a decision-making process perspective', Industrial Marketing Management, Vol. 64, pp.147-160. Available online at: http://doi.org/10.1016/j.indmarman.2017.01.007

Yamakawa, Y., Peng, M. W., \& Deeds, D. L. (2008). What Drives New Ventures to Internationalize from Emerging to Developed Economies? Entrepreneurship: Theory and Practice, 32(1), 59-82.

Yeung, H. W. C. (2009). Transnationalizing entrepreneurship: A critical agenda for economic geography. Progress in Human Geography, 33(2), 210-235. https://doi.org/10.1177/0309132508096032

Yi, J., Wang, C., \& Kafouros, M. (2013). The effects of innovative capabilities on exporting: Do institutional forces matter? International Business Review, 22(2), 392-406. https://doi.org/10.1016/j.ibusrev.2012.05.006

Yin, R. K. (2003). Case Study Research: Design and Methods. (Sage, Ed.). California: Thousand Oaks.

Yu, D., \& Shi, S. (2015). Researching the development of Atanassov intuitionistic fuzzy set: Applied Soft Computing Journal, 1-10. https://doi.org/10.1016/j.asoc.2015.03.027

Zahra, S. A., \& George, G. (2002). International entrepreneurship: the current status of the field and future research agenda. In S. D. Hitt MA, Ireland RD, Camp SM (Ed.), Strategic entrepreneurship: Creating a new mindset (pp. 255-288). Oxford: Blackwell. https://doi.org/10.1111/b.9780631234104.2002.00012.x

Zupic, I. and Čater, T. (2015) 'Bibliometric methods in management and organization', Organizational Research Methods, Vol. 18, No. 3, pp.429-472. Available online at: http://doi.org/10.1177/1094428114562629 
